\title{
38. BONINITE AND HARZBURGITE FROM LEG 125 (BONIN-MARIANA FOREARC): A CASE STUDY OF MAGMA GENESIS DURING THE INITIAL STAGES OF SUBDUCTION ${ }^{1}$
}

\author{
Julian A. Pearce, ${ }^{2}$ Sieger R. van der Laan, ${ }^{3}$ Richard J. Arculus, ${ }^{4}$ Bramley J. Murton, ${ }^{2.5}$ Teruaki Ishii, ${ }^{6}$ David W. Peate, ${ }^{2}$ \\ and Ian J. Parkinson ${ }^{2}$
}

\begin{abstract}
Holes drilled into the volcanic and ultrabasic basement of the Izu-Ogasawara and Mariana forearc terranes during Leg 125 provide data on some of the earliest lithosphere created after the start of Eocene subduction in the Western Pacific. The volcanic basement contains three boninite series and one tholeiite series. (1) Eocene low-Ca boninite and low-Ca bronzite andesite pillow lavas and dikes dominate the lowermost part of the deep crustal section through the outer-arc high at Site 786. (2) Eocene intermediate-Ca boninite and its fractionation products (bronzite andesite, andesite, dacite, and rhyolite) make up the main part of the boninitic edifice at Site 786. (3) Early Oligocene intermediate-Ca to high-Ca boninite sills or dikes intrude the edifice and perhaps feed an uppermost breccia unit at Site 786. (4) Eocene or Early Oligocene tholeiitic andesite, dacite, and rhyolite form the uppermost part of the outer-arc high at Site 782. All four groups can be explained by remelting above a subduction zone of oceanic mantle lithosphere that has been depleted by its previous episode of partial melting at an ocean ridge. We estimate that the average boninite source had lost $10-15 \mathrm{wt} \%$ of melt at the ridge before undergoing further melting (5-10\%) shortly after subduction started. The composition of the harzburgite ( $<2 \%$ clinopyroxene, Fo content of about $92 \%)$ indicates that it underwent a total of about $25 \%$ melting with respect to a fertile MORB mantle. The low concentration of $\mathrm{Nb}$ in the boninite indicates that the oceanic lithosphere prior to subduction was not enriched by any asthenospheric (OIB) component.

The subduction component is characterized by (1) high $\mathrm{Zr}$ and $\mathrm{Hf}$ contents relative to $\mathrm{Sm}$, Ti, Y, and middle-heavy REE, (2) light REE-enrichment, (3) low contents of $\mathrm{Nb}$ and $\mathrm{Ta}$ relative to $\mathrm{Th}$, $\mathrm{Rb}$, or $\mathrm{La}$, (4) high contents of $\mathrm{Na}$ and $\mathrm{Al}$, and (5) $\mathrm{Pb}$ isotopes on the Northern Hemisphere Reference Line. This component is unlike any subduction component from active arc volcanoes in the Izu-Mariana region or elsewhere. Modeling suggests that these characteristics fit a trondhjemitic melt from slab fusion in amphibolite facies. The resulting metasomatized mantle may have contained about $0.15 \mathrm{wt} \%$ water. The overall melting regime is constrained by experimental data to shallow depths and high temperatures $\left(1250^{\circ} \mathrm{C}\right.$ and $1.5 \mathrm{~kb}$ for an average boninite) of boninite segregation. We thus envisage that boninites were generated by decompression melting of a diapir of metasomatized residual MORB mantle leaving the harzburgites as the uppermost, most depleted residue from this second stage of melting. Thermal constraints require that both subducted lithosphere and overlying oceanic lithosphere of the mantle wedge be very young at the time of boninite genesis. This conclusion is consistent with models in which an active transform fault offsetting two ridge axes is placed under compression or transpression following the Eocene plate reorganization in the Pacific. Comparison between Leg 125 boninites and boninites and related rocks elsewhere in the Western Pacific highlights large regional differences in petrogenesis in terms of mantle mineralogy, degree of partial melting, composition of subduction components, and the nature of pre-subduction lithosphere. It is likely that, on a regional scale, the initiation of subduction involved subducted crust and lithospheric mantle wedge of a range of ages and compositions, as might be expected in this type of tectonic setting.
\end{abstract}

\section{INTRODUCTION}

During Leg 125, scientists drilled a series of holes at nine sites on the outer-arc high and inner trench wall of the Izu-Bonin (Ogasawara) and Mariana arc-trench systems. The basement at these sites formed mainly during the Eocene and early Oligocene in the initial stages of the present phase of subduction in the Western Pacific. The outer-arc high sites yielded crustal rocks, mainly of boninitic character. These are broadly similar to the subaerial exposures on the island of Chichijima in the Bonin Island group to the south, which is the type locality for boninite. The inner trench wall sites are on serpentinite seamounts containing clasts of serpentinized harzburgite. Petrologists generally accept that there is a causal relationship between boninite genesis and the initiation of subduction. They also believe the harzburgite to be the residue from the high degree of melting (in two or more stages) required for boninite genesis (e.g., Duncan and Green, 1987; Crawford,

1 Fryer, P., Pearce, J. A., Stokking, L. B., et al., 1992. Proc. ODP, Sci. Results, 125 : College Station, TX (Ocean Drilling Program).

${ }^{2}$ Department of Geological Sciences, University of Durham, Durham DH1 3LE, United Kingdom.

${ }^{3}$ Hawaii Institute of Geophysics, University of Hawaii at Manoa, 2525 Correa Rd., Honolulu, HI 96822, U.S.A.

${ }^{4}$ Department of Geology and Geophysics, University of New England, Armidale, N.S.W. 2351, Australia.

${ }_{5}^{5}$ Institute of Oceanographic Sciences, Godalming, Surrey GU8 5UB, United Kingdom.

${ }^{6}$ Ocean Research Institute, University of Tokyo, Minamidai, Nakano, Tokyo 164, Japan.
1989). The origin and tectonic significance of boninite is still poorly understood, however. Numerous models, not necessarily mutually exclusive, have been put forward for the genesis of boninites in the Western Pacific Eocene province. These include:

1. Partial melting of serpentinized harzburgite during initiation of subduction along a transform fault (Hawkins et al., 1984).

2. Multi-stage melting of the mantle, starting at a mid-ocean ridge and continuing above a subduction zone in response to addition of water or to extension (Duncan and Green, 1980, 1987).

3. Mantle melting associated with subduction beneath an active or dying oceanic ridge system (van der Laan, 1987) or beneath young, hot oceanic lithosphere (Sharaki et al., 1978; Meijer, 1980).

4. Partial melting of the mantle wedge in response to the subduction of young, hot oceanic lithosphere during the early stages of subduction (Tatsumi, 1982; Crawford et al., 1986).

5. Partial melting of the mantle wedge in response to the subduction of an active spreading center trending subparallel to an intraoceanic arc-trench system (Crawford et al., 1989).

6. Contact melting of the hydrous mantle wedge by injection of a hot mantle diapir during arc rifting (Crawford et al., 1986).

The rocks drilled during Leg 125 provide the basis for this detailed study of the petrogenesis and tectonic setting of formation of the boninitic lithosphere underlying the outer-arc high of the Izu-Ogasawara forearc. Most of our data come from Site 786, where $125 \mathrm{~m}$ of 
sediment and $701 \mathrm{~m}$ of basement were cored. Drilling at this site penetrated a complex edifice of Eocene to early Oligocene age predominantly made up of volcanic rocks and dikes of the boninite series. We also obtained important data from Site 782, which provided a small quantity of tholeiitic andesite, dacite and rhyolite, and from Sites 778-780 and 783-784, where serpentinized harzburgite was cored.

A series of detailed studies were conducted on the core from these sites. These include the lithostratigraphy and major element characteristics (Arculus et al., this volume); the mineralogy and phase relations of the volcanic rocks (van der Laan et al., this volume) and ultrabasic rocks (Ishii et al., this volume); the trace element geochemistry of the volcanic rocks (Murton et al., this volume) and ultrabasic rocks (Parkinson et al., this volume); the isotope systematics of the volcanic rocks (Pearce et al., this volume); the volatile content of volcanic glass (Newman and van der Laan, this volume); K-Ar dating (Mitchell et al., this volume); and structural studies of the volcanic edifice (Lagabrielle et al., this volume) and ultrabasic clasts in the serpentinite seamounts (Girardeau and Lagabrielle, this volume).

The aim of this chapter is: (1) to establish the setting of the Leg 125 sites in the context of the Eocene-Oligocene geology of the Western Pacific; (2) to summarize briefly the key results from the chapters cited above that relate to the tectonic setting and petrogenesis of the Izu-Bonin and Mariana outer forearcs; (3) to develop further the models generated by these studies for the origin of the lavas and dikes in relation to the initiation of subduction, using published melting experiments and thermal modeling of the subduction process; and (4) to compare the composition of the rocks from Leg 125 with compositions of similar rock types from other parts of the Eocene province.

\section{PRESENT-DAY SETTING OF LEG 125 BASEMENT SITES}

Figure 1 shows the present-day configuration of the arc-basin system south of Japan. The main features are (from east to west) (1) the Izu-Bonin-Mariana-Palau-Yap trench system, (2) the corresponding forearc terranes, (3) the actively-spreading Mariana back-arc basin and incipient back-arc rift basins of the Izu-Bonin system, (4) the West Mariana Ridge, a remnant arc, (5) the Parece Vela and Shikoku marginal basins, (6) the Palau-Kyushu Ridge, the westernmost remnant arc, and (7) the West Philippine Basin, a marginal basin that contains a series of bathymetric highs, the Amami-Oki-Daito province, in the north.

Although the details remain unresolved, there is general consensus on the principal events leading to the present-day configuration of these island arcs and marginal basins (e.g., Karig et al., 1978; Kobayashi and Nakada, 1979; Hussong and Uyeda, 1981). The early arc terrane, the subject of this chapter, mainly developed from the inception of subduction in the Eocene (between 48 and $43 \mathrm{Ma}$ ) through the early Oligocene (between 34 and $31 \mathrm{Ma}$ ). Spreading then began in the central Parece Vela Basin, propagating north and south and separating the Palau-Kyushu Ridge from the remainder of the early arc terrane. A further episode of spreading began at about $25 \mathrm{Ma}$ in what became the northern Shikoku Basin and propagated south so that the two systems had joined by about $23 \mathrm{Ma}$. These shared a common spreading axis until spreading ceased at 17-15 Ma. A subsequent cycle of rifting and back-arc spreading caused additional splitting of the southern part of the arc. After further arc volcanism, spreading in the Mariana Trough starting at about $6 \mathrm{Ma}$ isolated the West Mariana Ridge remnant arc. The Izu-Bonin arc is, by contrast, still in the rifting stage of back-arc development.

The Leg 125 sites are shown in more detail in maps and sections of Figures 2 and 3. Figure 2 shows the Izu-Bonin forearc sites, Sites $782-786$, of which all except Site 785 reached basement. A summary of the lithologies recovered at these sites is given in Table 1. Sites 782 and 786 penetrated the Oligocene-Eocene volcanic basement of the outer-arc high, whereas Sites 783 and 784 penetrated into the serpentinite mud and ultrabasic clasts of Torishima Forearc Seamount.
Also located in this figure are the sites drilled during Leg 126. Of direct relevance to this paper are Sites 792 and 793, which penetrated the Oligocene basement of the forearc basin.

Figure 3 shows the equivalent detailed map and section of the Mariana forearc. During Leg 125, three "basement" sites, Sites 778780 , were drilled on Conical Seamount in the outer Mariana forearc, retrieving ultrabasic rocks. No sites were drilled into Mariana volcanic basement during this leg, although this aim was achieved further south during DSDP Leg 60 at Sites 458-461, which lie just south of the map area and are located on the cross section.

\section{EOCENE-EARLY OLIGOCENE GEOLOGY OF THE WESTERNPACIFIC}

In this chapter we focus on the early arc evolution of the Western Pacific. To place the Leg 125 sites in context, we constructed in Figure 4 a geological map of the Western Pacific as it might have appeared in the early Oligocene before the early arc terrane rifted apart during the opening of the Parece Vela Basin. In doing this we took into account the rotations and translations of the system since that time, as reported by Louden (1977), McCabe and Uyeda (1983), Kodama et al. (1983), and others. We also removed the effects of collision with the Caroline Ridge, Ogasawara Plateau, and other edifices on the Pacific plate as well as the effect of subduction along the Ryukyu Trench. The map is highly schematic, having been produced by extrapolation from, and interpolation between, a small number of localities. These localities are all marked in Figures 1 and 4. A summary of their geology is given below.

1. The Izu-Bonin outer-arc high is probably made up of Eocene to Early Oligocene volcanic edifices. The edifice drilled at Site 786 during Leg 125 is made up of all members of a boninite series from boninite sensu stricto through bronzite andesite to andesite, dacite, and rhyolite. Its age is about $41 \mathrm{Ma}$, although it was intruded by a set of late boninite dikes or sills at about $35 \mathrm{Ma}$ (Mitchell et al., this volume). It lay close to sea level in the late stages of its construction. At Site 782, the outer-arc high is made up of tholeiitic andesite and dacite, evidence of along-strike petrological variations.

The outer arc high is subaerially exposed along the Ogasawara Ridge to form the Bonin (Ogasawara) islands. Mapping by Umino (1985), Maruyama and Kuramoto (1981), Dobson (1986), and others shows that it is made up of a series of boninitic volcanic edifices (Chichi-jima and most other islands) and one tholeiitic edifice (Hahajima). Chichi-jima, the largest island, has been divided into several formations: the Marubewan, which comprises pillowed and sheet flows, breccia and hyaloclastite of boninite, bronzite andesite, and, rarely, dacite composition; the Asahiyama, which comprises quartz dacite and rhyolite flows; and the Mikazukiyama, which comprises volcaniclastic sandstone and breccia. No consistent pattern of ages has emerged. A single Ar-Ar date from a boninite from the Murubewan Formation gives an age of 48.0 $\pm 0.5 \mathrm{Ma}$ (Dobson, 1986) and overlying sediments contain middle Eocene radiolarians. By contrast, boninite and dacite from the same formation give $\mathrm{K}$-Ar ages of 43-39 Ma and a two-pyroxene andesite gives a K-Ar age of $29 \mathrm{Ma}$ (Umino, 1985). Thus, either the glass used for Ar-Ar dating contained excess $\mathrm{Ar}$ or the $\mathrm{K}-\mathrm{Ar}$ age was reset by alteration. In view of the importance of these ages for dating the initiation of subduction, a further $\mathrm{Ar}-\mathrm{Ar}$ age was determined on a clinoenstatite-bearing lava collected from near the base of the edifice. The age obtained was $39 \pm 6$ Ma (J.A.P. and D. Rex, unpubl. data).

2. The Izu-Bonin forearc basin was recently shown by scientists on Leg 126 to have an Oligocene volcanic basement (Taylor, Fujioka, Janecek, et al., 1990). The basement at Site 792 is made up of massive porphyritic two-pyroxene andesite (with minor basalt and dacite) flows and intercalated hyaloclastite and breccia. The basement at Site 793 is made up of volcanic breccia with andesitic clasts overlying breccia and pillowed flows of basaltic andesite and andesite, mostly 


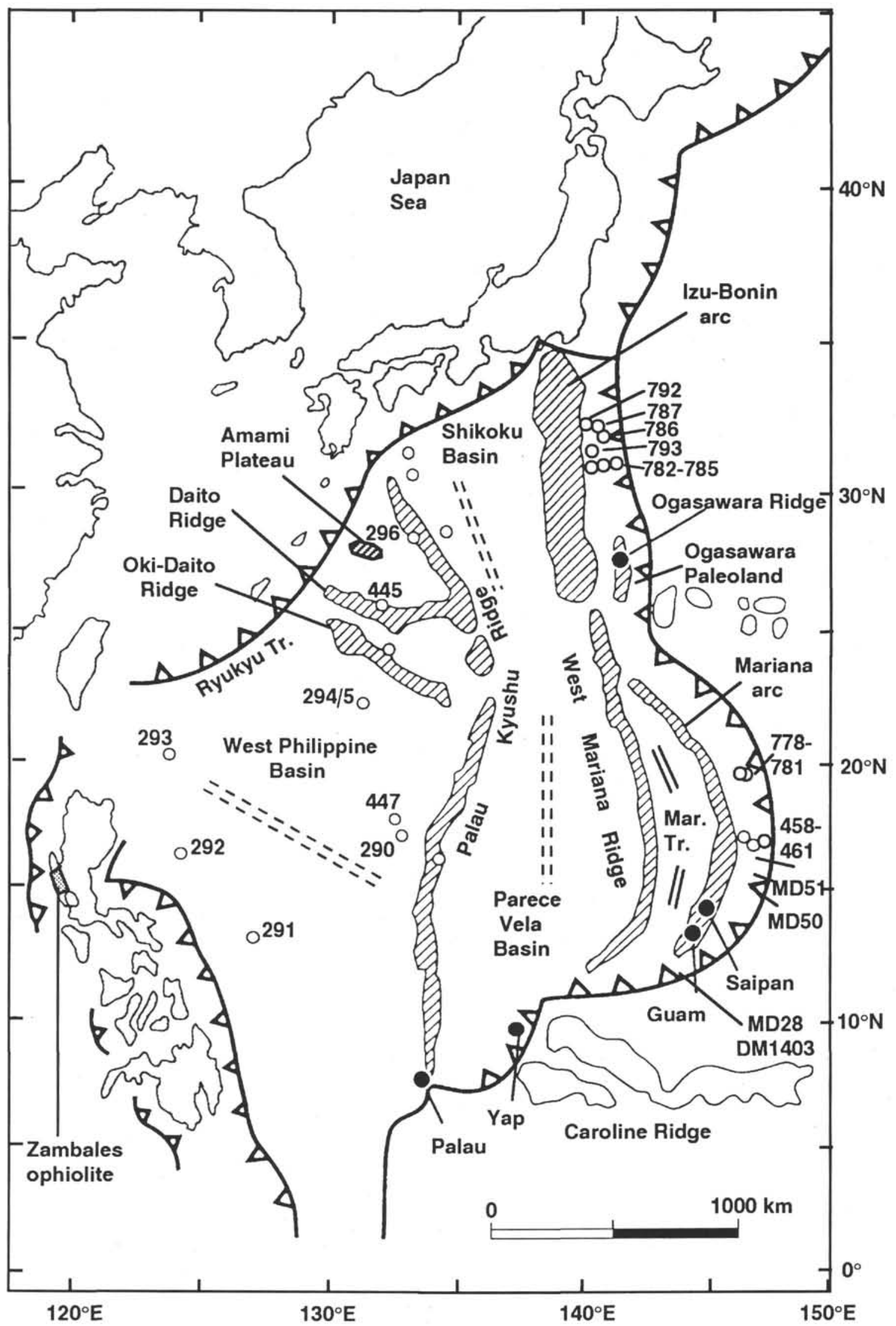

Figure 1. Regional setting of Leg 125 drill sites (Sites 778-786) and locations of the Eocene-Oligocene and other terranes, drill sites (open circles), and dredge sites discussed in the text. 

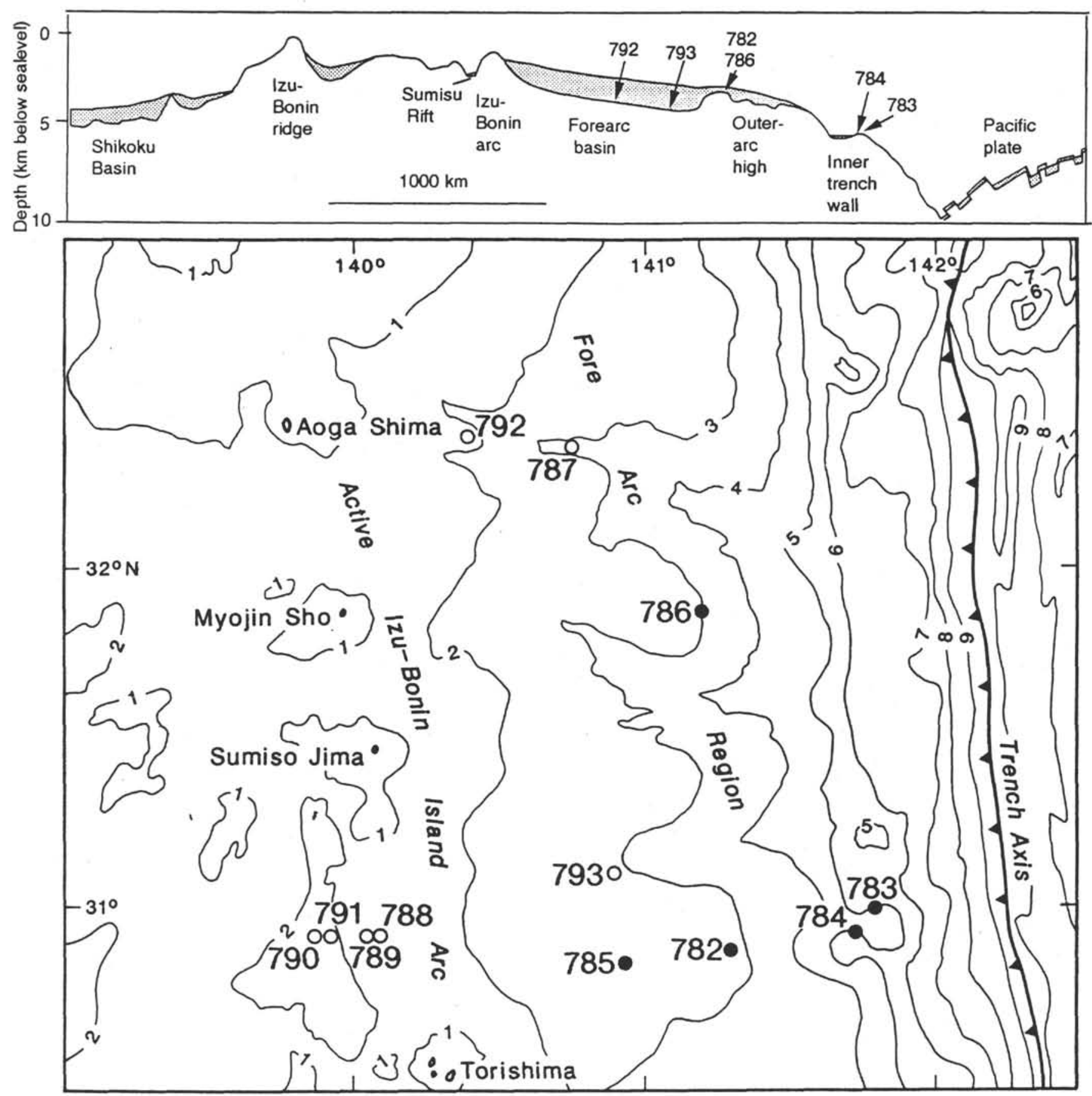

Figure 2. Oligocene-Eocene drill sites from Legs 125 (solid circles) and 126 (open circles) in the lzu-Ogasawara forearc as seen in plan view and schematic cross section. The cross section is taken from Honza and Tamaki (1985) from a latitude of approximately $31^{\circ} \mathrm{N}$.

with boninitic affinities. Although the center of this basin post-dates the reconstruction in Figure 4, extensional events related to the opening of the basin may have begun by the early Oligocene.

3. The Izu-Bonin inner trench wall has been extensively dredged around the Ogasawara Palaeoland (Ishii et al., 1981, 1983; Ishii, 1985), and drilled during Leg 125 at the Torishima Forearc Seamount (Fig. 1). Ishii (1985) argues that the harzburgite, dunite, gabbro, dolerite, and basalt of the Ogasawara Palaeoland are part of a section of oceanic lithosphere formed in a forearc setting. In his model, the harzburgite drilled on Torishima Forearc seamount represents the mantle sequence of this lithosphere, exposed some time after its formation by serpentinite diapirism or extension (or both) in the inner trench wall. Other rock types also have been recovered, however. These include boninitic series dacite (Johnson and Nakamura, 1985), probably derived from boninitic volcanoes similar to those forming the Ogasawara Ridge. They also include tholeiitic basalt, gabbro, and amphibolite (Ogawa et al., 1985), probably representing the lithosphere on which the forearc was built, fragments of accreted Pacific 

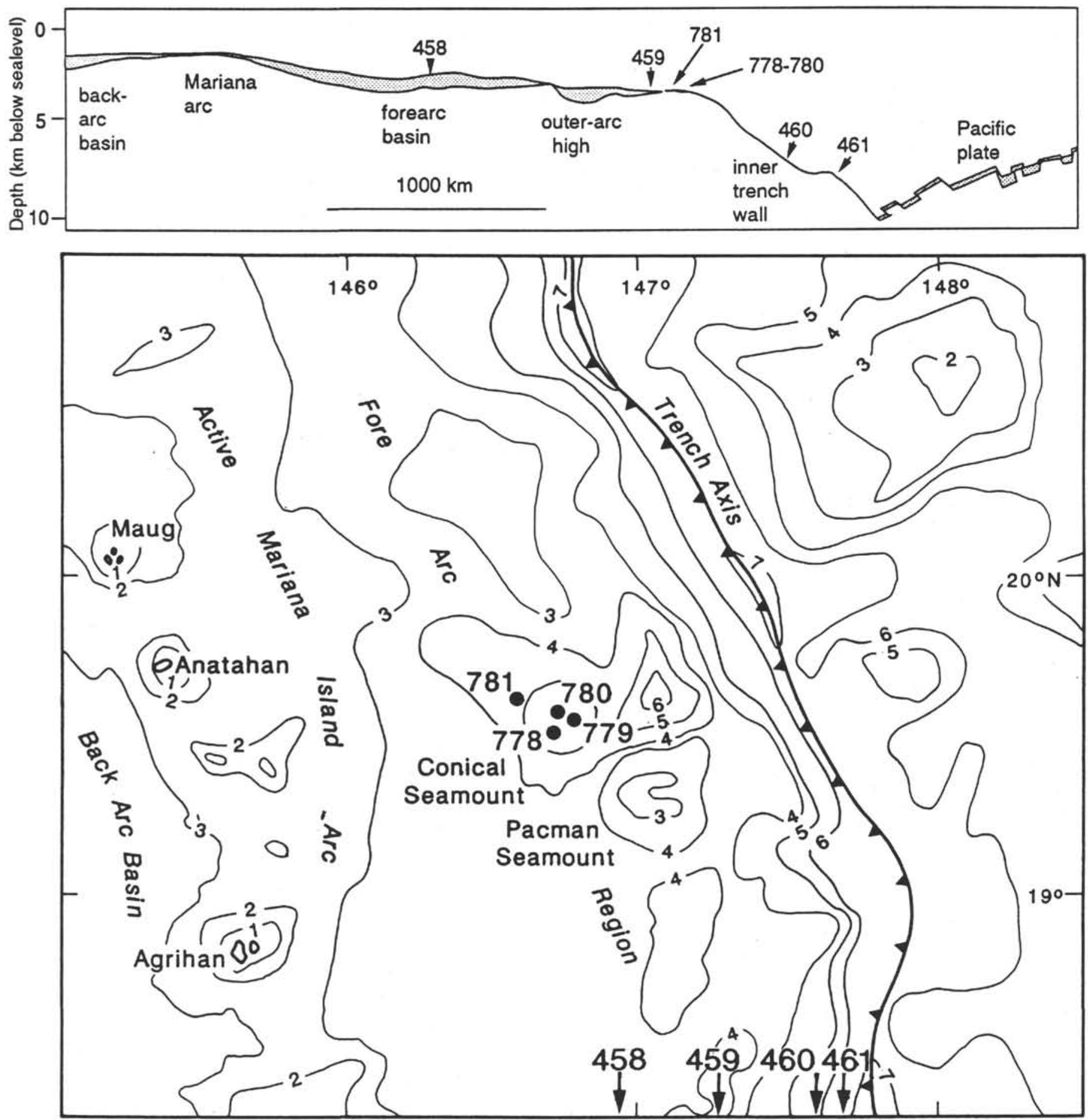

Figure 3. Oligocene-Eocene drill sites from ODP Leg 125 (solid circles) and DSDP Leg 60 (open circles) in the Mariana forearc as seen in plan view and schematic cross section.

lithosphere, the products of forearc magmatism, or a mixture of these. The reconstruction in Figure 4 assumes that much of the outer forearc is composed of a melange of these rock types.

4. The Mariana Ridge includes the islands of Guam and Saipan. Tracey et al. (1964) mapped Guam. Reagan and Meijer (1984) subsequently revised its stratigraphy, and Meijer et al. (1983) provided K-Ar radiometric ages. These studies establish the oldest unit on Guam as the Eocene Facpi Formation (43.8 $\pm 1.6 \mathrm{Ma}$ ), which consists of interbedded boninite pillow lavas and breccia, locally with tholeiitic rocks as the youngest member. The Facpi Formation is paraconformably overlain by the calc-alkaline, tholeiitic, and boninitic pyroclastic rocks and lavas of the Alutom Formation (35tl Ma). The final event was the intrusion of sills at about $32 \mathrm{Ma}$, possibly related to the initial rifting of the Palau-Kyushu Ridge (Meijer et al., 1983). Cloud et al. (1956) and Schmidt (1957) mapped Saipan, K-Ar radiometric dating again supplied by Meijer et al. (1983). The lowest unit on this island is late Eocene 


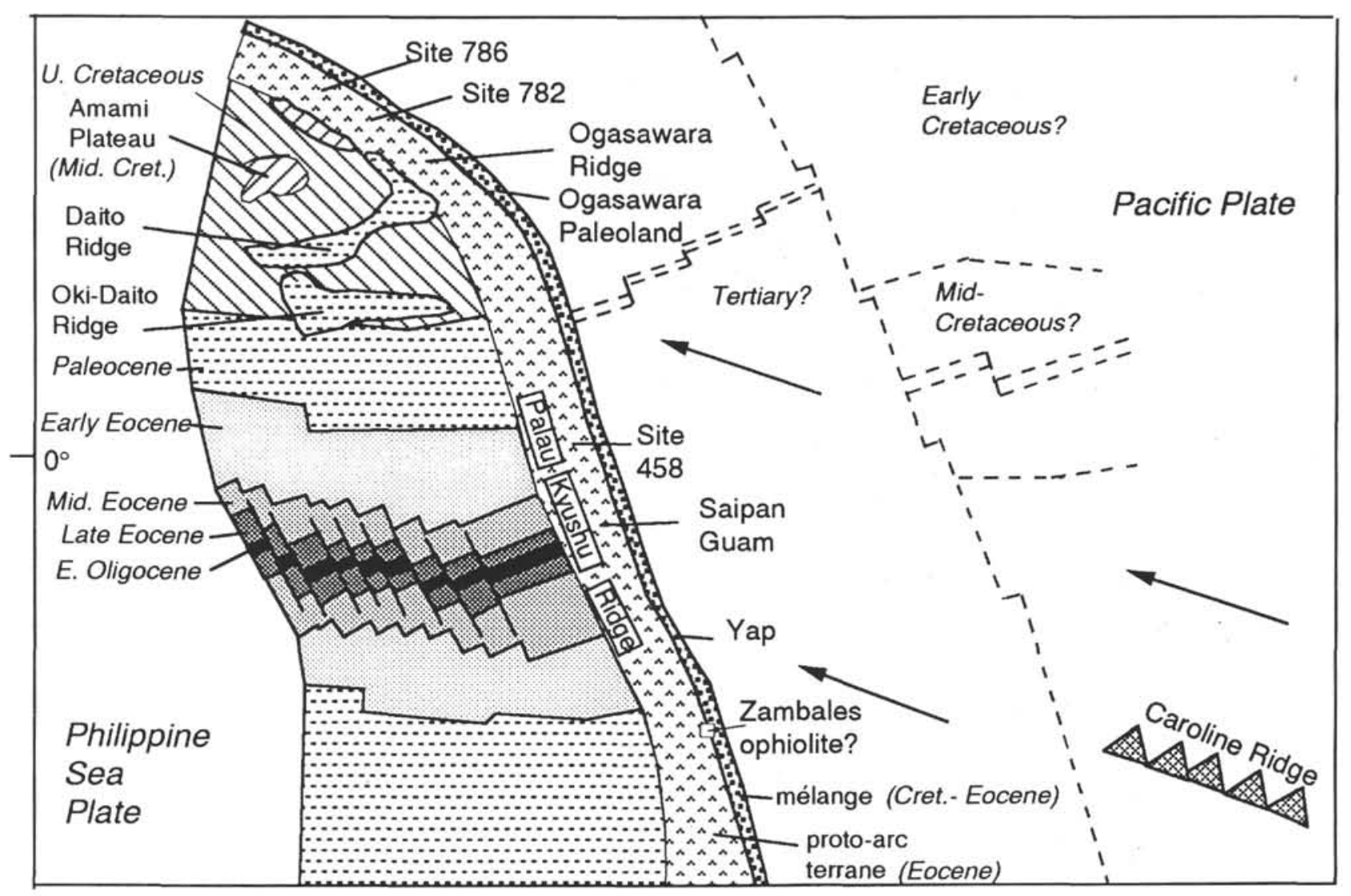

Figure 4. Representation of the Western Pacific at the end of the Eocene, based on references cited in the text, showing Leg 125 sites in their possible geologic context.

boninitic series dacite of the Sankakuyama Formation (41 Ma), followed by the andesitic pyroclastic rocks and lava flows of the late Eocene-Oligocene ( $35.7 \pm 0.5 \mathrm{Ma}$ ) Hagman Formation.

5. The Mariana outer-arc high was drilled during DSDP Leg 60. Site 458 contains five units of pillow lavas and sheet flows (or sills) of bronzite andesite and tholeiitic basaltic andesite composition and probable early Oligocene age. Site 459 contains pillowed and sheet flows of tholeiitic basalt and andesite of probable Eocene age (e.g., Natland and Tarney, 1981). One bronzite andesite sample from Site 458 gives an age of 33.6 $\mathrm{Ma}$, whereas three basaltic andesites give ages of 34,19 , and $20 \mathrm{Ma}$ (Meijer et al., 1983). Hussong and Uyeda (1981) argue that the younger ages are reset, but the experience of Leg 125 scientists is that they could equally be young sills. A basalt from Site 459 gave a late Eocene age of $36 \mathrm{Ma}$ (Meijer et al., 1983).

6. The Mariana-Palau outer forearc. Scientists drilled the "basement" of the outer Mariana forearc on Conical Seamount during Leg 125 , characterizing the structure as a serpentinite seamount made up of serpentinite mud enclosing serpentinized harzburgite (and other) clasts (Fryer, Pearce, Stokking, et al., 1990). This result confirms earlier dredge and submersible studies (e.g., Fryer et al., 1985). The inner Mariana trench wall was drilled during Leg 60, at depths of $6500-7000 \mathrm{~m}$. Sites 460 and 461 provided a polymict assemblage of basalt, metabasalt, bronzite-andesite, and gabbro fragments. Extensive dredging along the Mariana, Yap, and Palau inner trench walls (locations in Fig. 1) also produced a range of rock types, including boninite, tholeiitic basalt, and andesite, alkali basalt, gabbro, metabasalt, serpentinite, and volcaniclastic sediment (Bogdanov et al., 1977; Dietrich et al., 1977; Beccaluva et al., 1980; Bloomer, 1983; Bloomer and Hawkins, 1983, 1987; Johnson and Fryer, 1990). At one locality more than $50 \mathrm{~km}$ from the trench, Johnson et al. (1991) dated some of the sediments and metabasalt clasts as Cretaceous. They suggest that the outer Mariana forearc contains accreted fragments of Cretaceous oceanic lithosphere, probably extensively faulted and intruded by the products of arc volcanism. Following Ogawa and Naka (1984), we treat the outer forearc as a transform fault terrane intruded by the early products of supra-subduction zone volcanism, similar to that seen on land in the Setogawa and Mineoka forearc belts in Japan and on the island of Yap (see Fig. 1). Note that the construction in Figure 4 does not depict serpentinite intrusion or seamount accretion, both of which took place mainly after the end of the Eocene.

7. The Palau Kyushu Ridge. Mason et al. (1956) mapped the Palau islands at the southern end of the ridge and divided the volcanic section into three formations, the Babelthaup, the Ameleiik, and the Ngeremlengui. The Babelthaup Formation, which contains boninite series rocks, has not yet been dated, and the Aimeliik Formation gave an early Oligocene radiometric date but an Eocene nannofossil age (Meijer et al., 1983). Further north, drilling at DSDP Site 448 penetrated an island arc basement of tholeiitic pillow lavas and volcaniclastic breccia dated at 34-32 Ma (Scott and Kroenke, 1983). Drilling at DSDP Sites 290 and 296 encountered andesitic breccia (Meijer, 1975). A Japanese dredging program recovered andesite, diorite, and tonalite from the northern part of the Palau-Kyushu Ridge (Shiki et al., 1985), with $\mathrm{K}-\mathrm{Ar}$ ages of $51,37.4 \pm 6.4$, and $37.5 \pm 1.9 \mathrm{Ma}$. The last two dates suggest that the Palau-Kyushu Ridge could have been the site of island arc tholeiite eruptions at the same time as boninitic volcanoes were erupting in the Izu-Bonin and Mariana forearcs further east.

8. The West Philippine Basin. Hilde and Lee (1984) summarized the results of paleomagnetic studies in the West Philippine basin, and their magnetic lineations are shown in Figure 4. They demonstrate that the basin formed by two distinct stages of spreading, one before and one after about $45 \mathrm{Ma}$. From at least $60 \mathrm{Ma}$ (magnetic anomaly 26) to $45 \mathrm{Ma}$ 
Table 1. Summary of basement drilling during ODP Leg 125.

\begin{tabular}{|c|c|c|c|c|c|c|c|c|}
\hline Hole & $\begin{array}{c}\text { Latitude } \\
\left({ }^{\circ} \mathrm{N}\right)\end{array}$ & $\begin{array}{l}\text { Longitude } \\
\left({ }^{\circ} \mathrm{E}\right)\end{array}$ & $\begin{array}{c}\text { Water } \\
\text { depth }(m)\end{array}$ & $\begin{array}{l}\text { No. of } \\
\text { cores }\end{array}$ & $\begin{array}{l}\text { Length } \\
\text { cored (m) }\end{array}$ & $\begin{array}{c}\text { Basement } \\
\text { depths }(m)\end{array}$ & $\begin{array}{c}\text { Basement } \\
\text { sampled }(\mathrm{m})\end{array}$ & $\begin{array}{l}\text { Basement } \\
\text { lithologies }\end{array}$ \\
\hline $778 \mathrm{~A}$ & $19^{\circ} 29.93^{\prime}$ & $146^{\circ} 39.93^{\prime}$ & 3913.7 & 13 & 107.6 & $29.8-107.6$ & 14.65 & Harzburgite, dunite, metabasalt \\
\hline $779 \mathrm{~A}$ & $19^{\circ} 30.75^{\prime}$ & $146^{\circ} 41.75^{\prime}$ & 3947.2 & 37 & 319.2 & $10.6-317.2$ & 65.38 & Harzburgite, dunite, gabbro, metabasalt \\
\hline $780 \mathrm{C}$ & $19^{\circ} 32.53^{\prime}$ & $146^{\circ} 39.21^{\prime}$ & 3083.4 & 18 & 163.5 & $14.0-163.5$ & 8.39 & Harzburgite, dunite, metabasalt \\
\hline $780 \mathrm{D}$ & $19^{\circ} 32.55^{\prime}$ & $146^{\circ} 39.20^{\prime}$ & 3088.9 & 7 & 32.4 & $15.4-32.4$ & 4.77 & Harzburgite, dunite, metabasalt \\
\hline $782 \mathrm{~A}$ & $30^{\circ} 51.66^{\prime}$ & $141^{\circ} 18.85^{\prime}$ & 2958.6 & 50 & 476.8 & $409.2-476.8$ & 0.93 & Tholeiitic, andesite-rhyolite \\
\hline $782 \mathrm{~B}$ & $30^{\circ} 51.60^{\prime}$ & $141^{\circ} 18.84^{\prime}$ & 2965.9 & 1 & 9.6 & $459.3-468.9$ & 0.10 & Tholeiitic, andesite-rhyolite \\
\hline $783 \mathrm{~A}$ & $30^{\circ} 57.86^{\prime}$ & $141^{\circ} 47.27^{\prime}$ & 4648.8 & 18 & 168.2 & $120.0-168.2$ & 11.71 & Harzburgite, dunite, metabasalt \\
\hline $784 \mathrm{~A}$ & $30^{\circ} 54.49^{\prime}$ & $141^{\circ} 44.27^{\prime}$ & 4900.8 & 45 & 425.3 & $321.1-425.3$ & 26.27 & Harzburgite, dunite, metabasalt \\
\hline $786 \mathrm{~A}$ & $31^{\circ} 52.48^{\prime}$ & $141^{\circ} 13.58^{\prime}$ & 3058.1 & 19 & 166.5 & $124.9-166.5$ & 3.60 & Boninite series volcanics + various dikes \\
\hline $786 \mathrm{~B}$ & $31^{\circ} 52.45^{\prime}$ & $141^{\circ} 13.59^{\prime}$ & 3071.0 & 72 & 666.0 & $162.5-826.6$ & 190.07 & Boninite series volcanics + various dikes \\
\hline
\end{tabular}

(anomaly 20), spreading took place about a NW-SE (present orientation) spreading axis at a half-rate of $44 \mathrm{~mm} \mathrm{a}^{-1}$; after $45 \mathrm{Ma}$. Spreading changed to E-W (present orientation) and slowed to a half-rate of $18 \mathrm{~mm}$ $\mathrm{a}^{-1}$, ending at $35 \mathrm{Ma}$ (anomaly 13). The age of the start of spreading in the basin is uncertain because of loss of lithosphere by subduction to the northwest. Radiometric dates from DSDP cores and dredges within the basin are generally consistent with the magnetochronology to within about 2 Ma (e.g., McKee, 1975).

The basement lithologies in the West Philippine Basin were recovered for study during DSDP Legs 31 and 59 (e.g., Meijer, 1975; Scott and Kroenke, 1983) and during an extensive Japanese dredging program (Shiki et al., 1985). The Amami Plateau in the north contains Cretaceous (85-75 Ma) volcanic and plutonic rocks of probable arc affinities (primarily basalt, two-pyroxene andesite and a hornblende tonalite) (Tokuyama, 1985). FeTi basalt dated at $56 \mathrm{Ma}$ has been recovered from the Oki-Daito Ridge, and a further suite of rocks dating from 50 to $48 \mathrm{Ma}$ has been recovered from several localities in the northern and southern margins of the basin. The latter include trachyandesite from the Amami Plateau and Daito Ridge and an alkali basalt on the Benham Rise in the south (DSDP Site 292) just east of Luzon (Aoki and Ishikawa, 1985; Meijer, 1975).

11. The Zambales ophiolite of Luzon. The Zambales ophiolite in Luzon (Philippines) is the best preserved accessible fragment of Eocene oceanic lithosphere in the Western Pacific and therefore holds important clues to the Eocene evolution of the region (e.g., Hawkins and Evans, 1983; Rossman et al., 1989; Geary et al., 1989). The ophiolite forms two distinct blocks. The Acoje Block in the north has island arc tholeiite to boninitic affinities and is thought to have been overlain formerly by more evolved rocks than those currently preserved. The Coto Block in the south has been described as having tholeiitic back-arc-basin basalt affinities. The Acoje Block has a thicker reconstructed crustal section $(7-10 \mathrm{~km})$ than the Coto Block, which has a typical oceanic crustal thickness (5-6 km). Hawkins and Evans (1983) infer that the ophiolite originated in a back-arc setting, in which both blocks formed above a subduction zone. In contrast, Geary et al. (1989) conclude that the Acoje-Coto pair formed in a "proto-forearc" setting, in which the Coto Block represents the result of spreading prior to the initiation of subduction and the Acoje Block represents the product of early subduction magmatism. Despite these conflicting interpretations, the Acoje Block may be the best analog we have for the crust of the Izu-Bonin outer-arc high, whereas the Coto Block is a possible candidate for crust created just before or at the start of subduction.

Paleomagnetic studies have established that each of the above terranes was both translated and rotated since the middle Eocene while the West Philippine Sea Plate was subducted in a NNW direction beneath Japan. Over this period, collisions with oceanic plateaus, seamount chains, and microcontinents caused further local rotations. Louden (1977) and others demonstrate a post-Eocene northward translation of about $20^{\circ}$ (such that the early arc lay close to the paleo-Equator) and a clockwise rotation of $60 \pm 10^{\circ}$ for the Bonin
Islands, Guam, and the West Philippine Basin. By contrast, the Zambales ophiolite rotated counterclockwise by about $90^{\circ}$ (Fuller et al., 1989). The map in Figure 4 takes these motions into account. The original position of the Zambales ophiolite is highly speculative, although our unpublished data do show similarities in composition between boninite from the Zambales ophiolite and boninite from the southernmost part of the "proto-arc" on Palau. The age structure of the Pacific Plate is based on the reconstruction of Engebretson et al. (1985), and the requirement for subduction of Tertiary lithosphere at the start of subduction is based on the thermal constraints for boninite genesis discussed in this chapter.

\section{MODELS FOR THE INITIATION OF SUBDUCTION}

Tectonic reconstructions of the Western Pacific in the early Oligocene are broadly similar (Fig. 5D). They show a single zone of WNW subduction, behind which the Bonin, Mariana, and Yap forearcs together with the Palau-Kyushu Ridge combine to form a single arc-trench system. At this time, spreading in the West Philippine Basin has just ceased and the Parece Vela Basin has not started to open. Opinions diverge, however, over the Eocene reconstruction. Two basic types of paleotectonic map have been produced for the Eocene. The first (Uyeda and Ben Avraham, 1972; Hilde et al., 1977; Hussong and Uyeda, 1981) requires normal seafloor spreading within the Philippine Sea prior to initiation of subduction at a transform fault (Figs. 5A and B). In this model, the change from transform motion to subduction coincides with the change in absolute motion of the Pacific plate at about $43 \mathrm{Ma}$ (Clague and Dalrymple, 1987). The second type of map requires that subduction beneath the West Philippine Basin started prior to this change in plate motion (Lewis et al., 1982; Ogawa and Naka, 1984; Seno and Maruyama, 1984; Honza, 1991). To achieve a consistent geometry, Seno and Maruyama (1984) invoke the subduction of an additional plate, the New Guinea plate, beneath the West Philippine Basin. This plate acts as a "buffer" between the Pacific plate and Philippine plate so that there is no need to invoke a relationship between Pacific plate motion and the start of subduction. They also argue that the presence of this plate better explains the dike orientations in Chichi-jima as well as a number of aspects of the early Tertiary evolution of other parts of the Western Pacific. There are a series of variants on this second map, a simple version of which is shown as Figure $5 \mathrm{C}$.

The direct evidence for subduction prior to $43 \mathrm{Ma}$ in the Western Pacific hinges on the 50-43 Ma ages in lavas of island-arc composition from the northern Palau-Kyushu Ridge (Ozima et al., 1977) and on the $48 \mathrm{Ma} \mathrm{Ar}$-Ar age determination, and the middle Eocene radiolarian ages for part of Chichi-jima (Dobson, 1986). Given the absence of subduction-related rocks of this age in the southern part of the Eocene province, Seno and Maruyama (1984) suggested that subduction started at about $48 \mathrm{Ma}$ in the north but at $43 \mathrm{Ma}$ in the south. One problem with this model is that there is no evidence that the Philippine Sea occupied a backarc setting. Hilde and Lee (1984) point out that the longevity of the West Philippine Basin and the 


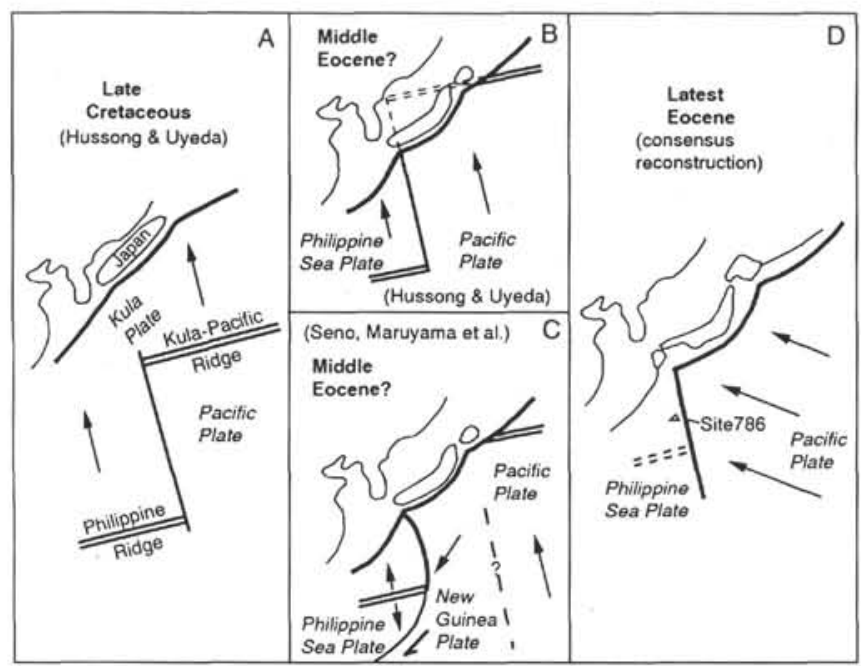

Figure 5. Current models for the tectonic evolution of the Western Pacific during the Eocene. A, B, and D show the model of Hussong and Uyeda (1981), in which Eocene boninitic terranes are explained solely in terms of a change from a transform to a subduction margin. $\mathbf{C}$ shows the type of model envisaged by Seno and others, in which subduction predates plate reorganization and the boninitic terranes are related to ridge subduction upon disappearance of the New Guinea plate.

distance between the spreading axis and the postulated subduction zone are much greater than in any extant backarc basin. A second problem is that the evidence itself is not "watertight." Of the six published radiometric ages on the lavas from Chichi-jima (including our own $\mathrm{Ar}-\mathrm{Ar}$ measurement reported earlier), only one is greater than $43 \mathrm{Ma}$, and there is still a question over whether the glass analyzed had trapped excess Ar. Moreover, the $50 \mathrm{Ma}$ lavas from the Palau-Kyushu Ridge need not be related to subduction. They could have originated in an intraplate setting and acquired an inherited subduction component from the Cretaceous arc lithosphere known to underlie part of the region. The fact that other early Tertiary lavas from the West Philippine Basin have an intraplate composition lends some support to such a hypothesis. The majority of the authors of this chapter therefore prefer the Uyeda and Ben Avraham model, on the basis that the concept of subduction before plate reorganization requires further proof, but with the caveats that neither model is yet able fully to explain all the observations and that we still lack evidence for the nature and age of the oceanic lithosphere subducted during the Eocene.

The common theme in both models (Figs. 5B and 5C) is the initiation of subduction at a transform fault. Karig (1982) and Casey and Dewey (1984) both examine this theme, citing the Eocene of the Western Pacific as a type example. One of their key lines of evidence comes from the West Philippine Basin. This marginal basin contains magnetic lineations that are suborthogonal to, and in part contemporaneous with, the trend of the incipient volcanic arc as defined by the location of the Palau-Kyushu Ridge (Uyeda and Ben-Avraham, 1972; Louden, 1976; Watts et al., 1976; Lee and Hilde, 1982).

Casey and Dewey (1984) point out that there are many areas where adjustments of poles of relative plate rotation are known to have resulted in transpression or transtension along transform faults. For example, the change from transform motion to transpression has been documented in the Central Atlantic where readjustment was achieved by a period of asymmetric spreading and ridge jumping (Fox et al., 1969). Casey and Dewey argue that if the change in relative motion is sufficiently large and abrupt, then the convergence may become permanent. The Casey and Dewey model is reproduced here in Figure 6. In their model, the change in relative plate motion is marked by a change in spreading direction. Eventually the spreading axis in the trapped basin dies, and ridge subduction is an important part of the transition to current subduction geometries. Casey and Dewey note the potential importance of boninitic magmatism in this setting. Further investigation of their model is an important objective of this chapter.

Geological evidence for the initiation of subduction at a transform fault in the Western Pacific is presented by Ogawa and Naka (1984). In particular, they note the variety of metamorphic grades (including amphibolite facies) and the abundant evidence for brittle-to-ductile cataclastic deformation in rocks from the inner trench wall. They argue that at least some of these events took place in a transform zone that subsequently became the site of subduction.

\section{THE NATURE OF THE EARLY ARC LITHOSPHERE: EVIDENCE FROM LEG 125}

\section{Lithostratigraphy of the Outer Arc High}

As noted earlier, deep penetration into the basement of the IzuBonin outer-arc high was achieved at Site 786. Hole 786A cored $125 \mathrm{~m}$ of sediment and $42 \mathrm{~m}$ of basement. Hole $786 \mathrm{~B}$ cored a further $664 \mathrm{~m}$ of basement. Shipboard core descriptions (Fryer, Pearce, Stokking, et al., 1990) augmented by the lithostratigraphic studies of Arculus et al. (this volume), the K-Ar dating of Mitchell et al. (this volume), and the structural and volcanological observations of Lagabrielle et al. (this volume) provide a picture of a complex Eocene volcanic edifice of boninitic composition. Figure 7 shows a schematic section for Site 786 (a composite of Holes 786A and 786B). The complete section is given in Arculus et al. (this volume).

The edifice is similar in structure to oceanic volcanoes from other settings, having a core of dikes and pillow lavas at its base, a middle part of massive lavas and breccia, and an upper part containing the products of explosive volcanism as well as massive lavas and breccia. The edifice was intruded by a series of dikes or sills, cut by normal faults, and covered by middle Eocene to early Pleistocene sediments. Lagabrielle et al. (this volume) conclude on the basis of the distribution of pyroclastic flows and surficial oxidation of the clasts that the edifice had emerged at least locally above sea level. Heling and Schwarz (this volume) reach a similar conclusion from the clay mineral fraction in the intercalated sediments. Several lines of evidence indicate that this constructional stage was succeeded by a period of active subsidence at the end of the Eocene. Lagabrielle et al. (this volume) suggest that the upper main breccia interval in Hole 786B may be deposited during an episode of subsidence. Milner (this volume) points out that Eocene foraminifers in the sediments directly overlying the edifice lived at depths greater than $1000 \mathrm{~m}$. Subsidence curves for the sedimentary sequence show an increased rate of sedimentation in the Oligocene (Fryer, Pearce, Stokking et al., 1990). Dating by Mitchell et al. (this volume) indicates that the constructional stage took place in the late Eocene at about $41 \mathrm{Ma}$ and that intrusion of the late dikes mostly took place in the earliest Oligocene at about $35 \mathrm{Ma}$. If this chronology is correct, subsidence must have predated dike intrusion.

We cored only a small quantity of andesite and dacite of the island-arc tholeiite series at the other forearc site, Site 782. These do not give a consistent age, although the two oldest ages of about 31 and 36 Ma point to late Eocene or early Oligocene eruption ages.

\section{Petrologic Characteristics of the Boninite Series Volcanics}

Arculus et al. (this volume) present and interpret the major element geochemistry of the Leg 125 samples. They subdivide the igneous rocks into eight lithostratigraphic groups on the basis of $\mathrm{CaO}-\mathrm{MgO}$ $\mathrm{SiO}_{2}$ variations. We reproduce their two principal projections in Figure 8. Both diagrams highlight the remarkable range of compositions of the Leg 125 igneous rocks. They encompass, within a single edifice, the fields of almost all the boninite series volcanic rocks plotted by Crawford et al. (1989) in their recent synthesis. In the $\mathrm{MgO}-\mathrm{SiO}_{2}$ diagram (Fig. 8A), the boninite and the more silica-rich bronzite andesite display the "classic" characteristics of boninite series rocks, namely high magnesium content 

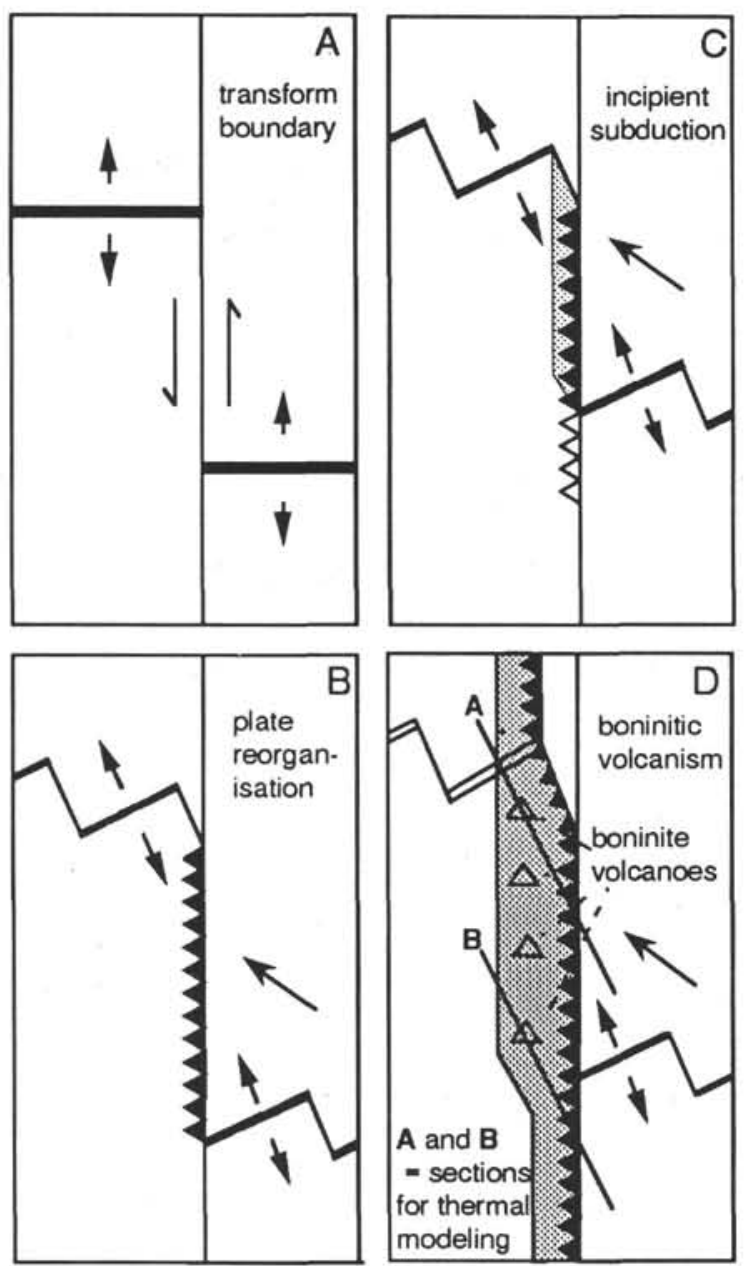

Figure 6. Casey and Dewey (1984) model for the initiation of subduction along a transform-fracture zone system. On their diagram, thick black lines are spreading ridges, thin double lines represent extinct ridge segments, medium straight lines represent transform fault/fracture-zone systems, solid triangles represent a subduction zone, open triangles represent a former subduction zone, and shaded areas represent areas of subduction. The model is aimed at representing the Western Pacific plate reorganization, in which the fracture zone was striking NNW. Lines $\mathrm{A}$ and $\mathrm{B}$ are used for thermal modeling in Figure 26.

at high silica concentrations. The andesite, dacite, and rhyolite are more similar to evolved rocks of the calc-alkaline series but are clearly cogenetic with the boninite on isotopic, trace element, and petrographic criteria (Pearce et al., this volume; Murton et al., this volume; van der Laan et al., this volume).

Arculus et al. (this volume) use the $\mathrm{CaO}-\mathrm{SiO}_{2}$ diagram (Fig. 8B) to subdivide the lavas and dikes from Leg 125 into low-Ca, intermediate- $\mathrm{Ca}$, and high-Ca series. The rationale for this threefold subdivision at Site 786 is stratigraphic as well as chemical, as we explain below. Crawford et al. (1989) recommend a twofold subdivision of boninite into high- $\mathrm{Ca}$ and low-Ca groups on the basis of $\mathrm{CaO} / \mathrm{Al}_{2} \mathrm{O}_{3}$ ratios. Their dividing line is at a ratio of 0.75 . Thus, our high-Ca boninite (average $\mathrm{CaO} / \mathrm{Al}_{2} \mathrm{O}_{3}$ ratio of 0.84 ) corresponds to their high-Ca boninite group. Both our intermediate-Ca boninite (average $\mathrm{CaO} / \mathrm{Al}_{2} \mathrm{O}_{3}$ ratio of 0.60 ) and low-Ca boninite (average $\mathrm{CaO} / \mathrm{Al}_{2} \mathrm{O}_{3}$ ratio of 0.41 ) correspond to their low-Ca boninite group. We summarize the main stratigraphic, geochemical, and petrographic features of these rock types in Table 2 .

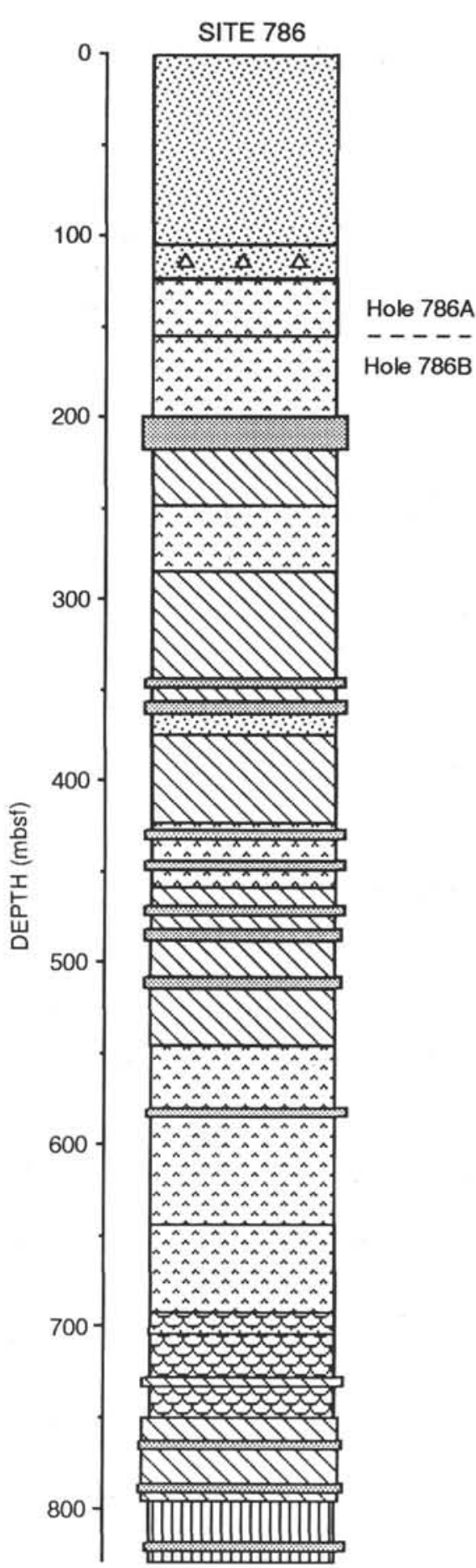

Andesite, dacite and rhyolite flows with intercalated sandstone and breccia

ICBrzA flows

Andesite, dacite and rhyolite flows

ICBrzA flows and breccia

ICB breccia

LCB pillows and hyaloclastite

Rhyolite dyke swarm

LCBrzA dyke swarm

Figure 7. Schematic lithostratigraphic section for Site 786 in the Izu-Ogasawara forearc. The shaded bands cutting the section represent late dikes, mostly of ICB and $\mathrm{HCB}$ composition. For the detailed section, see Arculus et al. (this volume).

In terms of distribution within the core (Fig. 7), the low-Ca boninite and low-Ca bronzite andesite are found only at the base of the edifice. The low-Ca bronzite andesite is restricted to a dike swarm at the deepest level drilled and the low-Ca boninite to an overlying sequence of pillow lava, pillow breccia, and hyaloclastite. The intermediate-Ca boninite mainly occurs directly above the pillow lava 

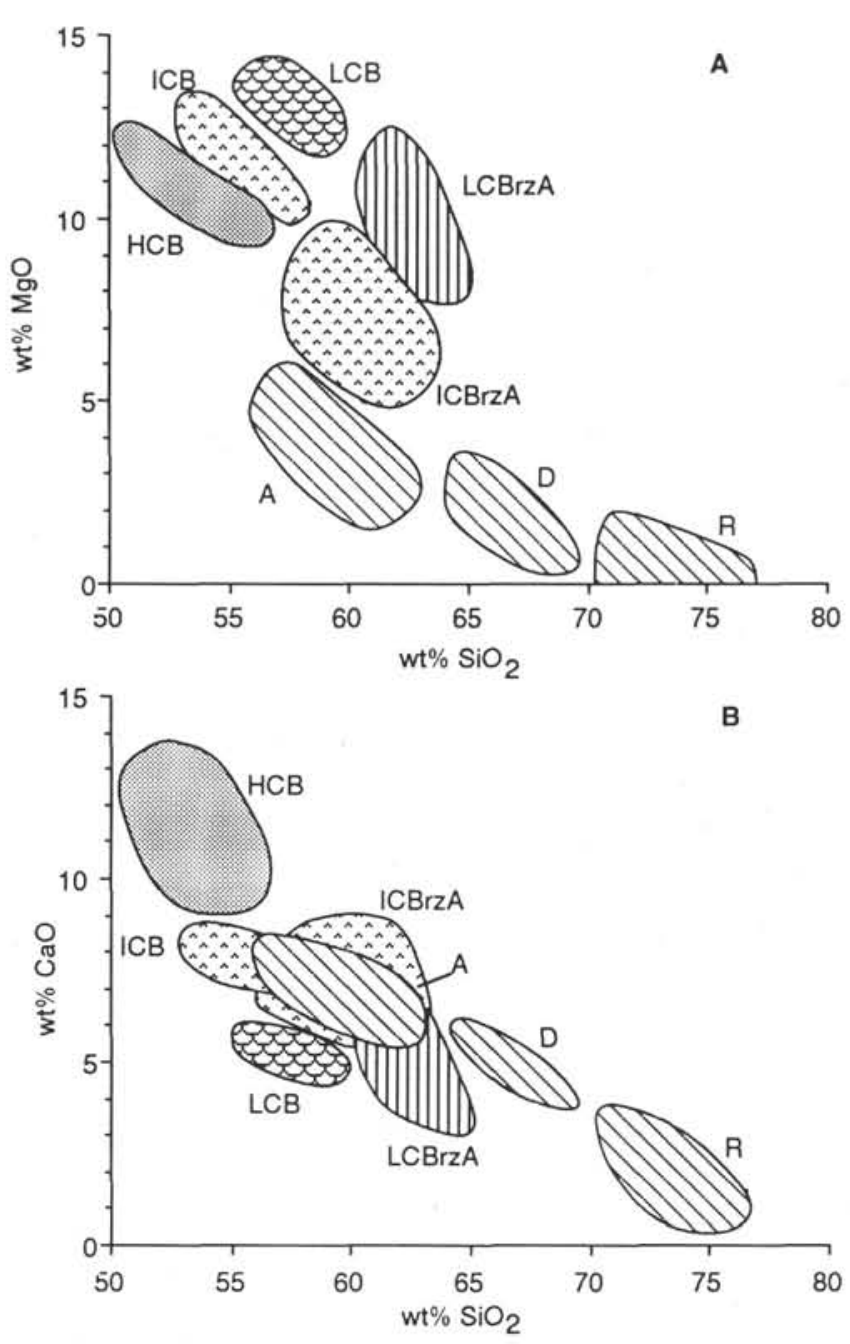

Figure 8. $\mathrm{MgO}-\mathrm{SiO}_{2}$ and $\mathrm{CaO}-\mathrm{SiO}$ diagrams used to define the rock types from the Eocene boninitic edifice at Site 786 (from Arculus et al., this volume). LCB = low-Ca boninite, $\mathrm{LCBrzA}=$ low-Ca bronzite andesite, $\mathrm{ICB}=$ intermediate$\mathrm{Ca}$ boninite, $\mathrm{ICBrzA}=$ intermediate-Ca bronzite andesite, $\mathrm{A}=$ andesite, $\mathrm{D}=$ dacite, $\mathrm{R}=$ rhyolite, $\mathrm{HCB}=$ high-Ca boninite.

sequence, although it also forms rare clasts in breccia at higher levels (notably at the base of Hole 786A) and a small number of late dikes. The intermediate-Ca bronzite andesite, andesite, dacite, and rhyolite make up the main series of dikes, massive and pyroclastic flows, and breccia in the middle to upper part of the edifice. Rhyolite forms a series of dikes in the lower part of the sequence. High-Ca boninite is restricted to a set of late dikes or sills that is distributed throughout the basement.

Table 2 also summarizes the mineralogy of the magma groups, using data from van der Laan et al. (this volume). The boninite is of most interest, being closest to primary magma compositions. The low-Ca, intermediate-Ca, and high-Ca boninite contain phenocrysts of olivine and orthopyroxene, typically with $\mathrm{Mg \# s}$ for olivine of between 86 and 87 and for orthopyroxene of between 80 and 87 . $\mathrm{Cr}$-spinels have Cr\#s from 65 to 84 . Only intermediate-Ca and high-Ca boninite contains clinopyroxene phenocrysts (with $\mathrm{Mg \# s}$ of between about 80 and 87 ) and groundmass plagioclase (An mainly between $80 \%$ and $85 \%$ ). Bronzite andesite contains phenocrysts of strongly-zoned plagioclase in addition to rare, resorbed olivine and clinopyroxene and orthopyroxene. The most evolved rock type is rhyolite, containing hypersthene, plagioclase $\left(\mathrm{An}_{50}\right)$ and magnetite as phenocryst phases. A summary diagram of the crystallization sequence for the intermediate-Ca boninite series is given by van der Laan et al. (this volume) and is reproduced as Figure 9.

Arculus et al. (this volume) use the major-element data to demonstrate that all three boninite groups experienced similar degrees of olivine and pyroxene fractionation but cannot be related to each other by fractionation of these phases. Distinct primary magma compositions must therefore be involved. They also find that the low-Ca and intermediate- $\mathrm{Ca}$ boninite may be related to the equivalent bronzite andesite by olivine, pyroxene, and plagioclase fractionation but that this does not occur along simple liquid lines of descent. Many of these rocks are highly porphyritic and can be viewed as mushes rather than liquids. This point is emphasized by van der Laan et al. (this volume), who stress that mafic phases in the bronzite andesite can be as magnesian as those in the boninite. We therefore view the variations in the high- $\mathrm{Mg}$ rocks in Figure 8 in terms of a combination of fractional crystallization and crystal cumulation. The andesite, dacite, and rhyolite can be related by plagioclase, pyroxene, and magnetite crystallization but can also contain highly magnesian crystals. van der Laan et al. (this volume) view these as filter-pressed extracts from a crystal-charged magma chamber of bronzite andesite composition.

\section{Trace Element Characteristics}

Murton et al. (this volume) describe the principal trace element characteristics of the Leg 125 samples. Table 2 contains the average values for some elements in the different rock types, and Table 3 provides a representative set of analyses of the various rock types. The andesite, dacite, and rhyolite of the boninite series plot on simple fractionation vectors from intermediate-Ca boninite and intermediate-Ca bronzite andesite. The data in Table 3 demonstrate the steady increase in the incompatible elements, Th and $\mathrm{Zr}$, through this fractionation series. The compatible elements, $\mathrm{Ni}, \mathrm{Sr}$, and $\mathrm{Ti}$, help to monitor the behavior of mafic minerals, plagioclase, and oxides, respectively. The fact that $\mathrm{Ni}$ continues to have high values in the bronzite andesite is an indicator of the importance of crystal cumulation in this rock type. $\mathrm{Sr}$ only begins to fall in concentration in the andesites, a reflection of the late crystallization of plagioclase in the boninitic series, compared with the calc-alkaline series (Fig. 9). Ti only starts to fall at silicic compositions in response to magnetite crystallization, in marked contrast to the calc-alkaline series, where magnetite is an early-crystallizing phase.

Figure 10 gives trace element patterns for the main boninite types. One problem in constructing these patterns is the mobility of many elements during alteration. These include, in addition to the alkali and alkali earth elements, the $\mathrm{Pb}, \mathrm{U}, \mathrm{REEs}, \mathrm{Y}$, and $\mathrm{P}$. Taylor et al. (in press) also recognize the mobility of the REEs in lavas from Leg 126. Primary REE patterns are flat to slightly MREE-depleted with respect to heavy REEs $\left((\mathrm{Tb} / \mathrm{Yb})_{\mathrm{n}}=1-0.8\right)$ and light REEs $\left((\mathrm{La} / \mathrm{Sm})_{\mathrm{n}}=1-1.5\right)$ (Fig. 10A). The low-Ca and intermediate-Ca boninite from Site 786B (together with the bronzite andesite, andesite, dacite, and rhyolite, not shown in this figure) have the highest $\mathrm{La} / \mathrm{Sm}$ ratios and lowest $\mathrm{Tb} / \mathrm{Yb}$ ratios, producing slightly $\mathrm{U}$-shaped profiles. By contrast, the intermediate-Ca boninite from Site $786 \mathrm{~A}$ and the intermediate-Ca and high$\mathrm{Ca}$ boninite late dikes have much flatter patterns. Murton et al. (this volume) note that the low-Ca boninite has a higher total REE content than the more silicic intermediate-Ca boninite, evidence of dilution of the REE content of the latter by crystal cumulation.

Full trace element patterns, here normalized to a N-MORB composition (Fig. 10B), highlight four additional features, namely (1) selective enrichment of the large-ion lithophile (LIL) elements relative to the high field strength (HFS) elements, (2) a positive anomaly in $\mathrm{Hf}$ and $\mathrm{Zr}$ relative to $\mathrm{Sm},(3)$ a negative anomaly of Ti relative to $\mathrm{Y}$ and the middle to heavy 
Intermediate-Ca boninite series

$$
\text { boninite } \mathrm{BrzA} \text { andesite dacite rhyolite }
$$

olivine:

plagioclase:

orthopyroxene:

clinopyroxene:

quartz:

Figure 9. Crystallization history of the intermediate-Ca boninite series (from van der Laan et al., this volume).
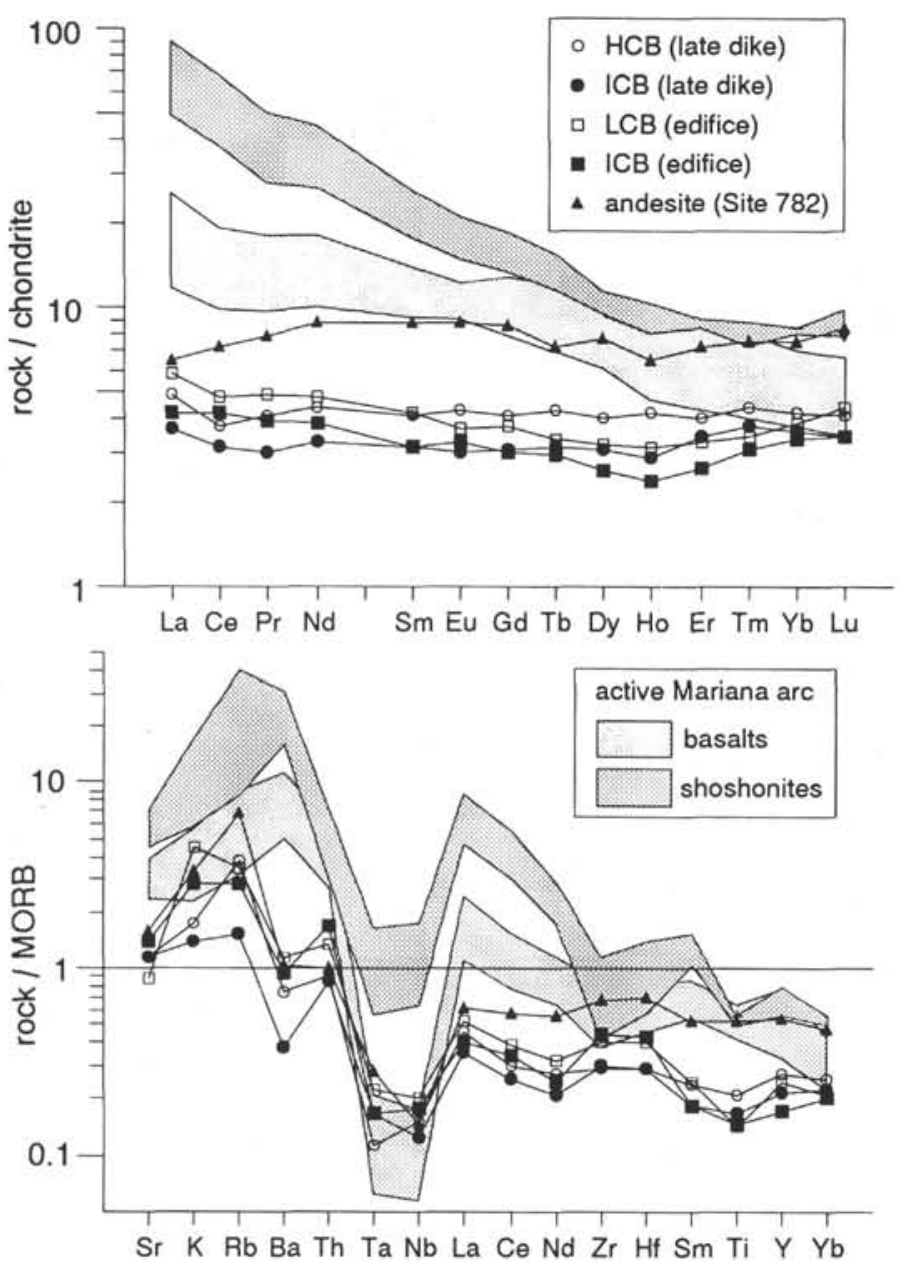

Figure 10. REE patterns (A) and MORB-normalized trace element patterns (B) from type examples of the low-Ca, intermediate-Ca, high-Ca boninite and tholeiite from Site 786. Fields of calc-alkaline basalts and shoshonites from the Mariana and Southern Volcano (Bonin) arcs (data of Lin et al., 1989) are given for comparison.

REEs (Sm-Yb), and (4) a slight negative $\mathrm{Nb}$ anomaly relative to $\mathrm{Th}$ and $\mathrm{La}$. The high-Ca boninite has higher $\mathrm{Ti}, \mathrm{Y}$, and $\mathrm{Yb}$, yet lower Th, than the low- and intermediate-Ca boninite.

Enrichment in large ion lithophile (LIL) elements relative to the high field strength (HFS) elements is a characteristic of magma generated above subduction zones. Although many LIL elements are sensitive to alteration, and the Leg 125 samples are pervasively altered, the LIL contents of the samples plotted in Figure 10B are probably close to their true values (see more detailed discussions in Murton et al., and Pearce et al., this volume). Microprobe analyses of potassium in the few fresh glasses further confirm that the source was enriched in the most mobile elements (van der Laan et al., and Newman and van der Laan, this volume). Figure 10B demonstrates the enrichment in the LIL elements $\mathrm{Sr}$ to $\mathrm{Th}$. No boninite has the high levels of LIL enrichment reached in the Mariana arc, however.

The positive $\mathrm{Sm}$ anomaly relative to $\mathrm{Zr}$ and $\mathrm{Hf}$ in the Mariana arc is also in marked contrast to the positive $\mathrm{Zr}$ (and $\mathrm{Hf}$ ) anomaly relative to $\mathrm{Sm}$ in the Leg 125 boninite. The positive $\mathrm{Zr}$ anomaly has been recognized as an important feature of some boninite samples by Sun and Nesbitt (1978), Cameron et al. (1983), Hickey-Vargas (1989), and others. The negative $\mathrm{Ti}$ anomaly relative to $\mathrm{Zr}$ in $\mathrm{Leg} 125$ boninite is also a well-known characteristic of boninite samples worldwide. Both these anomalies are more pronounced in the low-Ca and intermediate-Ca boninite from the volcanic edifice than in the intermediate-Ca and high-Ca boninite dikes.

\section{Isotopic Characteristics}

Pearce et al. (this volume) report the isotopic systematics of the Leg 125 samples. The plot of ${ }^{208} \mathrm{~Pb} /{ }^{204} \mathrm{~Pb}$ against ${ }^{206} \mathrm{~Pb} /{ }^{204} \mathrm{~Pb}$ (Fig. 11A) shows that the Eocene and early Oligocene samples from Leg 125 plot along the Northern Hemisphere Reference Line (NHRL), the line joining mid-ocean ridge and ocean island basalt compositions from the Northern Hemisphere (Hart, 1984). Note also that, unlike most volcanic arc basalts, they are not displaced toward pelagic sediment (PPS) compositions. The plot of $\mathrm{eNd}$ against ${ }^{206} \mathrm{~Pb} /{ }^{204} \mathrm{~Pb}$ (Fig. 11B) gives a similar mixing trend, suggesting that the $\mathrm{Pb}$ and $\mathrm{Nd}$ isotopes behave coherently. $\mathrm{As}$ in the $\mathrm{Pb}$ isotope diagram, the points lie on a line between Pacific MORB mantle (PMM) and Pacific Volcanogenic Sediment (PVS). Pearce et al. (this volume) infer from these plots that the isotope end-members lay in the Pacific, rather than Indian, mantle domain and that the depleted endmember resembles Pacific oceanic lithosphere. They also demonstrate that Leg 125 samples do not plot on the trend formed by samples dredged or drilled from the West Philippine Basin. The fact that the Leg 125 samples plot toward a PVS composition (data of Woodhead, 1989) need not imply that the mantle source was enriched by a component from subducted volcanogenic sediment. Because the volcanogenic sediment was derived from intraplate volcanic edifices, the sediment may have the same composition as the edifices themselves and, hence, the intraplate mantle might have a similar composition to PVS.

On projections involving $\mathrm{Sr}$ isotopes, such as $\mathrm{ENd}$ against $\mathrm{ESr}$ (Fig. 11C), the boninite samples form a trend that lies parallel to the line joining PMM with PVS but displaced to higher ESr values. The tholeiite samples from Site 782 are displaced to still more radiogenic $\mathrm{Sr}$ values. This figure suggests that an additional, possibly seawaterderived, component may be involved in the origin of the boninite and, even more so, the tholeiite samples. The same projection (shown on a larger scale in Fig. 11D) also is the most effective for highlighting the isotopic evidence for linkages between the various lithostratigraphic groups. Essentially there are four isotopic groups. Low-Ca boninite and low-Ca bronzite andesite from the base of Hole 786B have the most radiogenic $\mathrm{Sr}$ and form the first group. Intermediate- $\mathrm{Ca}$ boninite lavas from Hole 786B, intermediate-Ca bronzite andesite, andesite, dacite, and rhyolite form a second group. Late dikes of intermediate- $\mathrm{Ca}$ and high-Ca boninite together with intermediate- $\mathrm{Ca}$ boninites from the uppermost part of the edifice in Hole 786A form a third group. The tholeiites from Site 782 form the final group.

\section{Petrology of the Forearc Mantle Peridotites}

The refractory peridotite drilled from the Torishima Forearc and Conical seamounts represents the potential residue from the partial melting event that generated the boninitic magmas (Ishii et al., this volume). It thus provides an important part of our understanding of the early petrogenetic history of the Eocene forearc terrane. The 
Table 2. Summary of the characteristics of the various rock types recovered at Site 786.

\begin{tabular}{|c|c|c|c|c|}
\hline Rock type & Location in core & $\begin{array}{c}\text { Phenocrysts } \\
\text { (with } \% \text { and average composition) }\end{array}$ & $\begin{array}{l}\text { Major elements } \\
\quad \text { (average) }\end{array}$ & $\begin{array}{l}\text { Trace elements } \\
\text { (average) }\end{array}$ \\
\hline $\begin{array}{l}\text { Low-Ca boninite } \\
\text { (LCB) }\end{array}$ & $\begin{array}{c}55-63 \\
\text { (hyaloclastite } \\
\text { pillow lava } \\
\text { pillow breccia) }\end{array}$ & $\begin{array}{c}\text { ol }(5 \%)(\mathrm{Mg \#}=87) \\
\text { opx }(2-5 \%)(\mathrm{Mg \#}=84) \\
\text { cpx }(0-\text { tr. }) \\
\text { Cr Sp. (tr) }\end{array}$ & 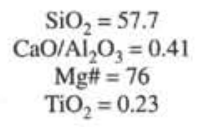 & $\begin{aligned} \mathrm{Zr} & =31 \\
\mathrm{Th} & =0.27 \\
\mathrm{Sr} & =102 \\
\mathrm{Ni} & =254\end{aligned}$ \\
\hline $\begin{array}{l}\text { Low-Ca bronzite } \\
\text { andesite (LCBrzA) }\end{array}$ & 68-72 (dikes) & $\begin{array}{c}\text { ol }(0-5 \%) \text { (altered) } \\
\text { opx }(0-20 \%) \text { (altered) } \\
\text { cpx (tr.) }(\mathrm{Mg} \#=82) \\
\text { plag. (tr.) }\end{array}$ & $\begin{array}{l}(\mathrm{An}=72) \\
\mathrm{CrSp} . \text { (tr.) }\end{array}$ & 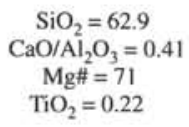 \\
\hline $\begin{array}{l}\text { Intermediate-Ca } \\
\text { boninite (ICB) }\end{array}$ & $\begin{array}{l}10-14 \text { (breccia) } \\
51-55 \text { (breccia) }\end{array}$ & $\begin{array}{c}\text { ol }(1-5 \%)(\mathrm{Mg \#}=86) \\
\text { opx }(6-20 \%)(\mathrm{Mg \#}=81) \\
\text { cpx }(2-4 \%)(\mathrm{Mg \#}=81) \\
\text { plag }(0-10 \%)(\mathrm{An}=80) \\
\mathrm{CrSp} .(\mathrm{tr})\end{array}$ & $\begin{array}{c}\mathrm{SiO}_{2}=56.2 \\
\mathrm{CaO} / \mathrm{Al}_{2} \mathrm{O}_{3}=0.56 \\
\mathrm{mg}^{\#}=69 \\
\mathrm{TiO}_{2}=0.23\end{array}$ & $\begin{array}{l}\mathrm{Zr}=35 \\
\mathrm{Th}=0.24 \\
\mathrm{Sr}=159 \\
\mathrm{Ni}=200\end{array}$ \\
\hline $\begin{array}{l}\text { Intermediate-Ca } \\
\text { bronzite andesite } \\
\text { (ICBrzA) }\end{array}$ & $\begin{array}{c}1-5 \text { (flow) } \\
10-14 \text { (breccia) } \\
27-32 \text { (flow) } \\
40-44 \text { (flow) } \\
44-51 \text { (breccia) }\end{array}$ & $\begin{array}{c}\text { ol }(0-1 \%)(\mathrm{Mg} \#=87) \\
\text { opx }(6-20 \%)(\mathrm{Mg} \#=81) \\
\operatorname{cpx}(3-10 \%)(\mathrm{Mg} \#=82) \\
\text { plag }(5-15 \%)(\mathrm{An}=72) \\
\text { Cr Sp. (tr.) }\end{array}$ & $\begin{array}{c}\mathrm{SiO}_{2} \\
\mathrm{CaO} / \mathrm{Al}_{2} \mathrm{O}_{3}=0.50 \\
\mathrm{mg} \mathrm{\#}=59 \\
\mathrm{TiO}_{2}=0.26 \mathrm{Ni}\end{array}$ & $\begin{array}{l}\mathrm{Zr}=38 \\
\mathrm{Th}=0.31 \\
\mathrm{Sr}=163 \\
\mathrm{Ni}=120\end{array}$ \\
\hline Andesite (A) & $\begin{array}{c}7-10 \text { (breccia) } \\
14-17 \text { (breccia) } \\
17-24 \text { (flow) }\end{array}$ & $\begin{array}{c}\text { opx (tr.) }(\mathrm{Mg \#}=75) \\
\text { cpx }(1-3 \%)(\mathrm{Mg \#}=76) \\
\text { plag }(3-5 \%)(\mathrm{An}=78) \\
\mathrm{mt}(\mathrm{tr} .)\end{array}$ & $\begin{array}{c}\mathrm{SiO}_{2}=60.1 \\
\mathrm{CaO} / \mathrm{Al}_{2} \mathrm{O}_{3}=0.40 \\
\mathrm{TiO}_{2}=0.31\end{array}$ & $\begin{array}{l}\mathrm{Zr}=51 \\
\mathrm{Th}=0.49 \\
\mathrm{Sr}=222 \\
\mathrm{Ni}=25\end{array}$ \\
\hline Dacite (D) & $\begin{array}{c}23-27 \\
\text { (flow/breccia) } \\
34-36 \text { (flow) }\end{array}$ & $\begin{array}{c}\text { opx }(0-5 \%)(\mathrm{Mg \#}=70) \\
\text { cpx }(0-2 \%)(\mathrm{Mg \#}=73) \\
\text { plag }(3-10 \%)(\mathrm{An}=74) \\
\mathrm{mt}(\mathrm{tr} .)\end{array}$ & $\begin{array}{c}\mathrm{SiO}_{2}=66.7 \\
\mathrm{CaO} / \mathrm{Al}_{2} \mathrm{O}_{3}=0.32 \\
\mathrm{TiO} 2=0.29\end{array}$ & $\begin{array}{c}\mathrm{Zr}=65 \\
\mathrm{Th}=0.57 \\
\mathrm{Sr}=203 \\
\mathrm{Ni}=12\end{array}$ \\
\hline Rhyolite (R) & $\begin{array}{c}21 \text { (flow) } \\
32-36 \text { (flow) } \\
61 \text { (dike) } \\
63-68 \text { (dikes) }\end{array}$ & $\begin{array}{c}\text { opx }(0-\text { tr. })(\mathrm{Mg} \#=52) \\
\text { cpx }(0-\mathrm{tr} .)(\mathrm{Mg \#}=57) \\
\text { plag }(0-3 \%)(\mathrm{An}=56) \\
\text { qtz }(3-10 \%) \\
\text { mt (tr. })\end{array}$ & $\begin{array}{c}\mathrm{SiO}_{2}=73.1 \\
\mathrm{CaO} / \mathrm{Al}_{2} \mathrm{O}_{3}=0.15 \\
\mathrm{TiO}_{2}=0.29\end{array}$ & $\begin{array}{c}\mathrm{Zr}=76 \\
\mathrm{Th}=0.70 \\
\mathrm{Sr}=115 \\
\mathrm{Ni}=5\end{array}$ \\
\hline $\begin{array}{l}\text { Intermediate-Ca } \\
\text { boninite (ICB- } \\
\text { late dikes \& 786A) }\end{array}$ & $\begin{array}{c}\text { 786A:16-19 } \\
\text { (breccia) } \\
\text { 786B: } 20,37,67,72 \\
\text { (dikes) }\end{array}$ & $\begin{array}{c}\text { ol }(1-5 \%)(\mathrm{Mg \#}=88) \\
\text { opx }(6-20 \%)(\mathrm{Mg \#}=86) \\
\text { cpx }(2-4 \%)(\mathrm{Mg}=84) \\
\text { plag }(0-10 \%) \\
\text { Cr Sp. (tr) }\end{array}$ & $\begin{array}{c}\mathrm{SiO}_{2}=54.6 \\
\mathrm{CaO} / \mathrm{Al}_{2} \mathrm{O}_{3}=0.60 \\
\mathrm{Mg} \#^{=}=72 \\
\mathrm{TiO}_{2}=0.25\end{array}$ & $\begin{aligned} \mathrm{Zr} & =29 \\
\mathrm{Th} & =0.16 \\
\mathrm{Sr} & =131 \\
\mathrm{Ni} & =266\end{aligned}$ \\
\hline $\begin{array}{l}\text { High-Ca boninite } \\
\text { (HCB) }\end{array}$ & $\begin{array}{c}5-6,21-22 \\
29,30,33,34 \\
40 \text { (all dikes) }\end{array}$ & $\begin{array}{c}\text { ol }(3-5 \%) \\
\text { opx (tr.) }(\mathrm{Mg \#}=82) \\
\text { cpx }(1-3 \%)(\mathrm{Mg \#}=85) \\
\text { plag (tr.) }(\mathrm{An}=79) \\
\text { Cr Sp. (tr.) }\end{array}$ & 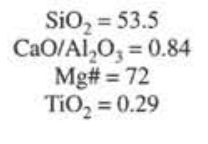 & $\begin{array}{c}\mathrm{Zr}=29 \\
\mathrm{Th}=0.15 \\
\mathrm{Sr}=137 \\
\mathrm{Ni}=242\end{array}$ \\
\hline
\end{tabular}

composition of the rocks recovered is summarized in Tables 3 and 4 . Harzburgite is the main rock type, together with subordinate dunite. It contains up to 2 modal percent of clinopyroxene. Spinels are chrome rich $(\mathrm{Cr} \#=40-80)$, olivine and orthopyroxene are highly magnesian $(\mathrm{Mg} \#=91-92.5)$, and the orthopyroxene contains low concentrations of $\mathrm{Al}_{2} \mathrm{O}_{3}$ (mostly 1-2 wt\%). In keeping with such a refractory composition, the bulk harzburgites have concentrations of $\mathrm{Al}_{2} \mathrm{O}_{3}$ and $\mathrm{CaO}$ below $1 \mathrm{wt} \%$. With rare exceptions, all rocks underwent at least $60 \%$ serpentinization.

Figure $12 \mathrm{~A}$ illustrates two key aspects of the mineral analyses presented by Ishii et al. (this volume), the $\mathrm{Cr} \#$ of the spinels and the forsterite content of the olivines. This projection is that used by Bonatti and Michael (1989) to compare peridotite from different settings. We have plotted their fields and data points for peridotites from mid-ocean ridges (abyssal peridote), the Red Sea incipient rift, and Tonga and Mariana forearcs. Chrome spinel from the Leg 125 peridotite has higher chrome numbers than spinel from most abyssal peridotite, confirming the more refractory nature of its host rocks (Dick and Bullen, 1984). The olivine from the Leg 125 peridotites is, for a similar reason, more magnesian than olivine from the abyssal peridotite. The plot of $\mathrm{Al}_{2} \mathrm{O}_{3}$ and $\mathrm{CaO}$ (Ishii et al., this volume) is given as Figure 12B to highlight the concentrations of these elements compared with abyssal peridotite. The Leg 125 peridotite thus most closely resembles peridotite from supra-subduction zone settings. Although this is a rather obvious conclusion in view of the present-day setting of these peridotites, it does confirm that they are likely to be residues of melting above the subduction zone and thus not accreted or "trapped" fragments of oceanic lithosphere of the Philippine or Pacific Plates.

\section{Trace Element Geochemistry of Forearc Mantle Peridotites}

Parkinson et al. (this volume) describe the trace element geochemistry of the peridotites and their host minerals. These data are summarized in Tables 3 and 4. Some representative chondrite-normalized REE patterns, extended also to include $\mathrm{Rb}, \mathrm{Sr}, \mathrm{Zr}$, Ti, and $\mathrm{Y}$, are shown in Figure 13A. The basic REE pattern is $\mathrm{U}$-shaped with highly variable $(\mathrm{La} / \mathrm{Sm})_{n}$ ratios in the 5-250 range and $(\mathrm{Sm} / \mathrm{Yb})_{n}$ ratios in the $0.05-0.25$ range. These patterns are in marked contrast to those of most abyssal peridotite samples, which contain higher HREE contents and are LREE-depleted. They have the same form as many 

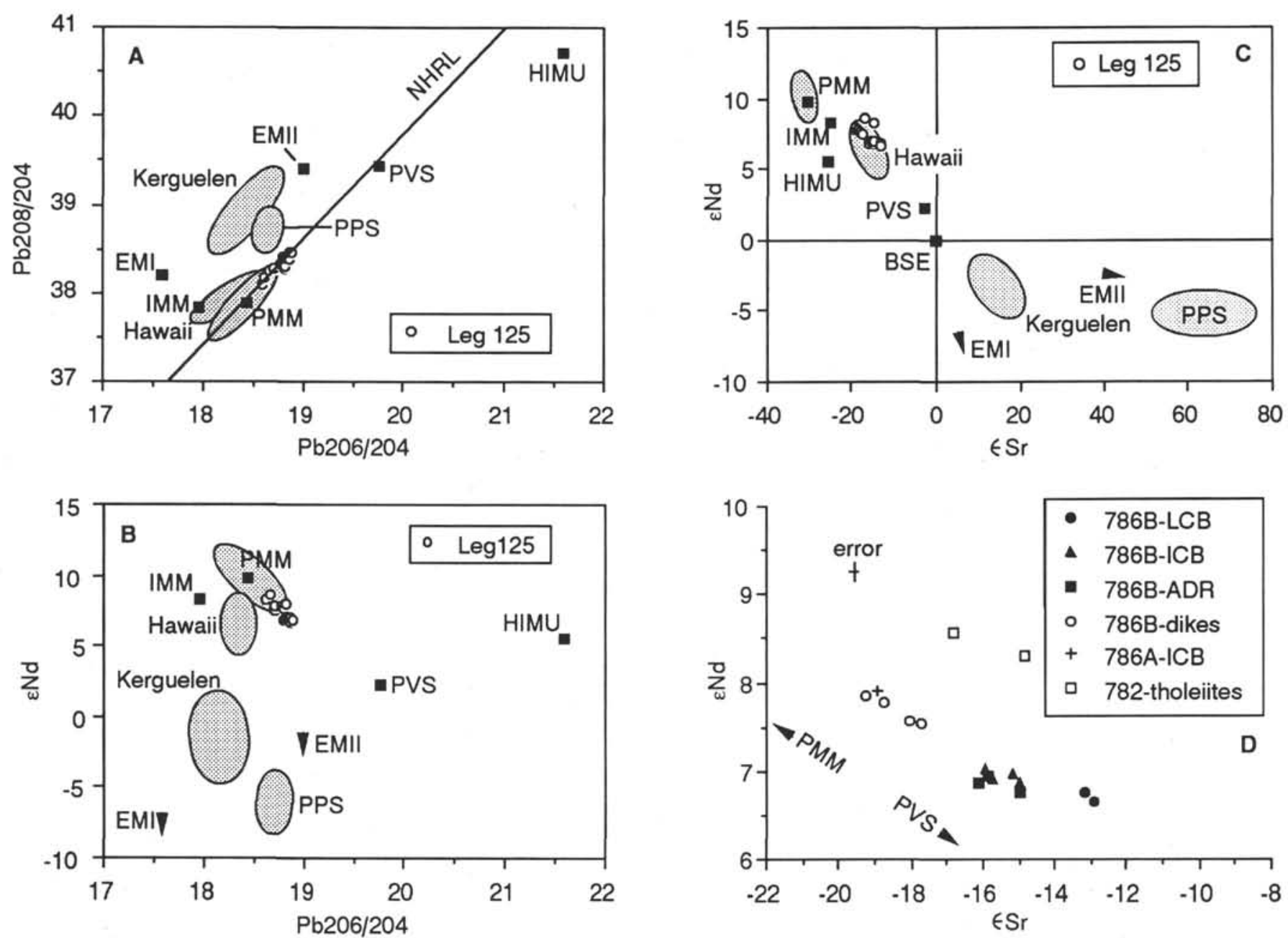

Figure 11. Main isotope covariation diagrams showing the distribution of data from Leg 125 boninites in comparison to fields and points for the nearest major hot-spots (Hawaii and Kerguelen), Pacific MORB mantle (PMM), Indian MORB mantle (IMM), Pacific Pelagic Sediment (PPS), and Pacific Volcanogenic Sediment (PVS) and the isotope "end-members" EMI, EMII, and HIMU (for details and data sources, see Pearce et al., this volume).

forearc boninite samples, but their U-shape is more pronounced than any patterns published to date.

Of the other elements, $\mathrm{Sr}$ and $\mathrm{Zr}$ give marked positive anomalies with respect to the basic U-shaped REE pattern. Compared with average abyssal peridotite, these patterns demonstrate (1) lower levels of the HREEs, (2) enrichment in the LREEs, $\mathrm{Rb}, \mathrm{Nb}, \mathrm{Sr}, \mathrm{Zr}, \mathrm{Sm}$, and Eu relative to $\mathrm{Ti}$ and the HREEs, and (3) enrichment in $\mathrm{Sr}$ and $\mathrm{Zr}$ relative to their adjacent REEs. The shaded band in Figure 13 gives the modeled pattern for an abyssal peridotite of equivalent depletion to the Leg 125 peridotite. The difference between the modeled and observed patterns highlights the nature and extent of the enrichment shown by the elements on the LHS of the pattern.

Parkinson et al. (this volume) also publish extended patterns for clinopyroxenes, two typical examples of which are presented in Figure 14. These again highlight the enrichment in LREEs, $\mathrm{Zr}$ and $\mathrm{Sr}$ compared with abyssal peridotites. The similarity in enrichment pattern between the whole rocks and the clinopyroxenes provides the important evidence that this enrichment is a primary phenomenon rather than a product of the serpentinization process.

\section{CONSTRAINTS ON MAGMA GENESIS 1: THE MANTLE COMPOSITION BEFORE SUBDUCTION}

Petrologists have reached a consensus (see papers in Crawford, 1989) that boninite is the product of partial melting of a peridotite source that has already undergone one or more episodes of partial melting. The most common scenario may be an initial melting event at a mid-ocean ridge followed by remelting of the residual oceanic mantle above a subduction zone. However, melting and remelting in other settings also are plausible. The aim of this section is to investigate the degree of depletion of the sources of Leg 125 boninite and the nature of any metasomatic events that might have re-enriched the source prior to subduction. This information enables us to infer the location and nature of the first melting event.

\section{Phase Diagram Evidence for the Depletion of the Boninite Mantle Sources Before Subduction}

Several methods exist for investigating the nature of the mantle source before the subduction component is added. A graphical method, pioneered by Green (1970) and Falloon et al. (1988) and applied to boninite genesis by Crawford et al. (1989) and Falloon et al. (1989), is to plot the normative compositions of estimated primary boninite melts as projections from diopside onto the base (Jd+CaTs-Qz-OI) of the basalt tetrahedron and as projections from plagioclase onto the face $(\mathrm{Ol}-\mathrm{Di}-\mathrm{Qz})$ of the tetrahedron. These diagrams constrain the mantle source of a boninite because a primary boninite melt must lie above the line of orthopyroxene elimination, as denoted by extrapolation of a line from olivine to the postulated source composition. The projection from plagioclase is given as Figure 15. The authors cited above use this projection to demonstrate that the field of published low-Ca boninite data plots below the line of orthopyroxene elimina- 
Table 3. Table of analysis of representative samples from Leg 125. See Table 2 for the abbreviations to the rock types from Site $786 .^{a}$

\begin{tabular}{|c|c|c|c|c|c|c|c|c|c|c|c|c|c|}
\hline & $786 \mathrm{~B}$ & $786 \mathrm{~B}$ & $786 \mathrm{~B}$ & $786 \mathrm{~B}$ & $786 \mathrm{~B}$ & $786 \mathrm{~B}$ & $786 \mathrm{~B}$ & $786 \mathrm{~B}$ & $786 \mathrm{~B}$ & $782 \mathrm{~A}$ & $782 \mathrm{~A}$ & $780 \mathrm{C}$ & $784 \mathrm{~A}$ \\
\hline Core & $62 \mathrm{R}-3$ & $70 \mathrm{R}-1$ & $11 \mathrm{R}-1$ & IR-1 & $19 \mathrm{R}-1$ & $35 R-1$ & $66 \mathrm{R}-1$ & $67 \mathrm{R}-1$ & $40 \mathrm{R}-2$ & $50 X-1$ & $45 X-1$ & $6 \mathrm{R}-1$ & $36 \mathrm{R}-1$ \\
\hline Interval (cm) & $40-42$ & $68-73$ & $122-126$ & $61-64$ & 91-94 & $73-76$ & $88-90$ & $56-59$ & $54-57$ & $37-42$ & $32-35$ & $61-62$ & $107-109$ \\
\hline Unit & IV-27 & IV -33 & IV -4 & IV-1 & IV-6 & IV -20 & IV-29 & IV -32 & IV-23 & II & II & II & II \\
\hline Magma type & LCB & LCBrzA & ICB & ICBrzA & A & D & $\mathrm{R}$ & ICB & HCB & ThA & ThD & $\mathrm{Hz}$ & Dunite \\
\hline $\mathrm{SiO}_{2}$ & 53.47 & 58.44 & 53.64 & 60.11 & 58.13 & 64.80 & 68.95 & 53.00 & 47.23 & 56.10 & 66.97 & 40.7000 & 33.0100 \\
\hline $\mathrm{TiO}_{2}$ & 0.20 & 0.23 & 0.22 & 0.21 & 0.29 & 0.28 & 0.26 & 0.25 & 0.31 & 0.78 & 0.45 & 0.0013 & 0.0011 \\
\hline $\mathrm{Al}_{2} \mathrm{O}_{3}$ & 12.05 & 11.43 & 12.89 & 12.39 & 16.25 & 14.72 & 13.41 & 12.46 & 12.06 & 14.96 & 14.25 & 0.47 & 0.20 \\
\hline $\mathrm{Fe}_{2} \mathrm{O}_{3}$ & 8.47 & 6.15 & 7.62 & 7.03 & 7.49 & 5.39 & 4.07 & 7.54 & 8.05 & 10.92 & 4.05 & 7.91 & 8.90 \\
\hline $\mathrm{MnO}$ & 0.13 & 0.13 & 0.14 & 0.11 & 0.12 & 0.04 & 0.08 & 0.14 & 0.14 & 0.15 & 0.10 & 0.11 & 0.13 \\
\hline $\mathrm{MgO}$ & 13.04 & 7.40 & 10.88 & 7.80 & 3.57 & 2.36 & 0.82 & 13.08 & 11.40 & 3.59 & 0.68 & 42.94 & 40.31 \\
\hline $\mathrm{CaO}$ & 5.27 & 4.95 & 6.50 & 6.09 & 7.14 & 5.00 & 2.26 & 6.70 & 11.90 & 7.85 & 3.37 & 0.60 & 0.14 \\
\hline $\mathrm{Na}_{2} \mathrm{O}$ & 3.19 & 3.23 & 2.73 & 3.06 & 3.13 & 3.82 & 3.70 & 2.76 & 2.12 & 3.35 & 3.95 & & \\
\hline $\mathrm{K}_{2} \mathrm{O}$ & 0.67 & 0.20 & 0.42 & 0.51 & 0.71 & 0.69 & 3.12 & 0.21 & 0.26 & 0.51 & 1.08 & & \\
\hline $\mathrm{P}_{2} \mathrm{O}_{5}$ & 0.03 & 0.04 & 0.01 & 0.02 & 0.04 & 0.08 & 0.08 & 0.04 & 0.04 & 0.07 & 0.07 & & \\
\hline LOI & 4.33 & 4.66 & 2.80 & 2.19 & 2.34 & 1.23 & 2.36 & 2.56 & 5.46 & 1.56 & 3.49 & 5.28 & 16.34 \\
\hline Total & 100.85 & 96.86 & 97.85 & 99.52 & 99.21 & 98.41 & 99.11 & 98.74 & 98.97 & 99.84 & 98.46 & 98.01 & 99.03 \\
\hline $\mathrm{Sc}$ & 29.0 & 27.6 & 29.2 & 24.9 & 20.8 & 20.4 & 11.8 & 33.7 & 27.1 & 31.0 & 12.7 & 8.6 & 3.6 \\
\hline $\mathrm{Cr}$ & 1036 & 670 & 543 & 384 & 12 & 51 & 33 & 786 & 762 & 13 & & 2249 & 2380 \\
\hline V & 166 & 148 & 171 & 177 & 226 & 152 & 31 & 202 & 193 & 286 & 32 & 27 & 14 \\
\hline $\mathrm{Ni}$ & 306 & 202 & 157 & 115 & 22 & 26 & 9 & 296 & 374 & 14 & 3 & 2350 & 2858 \\
\hline $\mathrm{Co}$ & 45.0 & 32.0 & 36.3 & 29.1 & 19.1 & 13.9 & 5.6 & 38.5 & 44.6 & 21.0 & 4.0 & 118 & 122 \\
\hline $\mathrm{Cu}$ & 60 & 70 & 40 & 66 & 83 & 34 & 50 & 56 & 27 & 60 & 11 & 4 & 3 \\
\hline $\mathrm{Zn}$ & 63 & 77 & 71 & 55 & 72 & 48 & 92 & 58 & 57 & 75 & 104 & 37 & 38 \\
\hline $\mathrm{Rb}$ & 6.4 & 1.5 & 5.7 & 5.8 & 7.7 & 9.1 & 29.0 & 3.1 & 7.6 & 8.3 & 17.6 & 0.29 & 0.036 \\
\hline $\mathrm{Sr}$ & 107 & 144 & 165 & 166 & 215 & 222 & 104 & 136 & 139 & 188.4 & 160 & 2.5 & 4.1 \\
\hline $\mathrm{Y}$ & 7.2 & 8.9 & 5.1 & 6.7 & 9.2 & 10.1 & 10.7 & 6.5 & 8.2 & 16.1 & 19.8 & 0.015 & 0.018 \\
\hline $\mathrm{Zr}$ & 35 & 45 & 40 & 45 & 49 & 62 & 81 & 27 & 26 & 61 & 100 & 0.214 & 0.095 \\
\hline $\mathrm{Nb}$ & 0.53 & 0.65 & 0.62 & 0.70 & 0.74 & 1.03 & 0.98 & 0.44 & 0.53 & 0.51 & 0.78 & & \\
\hline $\mathrm{Ba}$ & 47 & 50 & 19 & 36 & 31 & 62 & 388 & 7.6 & 15 & 21 & 35 & & \\
\hline $\mathrm{La}$ & 1.81 & 2.62 & 1.31 & 1.77 & 2.55 & 3.02 & 3.60 & 1.15 & 1.50 & 2.01 & 4.47 & 0.118 & 0.035 \\
\hline $\mathrm{Ce}$ & 3.86 & 5.52 & 3.37 & 3.90 & 5.25 & 6.46 & 8.10 & 2.57 & 3.05 & 5.83 & 10.7 & 0.037 & 0.050 \\
\hline Pr & 0.59 & 0.80 & 0.48 & 0.57 & 0.82 & 0.96 & 1.41 & 0.37 & 0.50 & 0.97 & 1.92 & & \\
\hline $\mathrm{Nd}$ & 2.84 & 3.65 & 2.32 & 2.62 & 3.90 & 4.64 & 5.90 & 1.97 & 2.61 & 5.30 & 9.66 & 0.008 & 0.023 \\
\hline $\mathrm{Sm}$ & 0.81 & 0.97 & 0.61 & 0.79 & 1.14 & 1.24 & 1.39 & 0.61 & 0.80 & 1.72 & 2.56 & 0.0013 & 0.0009 \\
\hline $\mathrm{Eu}$ & 0.27 & 0.34 & 0.24 & 0.26 & 0.38 & 0.39 & 0.46 & 0.22 & 0.31 & 0.64 & 0.74 & 0.0006 & 0.0003 \\
\hline Gd & 0.97 & 1.20 & 0.78 & 0.88 & 1.38 & 1.59 & 2.16 & 0.81 & 1.06 & 2.21 & 3.03 & 0.0015 & 0.0013 \\
\hline $\mathrm{Tb}$ & 0.16 & 0.21 & 0.14 & 0.15 & 0.24 & 0.24 & 0.26 & 0.15 & 0.20 & 0.34 & 0.54 & & \\
\hline Dy & 1.05 & 1.21 & 0.84 & 0.95 & 1.61 & 1.49 & 1.82 & 1.00 & 1.30 & 2.50 & 3.44 & 0.0014 & 0.0028 \\
\hline Ho & 0.23 & 0.27 & 0.17 & 0.20 & 0.29 & 0.32 & 0.38 & 0.21 & 0.30 & 0.47 & 0.68 & & \\
\hline Er & 0.69 & 0.77 & 0.56 & 0.64 & 0.98 & 1.03 & 1.21 & 0.72 & 0.84 & 1.53 & 2.07 & 0.0025 & 0.0080 \\
\hline $\mathrm{Tm}$ & 0.11 & 0.14 & 0.10 & 0.11 & 0.14 & 0.16 & 0.18 & 0.12 & 0.14 & 0.24 & 0.31 & & \\
\hline $\mathrm{Yb}$ & 0.80 & 0.92 & 0.70 & 0.70 & 0.99 & 1.04 & 1.17 & 0.75 & 0.87 & 1.59 & 2.08 & 0.0128 & 0.0167 \\
\hline $\mathrm{Lu}$ & 0.14 & 0.15 & 0.11 & 0.12 & 0.16 & 0.15 & 0.19 & 0.11 & 0.13 & 0.27 & 0.3 & 0.0021 & 0.0018 \\
\hline $\mathrm{Hf}$ & 0.90 & 1.15 & 1.02 & 1.16 & 1.29 & 1.67 & 2.10 & 0.70 & 0.70 & 1.68 & 2.80 & & \\
\hline $\mathrm{Ta}$ & 0.03 & 0.05 & 0.03 & 0.05 & 0.04 & 0.06 & 0.08 & 0.03 & 0.02 & 0.05 & 0.07 & & \\
\hline $\mathrm{Pb}$ & 1.50 & 4.66 & 2.37 & 1.78 & 1.79 & 2.24 & 3.19 & 0.72 & 0.84 & 1.74 & 2.76 & & \\
\hline Th & 0.27 & 0.31 & 0.34 & 0.34 & 0.46 & 0.55 & 0.67 & 0.17 & 0.18 & 0.20 & 0.40 & & \\
\hline $\mathrm{U}$ & 0.18 & 0.26 & 0.13 & 0.18 & 0.19 & 0.27 & 0.37 & 0.12 & 0.14 & 0.20 & 0.21 & & \\
\hline \multicolumn{14}{|c|}{ Chondrite normalized } \\
\hline $\mathrm{La}$ & 5.84 & 8.45 & 4.23 & 5.71 & 8.23 & 9.74 & 11.61 & 3.71 & 4.84 & 6.48 & 14.42 & 0.381 & 0.113 \\
\hline $\mathrm{Ce}$ & 4.78 & 6.83 & 4.17 & 4.83 & 6.50 & 8.00 & 10.02 & 3.18 & 3.77 & 7.22 & 13.24 & 0.046 & 0.062 \\
\hline $\mathrm{Pr}$ & 4.84 & 6.56 & 3.93 & 4.67 & 6.72 & 7.87 & 11.56 & 3.03 & 4.10 & 7.95 & 15.74 & & \\
\hline $\mathrm{Nd}$ & 4.73 & 6.08 & 3.87 & 4.37 & 6.50 & 7.73 & 9.83 & 3.28 & 4.35 & 8.83 & 16.10 & 0.013 & 0.038 \\
\hline $\mathrm{Sm}$ & 4.15 & 4.97 & 3.13 & 4.05 & 5.85 & 6.36 & 7.13 & 3.13 & 4.10 & 8.82 & 13.13 & 0.007 & 0.005 \\
\hline Eu & 3.67 & 4.63 & 3.27 & 3.54 & 5.17 & 5.31 & 6.26 & 2.99 & 4.22 & 8.71 & 10.07 & 0.008 & 0.004 \\
\hline Gd & 3.75 & 4.63 & 3.01 & 3.40 & 5.33 & 6.14 & 8.34 & 3.13 & 4.09 & 8.53 & 11.70 & 0.006 & 0.005 \\
\hline $\mathrm{Tb}$ & 3.38 & 4.43 & 2.95 & 3.16 & 5.06 & 5.06 & 5.49 & 3.16 & 4.22 & 7.17 & 11.39 & & \\
\hline Dy & 3.26 & 3.76 & 2.61 & 2.95 & 5.00 & 4.63 & 5.65 & 3.11 & 4.04 & 7.76 & 10.68 & 0.004 & 0.009 \\
\hline Ho & 3.20 & 3.76 & 2.37 & 2.79 & 4.04 & 4.46 & 5.29 & 2.92 & 4.18 & 6.55 & 9.47 & & \\
\hline Er & 3.29 & 3.67 & 2.67 & 3.05 & 4.67 & 4.90 & 5.76 & 3.43 & 4.00 & 7.29 & 9.86 & 0.012 & 0.038 \\
\hline $\mathrm{Tm}$ & 3.40 & 4.32 & 3.09 & 3.40 & 4.32 & 4.94 & 5.56 & 3.70 & 4.32 & 7.41 & 9.57 & & \\
\hline $\mathrm{Yb}$ & 3.83 & 4.40 & 3.35 & 3.35 & 4.74 & 4.98 & 5.60 & 3.59 & 4.16 & 7.61 & 9.95 & 0.061 & 0.080 \\
\hline $\mathrm{Lu}$ & 4.35 & 4.66 & 3.42 & 3.73 & 4.97 & 4.66 & 5.90 & 3.42 & 4.04 & 8.39 & 9.32 & 0.065 & 0.056 \\
\hline
\end{tabular}

${ }^{2} \mathrm{Th} A=$ tholeiitic andesite, $\mathrm{ThD}=$ tholeiitic dacite, $\mathrm{Hz}=$ harzburgite. Missing values were not detected. Oxides are in wt $\%$ and trace elements in parts per million. For analytical techniques and full tables, see Arculus et al., Murton et. al., and Parkinson et, al. (this volume). 
Table 4. Summary of the characteristics of the various rock types recovered at Sites 778-780 and 783-784.

\begin{tabular}{|c|c|c|}
\hline Location/rock type & Bulk rock composition & Mineral composition \\
\hline $\begin{array}{l}\text { 778A } \\
\text { (Cores 5-13) } \\
\text { harzburgite } \\
\text { metabasalt }\end{array}$ & $\begin{array}{c}\mathrm{Al}_{2} \mathrm{O}_{3}=0.1 \%-1 \% \\
\mathrm{CaO}=0 \%-3.5 \% \\
\text { (but generally }<0.1 \% \text { ) }\end{array}$ & $\begin{array}{c}\text { sp: } \mathrm{Cr} \#=0.34-0.69 \\
\text { ol: } \mathrm{Fo}=92.2 \%-93.6 \% \\
\text { opx: } \mathrm{Al}=0.90-3.34 \% \\
\text { cpx: } \mathrm{Ca}=.230-.250\end{array}$ \\
\hline $\begin{array}{l}\text { 779A } \\
\text { (Cores 3-26) } \\
\text { harzburgite } \\
\text { dunite } \\
\text { metabasalt }\end{array}$ & $\begin{array}{c}\mathrm{Al}_{2} \mathrm{O}_{3}=0.21-0.77 \\
\mathrm{CaO}=0.08 \%-0.55 \% \text { (hz.) } \\
\mathrm{Al}_{2} \mathrm{O}_{3}=0.07-0.63 \% \\
\mathrm{CaO}=0.1 \%-0.6 \% \text { (dunite) }\end{array}$ & $\begin{array}{c}\text { sp: } \mathrm{Cr} \#=0.41-0.81 \\
\text { ol: } \mathrm{Fo}=91.2 \%-92.3 \% \\
\text { opx: } \mathrm{Al}_{2} \mathrm{O}_{3}=0.47 \%-2.69 \% \\
\text { cpx: } \mathrm{Ca}=0.214-0.248\end{array}$ \\
\hline $\begin{array}{l}780 \mathrm{C} \\
\text { (Cores 3-18) } \\
\text { harzburgite } \\
\text { dunite }\end{array}$ & $\begin{array}{c}\mathrm{Al}_{2} \mathrm{O}_{3}=0.47-0.66 \% \\
\mathrm{CaO}=0.60 \%-0.89 \% \text { (hz.) } \\
\mathrm{Al}_{2} \mathrm{O}_{3}=0.65 \% \\
\mathrm{CaO}=0.11 \% \text { (dunite) }\end{array}$ & $\begin{array}{c}\text { sp: } \mathrm{Cr} \#=0.46-0.57 \\
\text { ol: } \mathrm{Fo}=91.4 \%-92.1 \% \\
\text { opx: } \mathrm{Al}_{2} \mathrm{O}_{3}=0.95 \%-2.48 \% \\
\text { cpx: } \mathrm{Ca}=0.229-0.248\end{array}$ \\
\hline $\begin{array}{l}\text { 783A } \\
\text { (Cores 14-18) } \\
\text { harzburgite } \\
\text { metabasalt }\end{array}$ & $\begin{array}{l}\mathrm{Al}_{2} \mathrm{O}_{3}=0.35-0.59 \% \\
\mathrm{CaO}=0.31 \%-1.66 \%\end{array}$ & $\begin{array}{c}\text { sp: } \mathrm{Cr} \#=0.46-0.59 \\
\text { ol: } \mathrm{Fo}=91.1 \%-92.0 \% \\
\text { opx: } \mathrm{Al}_{2} \mathrm{O}_{3}=0.63 \%-3.73 \% \\
\text { cpx: } \mathrm{Ca}=0.216-0.247\end{array}$ \\
\hline $\begin{array}{l}\text { 784A } \\
\text { (Cores 35-45) } \\
\text { harzburgite } \\
\text { dunite } \\
\text { metabasalt }\end{array}$ & $\begin{array}{c}\mathrm{Al}_{2} \mathrm{O}_{3}=0.27-0.62 \\
\mathrm{CaO}=0.06 \%-0.58 \% \text { (harz.) } \\
\mathrm{Al}_{2} \mathrm{O}_{3}=0.12 \%-0.34 \% \\
\mathrm{CaO}=0.08 \%-0.17 \% \text { (dunite) }\end{array}$ & $\begin{array}{c}\text { sp: } \mathrm{Cr} \#=0.53-0.68 \\
\text { ol: } \mathrm{Fo}=91.7 \%-92.5 \% \\
\text { opx: } \mathrm{Al}_{2} \mathrm{O}_{3}=0.95 \%-2.06 \% \\
\text { cpx } \mathrm{Ca}=0.227-0.248\end{array}$ \\
\hline
\end{tabular}

tion, thus implying that the low-Ca boninite primary melts must have been derived from sources that were more depleted than the Tinaquillo lherzolite. They make the point that because the Tinaquillo lherzolite itself is more depleted than a MORB source, the boninites must be derived from a source from which a significant proportion of melt has already been extracted.

Application of this projection to Leg 125 samples is difficult because of the absence of fresh, primitive glass, the abundance of phenocrysts in the most primitive boninites, and the effects of alteration. Moreover, the enrichment of the source in sodium, and possibly aluminum, as discussed in the section on source enrichment, increases normative albite at the expense of normative quartz. Of the large quantity of samples analyzed for major elements (Arculus et al., this volume), few satisfy the criteria for primitive melts (no element mobility, liquid compositions, high magnesium numbers). The high$\mathrm{Ca}$ boninite group provides no suitable composition because of its high proportion of olivine phenocrysts and the fact that these phenocrysts are replaced by carbonate and oxide, making its $\mathrm{MgO}$ and $\mathrm{CaO}$ contents unreliable. Several low-Ca and intermediate-Ca boninite samples may have compositions close to primitive melts. Examples are listed in Table 5. Their compositions are calculated in several ways: (1) volatile-free; (2) phenocryst-free, assuming that all the phenocrysts are of cumulate origin; (3) phenocryst-free and sodium (and potassium)-corrected; (4) aluminum- as well as sodiumcorrected. The sodium correction assumes that the boninite compositions would have lain on an extrapolation of the $\mathrm{Na}_{2} \mathrm{O}-\mathrm{TiO}_{2}$ correlation for primitive MORB (Fig. 20A), had the mantle not been enriched in this element. The aluminum correction assumes that the aluminum content before subduction would have lain on an extrapolation of the $\mathrm{CaO} / \mathrm{Al}_{2} \mathrm{O}_{3}-\mathrm{TiO}_{2}$ correlation for MORB (Fig. 20B). Table 5 indicates that reducing the sodium content but leaving aluminum unchanged gives normative corundum in the low-Ca boninite. From this, we can infer that the boninite mantle source was enriched in aluminum as well as sodium.

The projections from plagioclase for these possible primary boninite liquid compositions are shown in Figure 15 together with the reference compositions of the Tinaquillo lherzolite and an average Leg 125 harzburgite. This figure also shows the locus of points
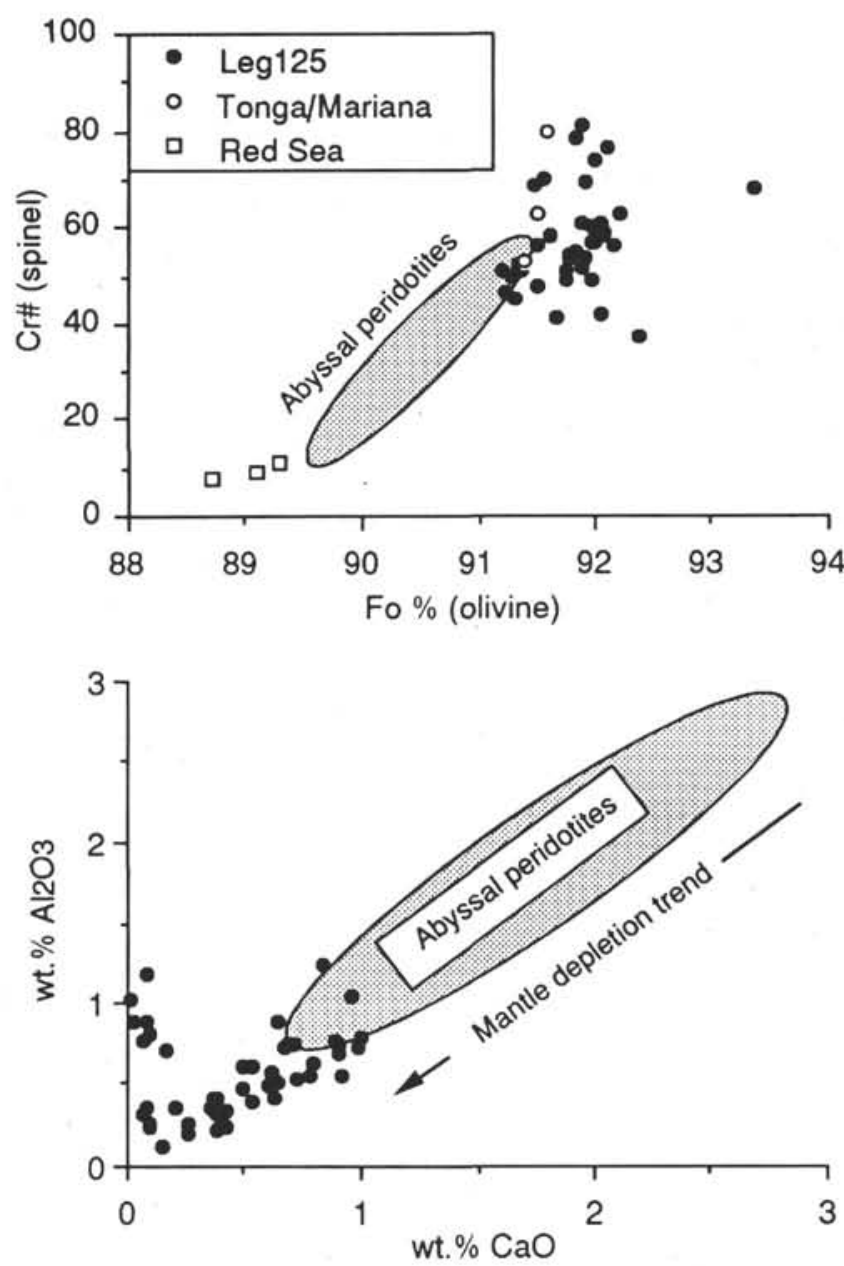

Figure 12. Diagrams showing the composition of the forearc harzburgites in comparison to other peridotites. The data and further discussion are given in Ishii et al. (this volume).

marking clinopyroxene and orthopyroxene elimination for equilibrium melting at different pressures. The figure also contains some olivine-clinopyroxene-orthopyroxene and olivine-orthopyroxene equilibrium cotectics experimentally determined for the Tinaquillo lherzolite at different pressures (e.g., Crawford et al., 1989; Falloon et al., 1989). These cotectics are not strictly relevant to fractional melting and the pooling of melt fractions, but they do form a useful frame of reference. Of the three groups of data points plotted (phenocryst-free, sodium-corrected, sodium + aluminum-corrected), the latter two probably best bracket the true composition of the primary melt that would have been produced from the source before the metasomatic event. Several conclusions can be drawn from this diagram. (1) The low-Ca boninite lies below the line of orthopyroxene elimination for the Tinaquillo lherzolite. Therefore, it must have been produced by melting of a source that is more depleted than the Tinaquillo lherzolite composition. (2) The intermediate-Ca boninite could have been generated from a source similar to the Tinaquillo lherzolite if the degree of melting had been sufficiently high to eliminate clinopyroxene. Alternatively, it may have been produced by less melting of a more depleted source than the Tinaquillo lherzolite. (3) The two primary magmas are not related by any partial melting or fractional crystallization trend and probably were derived from sources characterized by different degrees of depletion. (4) The positions of the data points to the right of the diopside-hypersthene join indicate that melting of orthopyroxene was incongruent in both cases. (5) The data set recalculated assuming sodium and aluminum addition to the boninite 

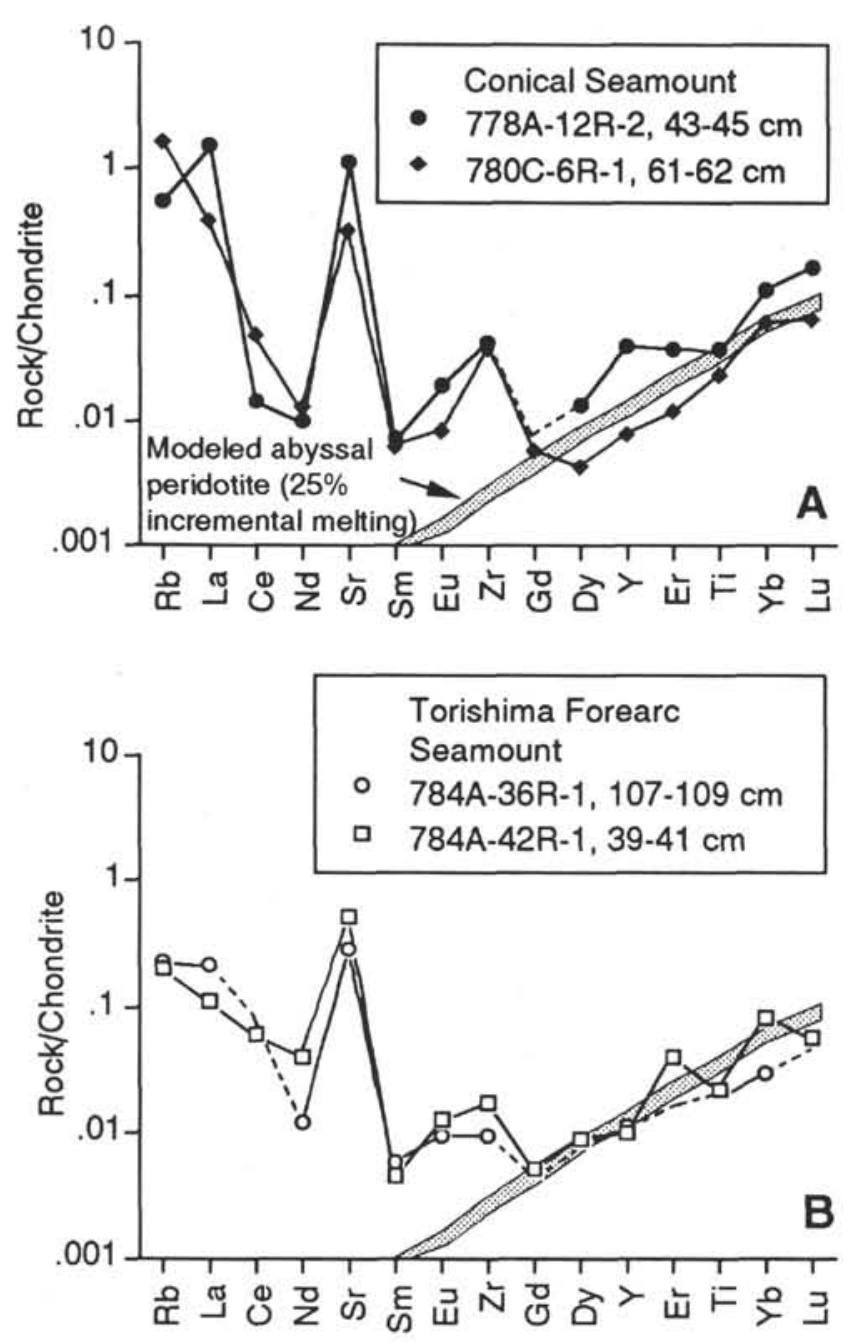

Figure 13. Extended REE patterns for some peridotites from Conical Seamount and Torishima Forearc Seamount (from Parkinson et al., this volume). The shaded band is the modeled composition of a highly depleted abyssal peridotite. The stippled region indicates possible subduction zone enrichment. The diagram thus highlights the enrichment in the harzburgite of elements $\mathrm{Rb}$ to $\mathrm{Zr}$.

source is most consistent with the position of the low-pressure cotectics and with the fields for other boninite suites.

\section{Geochemical Evidence for the Depletion of the Boninite Mantle Sources Before Subduction}

A different perspective is provided by plotting a compatible against an incompatible element. In this type of plot, the incompatible element has to be one that is not added in the subduction component, so that variable source enrichment is not a factor. Typically Ti, Y, or the heavy REE is used as the incompatible element, $\mathrm{Cr}, \mathrm{Ni}$, or $\mathrm{Mg} \#$ (or Sc or V) as the compatible element (Pearce, 1980; Pearce et al., 1984). Murton et al. (this volume) use $\mathrm{Cr}$ as the incompatible element and $\mathrm{Ti}$ and $\mathrm{Y}$ as the compatible elements. Ti is the most depleted element (see Fig. 10) and, hence, least likely to have been added to the source. $\mathrm{Ti}$ therefore has been adopted as the incompatible element. $\mathrm{Mg} \#$ has been chosen as a compatible "element" to enable experimental data to be plotted on the same diagram (Fig. 16).

On this diagram, the range of potential mantle compositions forms a subhorizontal trend outlined by the fertile MORB mantle (FMM) estimate and the field of abyssal peridotites (e.g., Dick, 1989). Leg 125

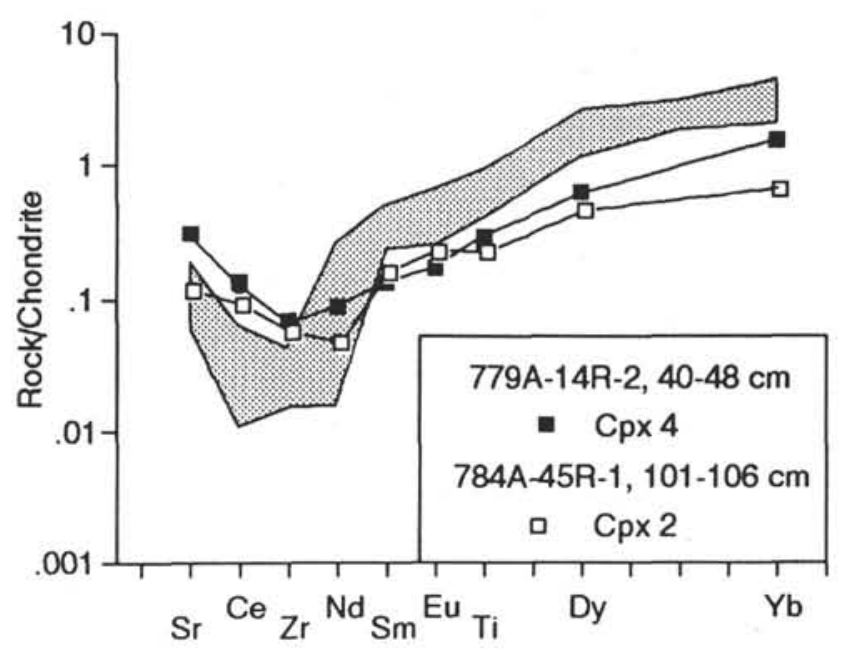

Figure 14. Extended REE patterns for some clinopyroxenes from Conical Seamount and Torishima Forearc Seamount (from Parkinson et al., this volume). The shaded area gives the range of patterns for depleted abyssal peridotites (Johnson et al., 1989). The stippled region indicates possible subduction zone enrichment.

harzburgite samples (using the accurate Ti data of Parkinson et al. (this volume) and correcting for changes in $\mathrm{Mg} \#$ caused by serpentinization) plot as an extension of this trend to more depleted compositions. Trace element modeling has shown that equilibrium melting is unable to account for the degree of incompatible element (including Ti) depletion in abyssal peridotite (Johnson et al., 1989) and the same conclusion holds for Leg 125 peridotite (Parkinson et al., this volume). Fractional melting, or incremental melting with small increments ( $<1 \%$ by mass), best fits the observed data, in keeping with theoretical models of melt extraction (McKenzie, 1984). We have superimposed a modeled mantle depletion curve, annotated according to percentage of melt lost, on the fields of observed data using the fractional melting equation. According to this model, the Leg 125 peridotite samples are residues from about $25 \%$ of melting. Note, however, that the calibration of this trend depends on the choice of melting rates and $\mathrm{Ti}$ distribution coefficients.

Our aim in using this diagram is to relate the primitive boninite compositions from Leg 125 (plotted as a single group) to their average mantle parent. To do this, we have plotted some primitive MORB reference data (from Natland, 1989) and various melting trends. As a starting point, we have drawn the theoretical batch equilibrium melting trend of fertile MORB mantle, annotated according to percentage of melting, together with the field for experimental equilibrium melts $(10 \%-40 \%)$ of Tinaquillo lherzolite and a synthetic fertile spinel lherzolite (Jaques and Green, 1980; Fujii and Scarfe, 1985). Neither the MORB nor the Leg 125 boninite samples plot on this trend, confirming that batch melting equations do not express the true melting behavior of either MORB or boninite. By contrast, the fractional melting trend formed by instantaneous fractional melts from an FMM source passes through both the MORB and the boninite compositions. Therefore, pooling of these fractional melts (or small increments) in different ways could explain the observed scatter.

The compositions of the pooled melts lie close to the locus of instantaneous fractional melts. We represent these in Figure 16 as the integrated compositions of $10 \%$ fractional melting of mantle previously depleted by loss of $0,5,10$, and $15 \mathrm{wt} \%$ of melt. For example, the $5 \%$ mark gives the composition of the pooled melt for a total of $10 \%$ melting of mantle that has lost $5 \%$ of melt relative to an FMM composition. The Leg 125 primary melts can be viewed as the product of $10 \%$ pooled fractional melting of a fertile MORB mantle depleted by $12 \%-17 \%$ during an earlier melting event. Note that fractional 
Table 5. Examples of primitive compositions (and their norms) of a low-Ca boninite (LCB) and intermediate-Ca boninite (ICB) from Site $786 .^{\mathrm{a}}$

\begin{tabular}{|c|c|c|c|c|c|c|c|c|}
\hline $\begin{array}{l}\text { Core } \\
\text { Magma type } \\
\text { Dunite }\end{array}$ & $\begin{array}{l}62 \mathrm{R}-3 \\
\mathrm{LCB} 1\end{array}$ & $\begin{array}{l}62 \mathrm{R}-3 \\
\mathrm{LCB} 2\end{array}$ & $\begin{array}{l}62 \mathrm{R}-3 \\
\mathrm{LCB} 3\end{array}$ & $\begin{array}{l}62 \mathrm{R}-3 \\
\mathrm{LCB} 4\end{array}$ & $\begin{array}{c}44 \mathrm{R}-1 \\
\mathrm{ICB}\end{array}$ & $\begin{array}{l}36 \mathrm{R}-1 \\
\mathrm{ICB} 2\end{array}$ & ThD & $\mathrm{Hz}$ \\
\hline $\mathrm{SiO}_{2}$ & 55.95 & 55.92 & 57.47 & 62.30 & 54.17 & 55.08 & 55.99 & 59.40 \\
\hline $\mathrm{TiO}_{2}$ & 0.20 & 0.21 & 0.22 & 0.23 & 0.25 & 0.27 & 0.27 & 0.29 \\
\hline $\mathrm{Al}_{2} \mathrm{O}_{3}$ & 12.60 & 12.89 & 13.25 & 5.95 & 13.55 & 14.41 & 14.65 & 9.43 \\
\hline $\mathrm{FeO}$ & 6.62 & 6.58 & 6.76 & 7.33 & 6.95 & 6.60 & 6.71 & 7.12 \\
\hline $\mathrm{Fe}_{2} \mathrm{O}_{3}$ & 1.47 & 1.51 & 1.55 & 1.68 & 1.55 & 1.65 & 1.68 & 1.78 \\
\hline $\mathrm{MnO}$ & 0.14 & 0.14 & 0.14 & 0.16 & 0.20 & 0.20 & 0.20 & 0.22 \\
\hline $\mathrm{MgO}$ & 13.64 & 13.18 & 13.55 & 14.68 & 12.26 & 10.04 & 10.21 & 10.83 \\
\hline $\mathrm{CaO}$ & 5.52 & 5.61 & 5.77 & 6.25 & 8.23 & 8.74 & 8.88 & 9.43 \\
\hline $\mathrm{Na}_{2} \mathrm{O}$ & 3.13 & 3.21 & 1.25 & 1.36 & 2.44 & 2.59 & 1.35 & 1.46 \\
\hline $\mathrm{K}_{2} \mathrm{O}$ & 0.70 & 0.72 & 0.03 & 0.03 & 0.36 & 0.39 & 0.04 & 0.04 \\
\hline $\mathrm{P}_{2} \mathrm{O}_{5}$ & 0.03 & 0.03 & 0.01 & 0.01 & 0.03 & 0.03 & 0.01 & 0.01 \\
\hline Total & 100.00 & 100.00 & 100.00 & 99.99 & 99.99 & 100.00 & 100.00 & 100.00 \\
\hline Q & 0.0 & 4.3 & 17 & 17 & 27.1 & & & \\
\hline $\mathrm{C}$ & & & 2 & 2 & & & & \\
\hline or & 4 & 27 & 0 & 0 & 762 & & & \\
\hline$a b$ & 26 & 19 & 4.4 & 4.4 & 193 & & & \\
\hline an & 18 & 7 & 29 & 29 & 374 & & & \\
\hline di & 7.2 & 39.9 & 0 & 0 & 44.6 & & & \\
\hline hy & 41 & 0 & 45.15 & 45.15 & 27 & & & \\
\hline ol & 0 & 2 & 2.3 & 2.3 & 57 & & & \\
\hline $\mathrm{mt}$ & 2.13 & 0.4 & 0.4 & 0.4 & & & & \\
\hline il & 0.4 & 0.1 & 0.1 & 0.1 & 7.6 & & & \\
\hline ap & 0.07 & 144 & 40 & 40 & 139 & & & \\
\hline
\end{tabular}

"For each, the first column (1) is the measured analysis, recalculated to $100 \%$. The second column (2) is corrected for phenocryst content. The third column (3) is corrected for sodium and potassiumaddition. The fourth column (4) is corrected for both alkali- and aluminum-addition to the mantle source. Note the effect of the corrections on the norms and, hence, the effect on phase diagram interpretations.

melting models mean that $\mathrm{Ti}$ is highly concentrated in the first melt fractions, and diluted thereafter. As a result, the pooled melt compositions are relatively insensitive to the percentage of melting but highly sensitive to source composition. For example, modeling pooled melts from $5 \%$, rather than $10 \%$, melting only reduces the estimate of mantle depletion by about 2 percentage points. Similarly, modeling pooled melts from $15 \%$, rather than $10 \%$, melting only increases the estimate of mantle depletion by about 1 percentage point. The diagram therefore gives a good estimate of the average degree of depletion of the various boninite sources. The low-Ca boninite, having the lowest Ti content, must be derived from mantle at the upper end of the depletion range (15\%-20\%); the high-Ca boninite, having the highest $\mathrm{Ti}$ content, must be derived from the lower end of the depletion range $(10 \%-15 \%)$. By the same argument, the primitive tholeiitic melt, estimated as having about $0.4 \mathrm{wt} \%$ of $\mathrm{TiO}_{2}$, indicates only a slightly depleted source relative to FMM. Therefore, if the primitive lavas are derived from mantle with the compositional zonation of sub-oceanic lithosphere, the low-Ca boninite must be dominated by the pooling of melt fractions from the uppermost part of the lithosphere and the tholeiite by the pooling of melt fractions from the lowermost part. This concept is examined further in subsequent sections.

\section{Evidence for an Absence of Pre-subduction Mantle Metasomatism}

A second question is whether these depleted mantle sources underwent any re-enrichment by asthenospheric melts before subduction. Re-enrichment has been invoked by a number of authors (e.g., Hickey-Vargas and Reagan, 1987; Beccaluva and Serri, 1988) who suggest that silicate partial melts from an ocean island basalt (OIB) source may be responsible. Several lines of geochemical evidence suggest that this was not the case for the Leg 125 boninites. First, we have already noted that the boninite samples have isotopic compositions that plot on mixing trends between a depleted and an enriched end-member (Fig. 11). These mixing trends also can be identified in isotope and trace element diagrams (Pearce et al., this volume) and trace element ratio diagrams (Murton et al., this volume) and enable the composition of the enriched component to be estimated. We reproduce a subset of the most important diagrams in Figure 17.

$\mathrm{The} \mathrm{Ti} / \mathrm{Zr}$ ratio is one of the most diagnostic in identifying endmember compositions. In Figure 17A, we plot this ratio against $\mathrm{Th} / \mathrm{Zr}$, a ratio with one of greatest dispersions in the Leg 125 lavas. This diagram displays a progressive decrease in $\mathrm{Ti} / \mathrm{Zr}$ ratio from values as low as about 80 in the tholeiites from Site 782 through intermediate values in the boninite clasts from Hole 786A and the late dikes to values as low as 20 in the low-Ca and intermediate-Ca boninite from Site $786 \mathrm{~B}$. This order is comparable to that observed in other isotope and trace element diagrams (e.g., Fig. 11D) and, as a result, we interpret it in terms of two-component mixing. Note that, by using ratios, we reduce the effects of alteration and crystal cumulation. On the plot of $\mathrm{Ti} / \mathrm{Zr}$ against $\varepsilon N d$ (Fig. 17B), the mixing trend can be defined more precisely as involving one end-member close to Pacific MORB mantle (PMM) and the other with low $\mathrm{ENd}$ and low $\mathrm{Ti} / \mathrm{Zr}$ ratio. Pearce et al. (this volume) term the PMM component "A," and the component with low $\mathrm{Ti} / \mathrm{Zr}$ ratio "B." Figure $17 \mathrm{~A}$ shows that neither Pacific hot spots (represented by Hawaii) or island arcs (represented by the Mariana arc) contain samples with such low $\mathrm{Ti} / \mathrm{Zr}$ ratios. Thus, although component B cannot be identified unequivocally on these diagrams, it is apparent that it is not the same asthenospheric or subduction component that contributes to most intraplate and volcanic arc variability.

$\mathrm{The} \mathrm{Nb} / \mathrm{Zr}$ also is particularly diagnostic. $\mathrm{Nb}$ is more incompatible than $\mathrm{Zr}$ with respect to garnet and spinel lherzolite so that high $\mathrm{Nb} / \mathrm{Zr}$ ratios are characteristic of the small-volume asthenospheric melts associated with mantle metasomatism. Moreover, $\mathrm{Nb}$ has low concentrations in other, subduction-derived mantle components. Figure $17 \mathrm{C}$ is a plot of $\mathrm{Nb} / \mathrm{Zr}$ ratios against $\mathrm{Th} / \mathrm{Zr}$ ratios in the Leg 125 samples. It is apparent that ocean island basalts, represented by Hawaii, exhibit a marked 


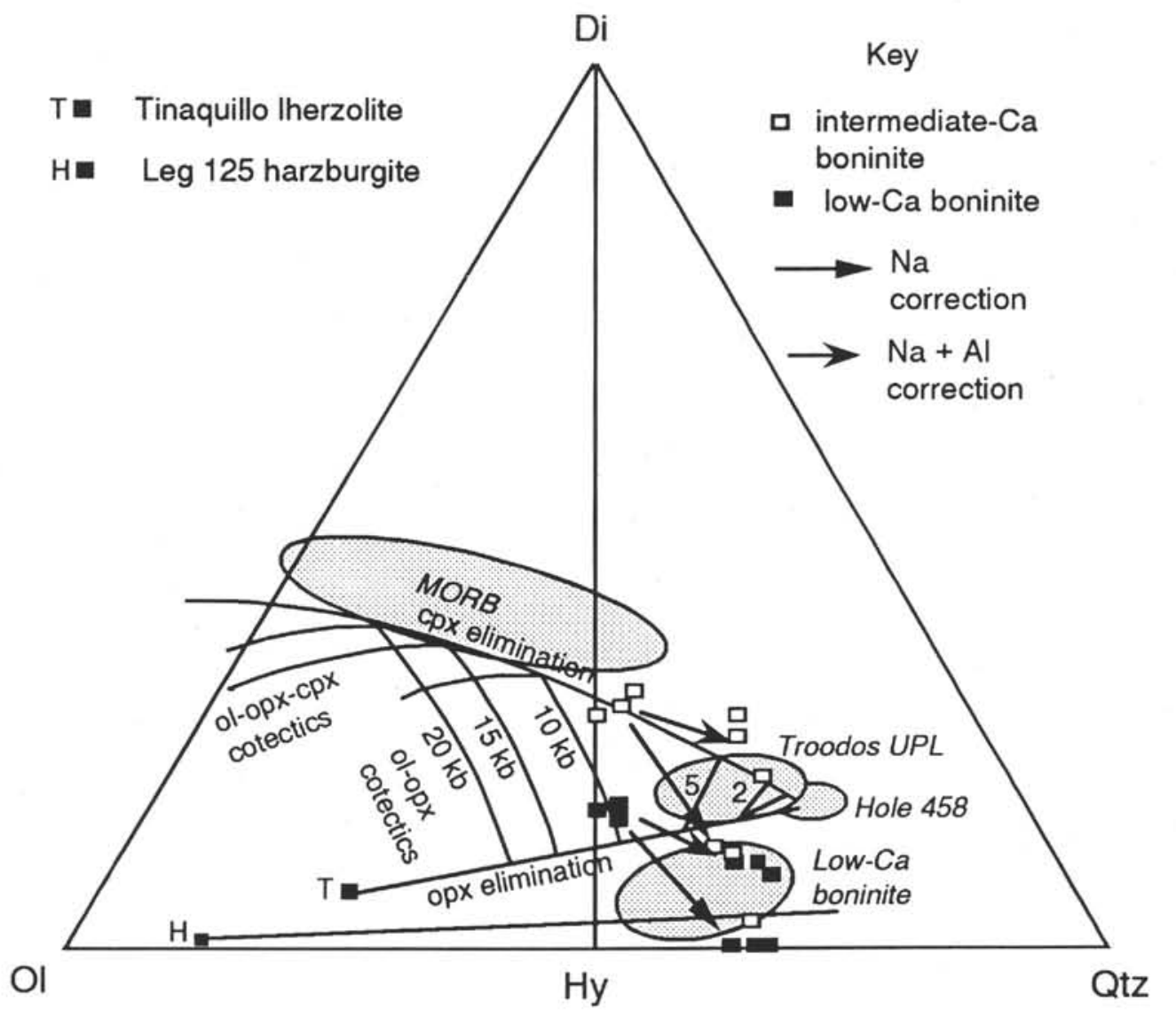

Figure 15. Estimated primary boninite compositions from Leg 125 plotted as a plagioclase projection onto the Di-Ol-Qz face of the normative basalt tetrahedron (from Green, 1970). Cotectic lines for a range of pressures are shown (Falloon et al., 1988) together with some representative boninite compositions (Crawford et al., 1989). The loci of points of pyroxene elimination from the Tinaquillo lherzolite $(\mathrm{T})$ are also shown. Boninite data for each group are shown as phenocryst-free and are linked by arrows to their $\mathrm{Na}$-corrected and $\mathrm{Na}+\mathrm{Al}$-corrected equivalents.

increase in both $\mathrm{Nb} / \mathrm{Zr}$ and $\mathrm{Th} / \mathrm{Zr}$ ratios relative to MORB. By contrast, the Leg 125 samples show a marked increase only in $\mathrm{Th} / \mathrm{Zr}$ ratios. The evidence thus suggests that there was no OIB component in the boninite source. The equivalent isotope plot (Fig. 17D) illustrates an additional point. The Pacific MORB mantle component (A) has the isotope composition of MORB but a much lower $\mathrm{Nb} / \mathrm{Zr}$ ratio. Such low ratios may be explained by a previous episode of melt extraction in which the more incompatible element, $\mathrm{Nb}$, is preferentially depleted. Therefore, the $\mathrm{Nb} / \mathrm{Zr}$ ratios provide further support for derivation of the boninite from depleted rather than fertile MORB mantle, i.e., from at least two stages of melting.

The isotope plots in Figure 11 indicate that $\mathrm{Sr}$ behaved differently from $\mathrm{Pb}$ and $\mathrm{Nd}$. The plots of $\mathrm{Sr} / \mathrm{Zr}$ against $\mathrm{Th} / \mathrm{Zr}$ and dSr (Fig. 18) illustrate this observation. Figure $18 \mathrm{~A}$ shows that the $\mathrm{Sr} / \mathrm{Zr}$ ratios vary little between most boninite groups, although the low-Ca boninite does have lower ratios. The tholeiites from Site 782 also have low $\mathrm{Sr} / \mathrm{Zr}$ ratios, although these have experienced some plagioclase crystallization. Figure 18B indicates that the lavas from Leg 125 fall along a possible mixing line but not between components $\mathrm{A}$ and $\mathrm{B}$ as defined on the basis of other elements. Thus, it is necessary also to invoke the enrichment of the depleted mantle (A) in a Sr-rich component (C). The mixing trend in Figure 18B further indicates that component $\mathrm{C}$ may have enriched the mantle before component B. Because component $\mathrm{C}$ contains only the highly mobile alkali and alkali earth elements, its probable origin is as aqueous fluids derived from a subduction zone. If the mantle is enriched in component $\mathrm{C}$ before component $\mathrm{B}$, both components must also post-date subduction. We then can infer from the mixing lines that the pre-subduction mantle (A) had the composition of depleted MORB mantle (sub-oceanic lithosphere) unenriched by asthenospheric fluids.

A final piece of evidence that component $\mathrm{B}$ is related to the subduction event and is not a pre-subduction characteristic of the mantle comes from the trace element geochemistry of the peridotites and their constituent pyroxenes (Parkinson et al., this volume). The whole-rock trace element patterns (Fig. 10) in the peridotites indicate that the enrichment characteristics strongly resemble those of the isotopic component $\mathrm{B}$, with low $\mathrm{Ti} / \mathrm{Zr}$ and $\mathrm{Sm} / \mathrm{Zr}$ ratios. The clinopyroxene crystals owe their composition to two processes: (1) the pre-subduction melting event, which depletes the mantle and, hence, the clinopyroxene in both $\mathrm{Ti}$ and $\mathrm{Zr}$; and (2) the subsequent enrichment in $\mathrm{Zr}, \mathrm{Sr}$ and light REEs relative to $\mathrm{Ti}$ and the heavy REEs. The abyssal peridotite compositions define the mantle depletion trend (Johnson et al., 1989). If $\mathrm{Ti}$ is plotted against another unenriched element such as Dy, the Leg 125 peridotites plot on an extension of this abyssal peridotite trend toward more depleted compositions (Fig. 19A). According to the modeling in Figure 16, these Ti levels correspond to about $25 \%$ of fractional melting. By contrast, when $\mathrm{Zr}$ (and the other elements in component B) are plotted against $\mathrm{Ti}$, the Leg 125 samples are displaced to more $\mathrm{Zr}$-rich compositions (Fig. 19B). Parkinson et al. (this volume) argue that the magnitude of $\mathrm{Zr}$ enrichment indicates that this enrichment occurred during the melting event and continued in the subsolidus state after melting had finished. 


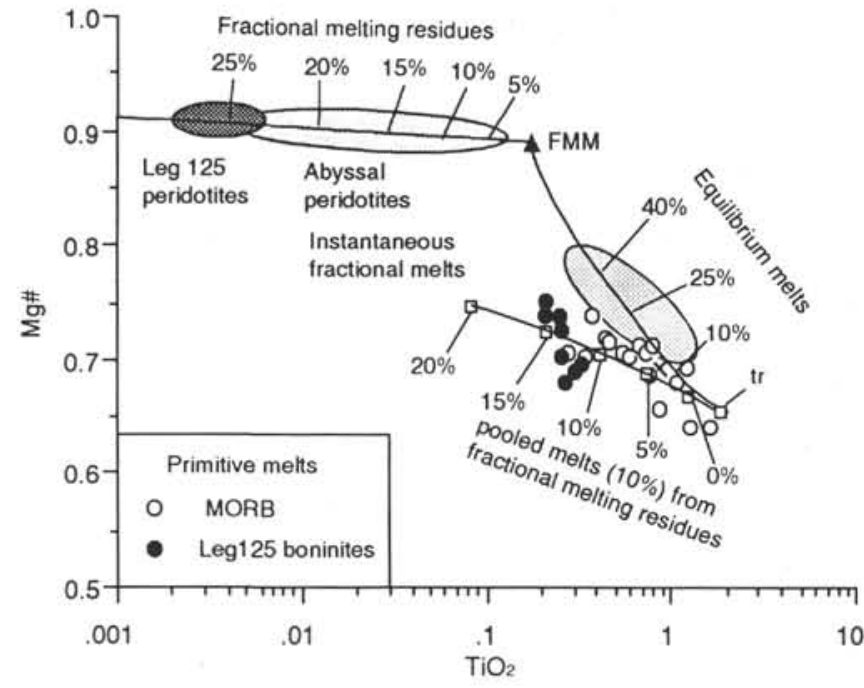

Figure 16. $\mathrm{Mg \# -TiO}$ diagram used as an indicator of the extent of source depletion of the primitive Leg 125 boninite. See text for details.

An important part of this argument is that the harzburgite has a much greater degree of enrichment than the mantle source of any of the boninite groups.

In summary, therefore, the mantle before subduction probably comprised variably depleted MORB mantle unenriched by asthenospheric fluids. All lines of evidence indicate that any enrichment of this lithosphere is related in some way to the subsequent subduction event.

\section{CONSTRAINTS ON BONINITE GENESIS 2: NATURE OF THE SUBDUCTION COMPONENT}

\section{Water Content of the Mantle Source}

Newman and van der Laan (this volume) measured water contents of about 1.4 to $1.7 \mathrm{wt} \%$ in intermediate-Ca bronzite-andesite glass samples from Leg 125. After correction for fractionation, this gives an estimated water content of 1.4 to $1.5 \mathrm{wt} \%$ in the primary magma. This value is comparable to the water contents of 1.6 to $1.7 \mathrm{wt} \%$ determined by Dobson and O'Neill (1987) for primitive low-Ca boninite magmas from Chichi-jima. For a degree of partial melting, $\mathrm{F}$, the wt. proportion of water in the mantle would then have been $1.5 \times \mathrm{F}$, assuming that water is totally incompatible during melting (i.e., that there are no residual hydrous phases) and is retained by the erupted magma before quenching. The likely degree of partial melting of $10 \% \pm 5 \%$ gives a water content of $0.15 \% \pm 0.075 \mathrm{wt} \%$. This value compares with $0.01 \mathrm{wt} \%$ to $0.04 \mathrm{wt} \%$ in fertile MORB mantle (FMM), $0.02 \mathrm{wt} \%$ to $0.22 \mathrm{wt} \%$ in back-arc basin mantle, and values up to $0.22 \mathrm{wt} \%$ and perhaps as much as $0.5 \mathrm{wt} \%$ for the sources of island arc tholeiites (Newman and van der Laan, this volume). Given the strong evidence for at least two stages of melting and the likelihood that the first stage removed almost all the water in the original source, virtually all water in the boninitic source must have been derived from the metasomatic component or components added to the source after this first stage of melting.

\section{Major Element Enrichment}

We have shown that the source prior to subduction and remelting was depleted (residual) MORB mantle that had not experienced any re-enrichment by asthenospheric fluids and that the major element composition of the boninites cannot be explained without invoking significant modification of the major element composition of mantle source by subduction fluids. The two dominant major elements, $\mathrm{Si}$ and $\mathrm{Mg}$, are likely to be buffered by their high concentrations in mantle peridotite. However, $\mathrm{Na}, \mathrm{Al}$, and $\mathrm{Ca}$ are of sufficiently low concentration in depleted lherzolites that they may be affected by the subduction zone input. We cannot easily monitor this effect by studying the Leg 125 harzburgite because the concentrations of these elements are so low and because of the effects of subsolidus enrichment. Therefore, we adopt the approach of examining the Leg 125 boninite data on plots of the most unenriched element (Ti) against the key elements and element ratios.

Figure 20 gives the plot of $\mathrm{Na}_{2} \mathrm{O}$ against $\mathrm{TiO}_{2}$. To indicate the likely range of compositions for magmas derived from unenriched mantle, we have plotted a representative set of primitive MORB compositions from Natland (1989). These form a band of decreasing $\mathrm{Na}$ with decreasing $\mathrm{Ti}$, consistent with derivation from variably depleted mantle in ascending diapirs that undergo progressive melting. Primitive island arc basalts, including those from the Mariana arc, occupy the same band, indicating that any $\mathrm{Na}$ addition to the source of these magmas is small compared with the pre-subduction $\mathrm{Na}$ content of the source. By contrast, the primitive rocks from Site 786 plot off the lowest end of the MORB trend toward high Na values. The low-Ca boninite has both lowest $\mathrm{Ti}$ and highest $\mathrm{Na}$, the high-Ca boninite has highest $\mathrm{Na}$ and lowest $\mathrm{Ti}$, and the intermediate-Ca boninite falls between the two groups. Because alteration is significant in the Leg 125 cores, one can argue that alteration is responsible for this dispersion. However, glass composition analyses by Newman and van der Laan (this volume) and van der Laan et al. (this volume), although not primitive, plot within the same region as the altered boninite samples when corrected for fractionation. Thus we conclude that the source for Leg 125 boninites was significantly enriched in Na. A similar conclusion was reached in the study of some other boninite terranes (Crawford et al., 1989). Potassium enrichment also is apparent from the trace element patterns in Figure 10.

We use the plot of $\mathrm{CaO} / \mathrm{Al}_{2} \mathrm{O}_{3}$ against $\mathrm{TiO}_{2}$ for the primitive boninites from Leg 125 (Fig. 20B) to demonstrate the relative enrichment of $\mathrm{Ca}$ and $\mathrm{Al}$ in the boninite source. The data sources are the same as those in Figure 20A. Primitive MORB follows a trend of increasing $\mathrm{CaO} / \mathrm{Al}_{2} \mathrm{O}_{3}$ ratio with decreasing Ti. This is a logical consequence of the breakdown of aluminous spinel in the early stages of melting, which causes the first melt increments to have low ratios compared with the fertile MORB mantle ratio of about unity. The high-Ca boninite samples plot on the same trend, but we cannot be certain in the absence of glass analyses that alteration was insignificant. By contrast, the primitive low-Ca and intermediate-Ca boninite (altered rocks and fresh glasses) have significantly lower $\mathrm{CaO} / \mathrm{Al}_{2} \mathrm{O}_{3}$ ratios. In the absence of any obvious explanation related to the melting process, we interpret this observation in terms of addition of a component with high $\mathrm{Al} / \mathrm{Ca}$ ratio to the boninite mantle source.

Supporting evidence from the peridotite for enrichment by Al-bearing fluids is more equivocal. Most peridotite samples fall on an extension of the abyssal peridotite trend in the $\mathrm{Al}_{2} \mathrm{O}_{3}-\mathrm{CaO}$ diagram (Fig. 12B). However, aluminum addition may explain why the residual chrome spinel (and orthopyroxene) is more aluminous (lower Cr\#s) than we expect for the observed Fo content of the olivines (Fig. 12A).

\section{Trace Element and Isotope Constraints}

Figures 10 and 17 provide convincing evidence that the boninite mantle sources have experienced a distinctive type of trace element and isotope enrichment that is not apparent in the present-day IzuBonin or Mariana arc-trench systems. Three different approaches have been used in this volume to assess the composition of the subduction component:

(1) The MORB-normalized trace element patterns. The trace element patterns published by Murton et al. (this volume) can be broken down into a mantle component and a subduction component using the methodology of Pearce (1983) and Stern et al. (1991). A base level is first drawn to give the composition the magma would 

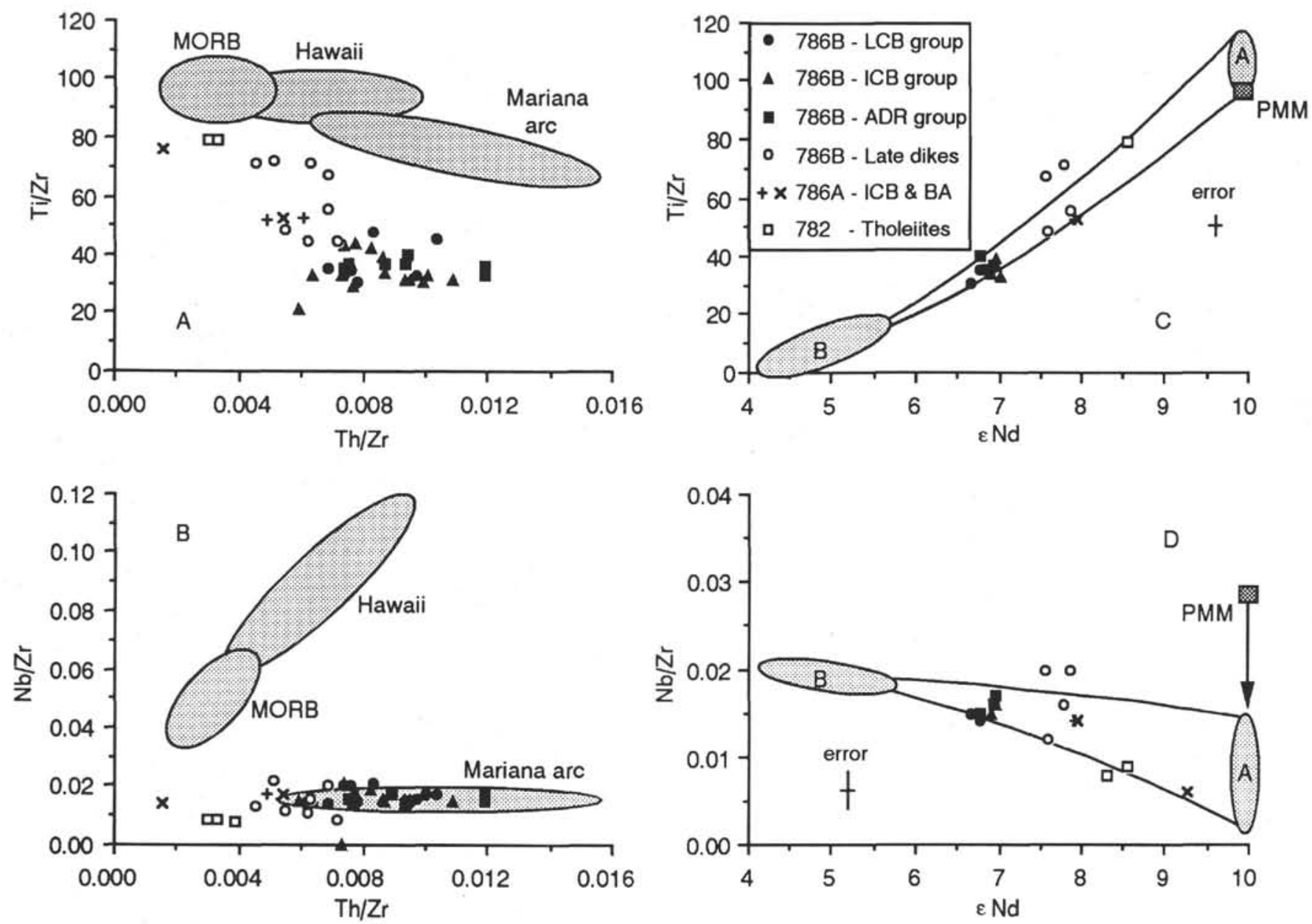

Figure 17. Diagrams showing trace element and isotope-trace element variations ( $C$ and $\mathbf{D}$ from Pearce et al., this volume) for the various volcanic rock types recovered during Leg 125. The Mariana and Hawaii fields in A and $\mathbf{B}$ show that the observed variation trends cannot be interpreted simply in terms of subduction and asthenospheric mantle enrichment components. $\mathbf{C}$ and $\mathbf{D}$ give modeled mixing lines between two end-members, $\mathbf{A}$ and $\mathbf{B}$, as discussed in the text. PMM = Pacific MORB mantle.

have produced if no subduction had taken place. We estimate this level by taking the pooled melt from $10 \%$ fractional melting of FMM depleted by an earlier episode of $10 \%$ fractional melting. The observed pattern is then subtracted from this base level to give the pattern for the enriched component. Figure $21 \mathrm{~A}$ shows the component obtained in this way, normalized to a Pacific MORB mantle for consistency with Figures $21 \mathrm{~B}$ and $21 \mathrm{C}$.

(2) The composition of the isotopic end members (Pearce et al., this volume). The mixing lines on isotope-trace element diagrams (Fig. 17) constrain the trace element ratios of the isotopic end members. Pearce et al. (this volume) argue that one end-member (A) has the isotopic composition of MORB mantle, depleted in incompatible elements by a previous episode of melting at a mid-ocean ridge. The ENd value, and hence composition, of the second end-member (B) is constrained in particular by its low $\mathrm{Ti} / \mathrm{Zr}$ ratio, which would lie below zero for $\varepsilon \mathrm{Nd}$ values less than about 4 . Trace element ratios for an $\varepsilon \mathrm{Nd}$ value of 5 taken from the various mixing curves give the enrichment pattern shown in Figure 21B. Note that the level of the pattern is based on the assumption that the Ti content of component $\mathrm{B}$ is the same as that in Pacific MORB mantle. Note also that this pattern underestimates the total enrichment of the mantle in $\mathrm{Sr}$, as component $\mathrm{C}$ (not plotted) also contains high concentrations of this element.

3. Peridotite trace element patterns. Parkinson et al. (this volume) computed the nature of the enriched component in the peridotite. The methodology used is similar to that used for interpreting the trace element patterns in the boninite samples. The theoretical pattern for the residue from $25 \%$ fractional melting of FMM is subtracted from the observed patterns. Figure $18 \mathrm{C}$ shows the resulting enrichment pattern. Note that the magnitude of the enrichment is greater than that estimated from the boninite. Parkinson et al. (this volume) explain this observation in terms of subsolidus metasomatism by this component or a component of comparable composition.

All three approaches make assumptions about the melting process, but these affect the level more than the shape of the patterns. Certain aspects of the trace element character of the enrichment component (or components) are the same: (1) high $\mathrm{Zr} / \mathrm{Sm}$ and high $\mathrm{Zr} / \mathrm{Ti}$ ratios, (2) high LIL element contents, (3) a negative $\mathrm{Nb}$ anomaly with respect to $\mathrm{La}$ and $\mathrm{Th}$ or Rb, and (4) LREE enrichment.

The isotopic systematics published by Pearce et al. (this volume) further demonstrate that, in common with many Western Pacific boninites, the lead-isotopic ratios of the three boninite types from Leg 125 lie close to the Northern Hemisphere Reference Line, the line joining MORB and ocean island basalts from northern hemisphere ridges and hot-spots (Fig. 11). This plot is in marked contrast to many recent arcs, including the Mariana arc, samples from which are displaced toward pelagic sediment. Volcanogenic sediment does, however, lie on the isotope mixing trends on $\mathrm{Pb}$ and $\mathrm{Nd}$ isotope space and may contribute to the subduction component. 

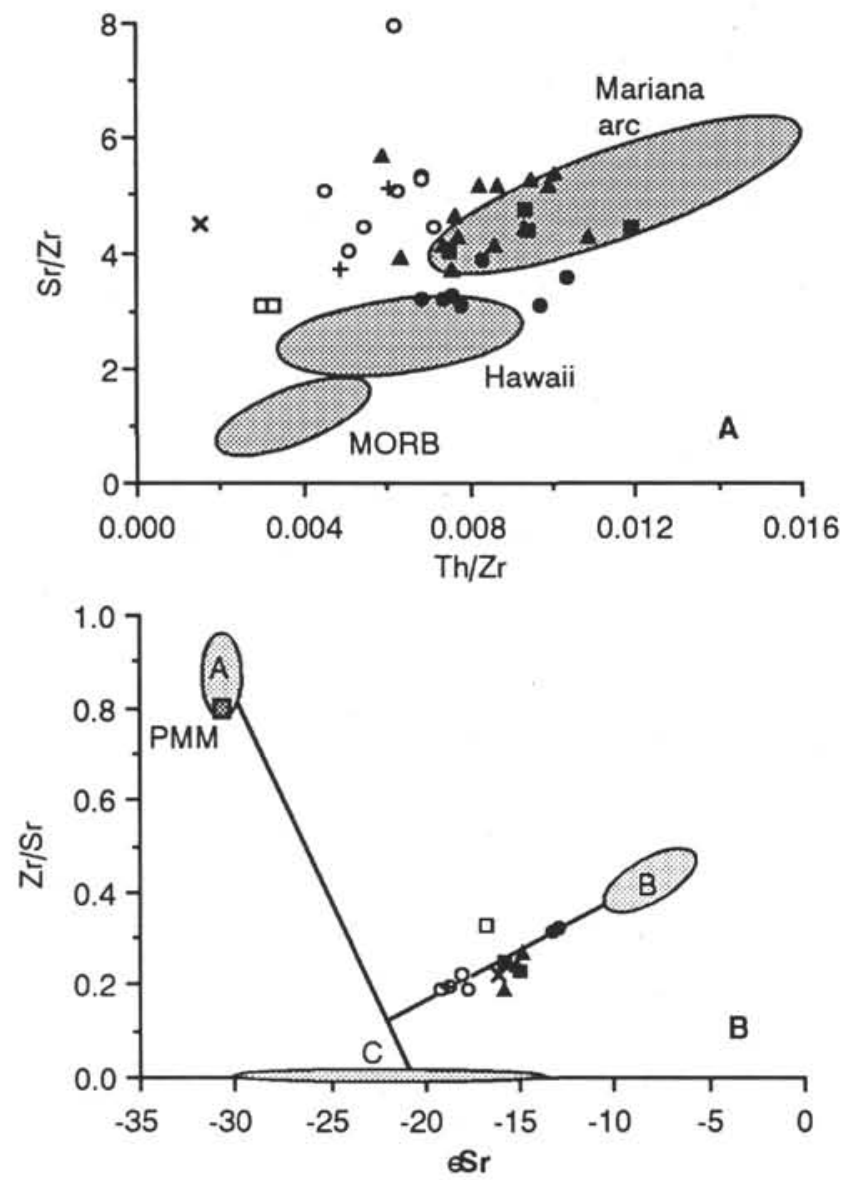

Figure 18. Diagrams (A from Murton et al., this volume and $\mathbf{B}$ from Pearce et al., this volume) to highlight the behavior of $\mathrm{Sr}$ during boninite genesis. B suggests that an additional component $(\mathrm{C})$ is required for understanding the $\mathrm{Sr}$ variations in the boninite.

\section{THE ORIGIN OF THE SUBDUCTION COMPONENT}

\section{The Role of Amphibole}

None of the major anhydrous phases are capable of significant fractionation $\mathrm{Zr} / \mathrm{Ti}$ and $\mathrm{Zr} / \mathrm{Sm}$ ratios. However, the pattern of amphibole-liquid partitioning (Fig. 22) indicates that amphibole could provide an explanation. In particular, the REE part of the pattern has a peak between Dy and Er, a mirror image of the rare earth patterns in the Leg 125 boninite samples. Moreover, the amphibole-liquid partition coefficients are high for $\mathrm{Ti}$ and low for $\mathrm{Zr}$ relative to the $\mathrm{REE}$ levels. We therefore propose that amphibole is a "key player" in boninite genesis at Site 786. There are, however, a number of ways in which amphibole might be involved.

Amphibole could be a residual phase in the melting process. However, Green's (1973) experiments demonstrate that amphibole should not be retained in the mantle at temperatures above $1200^{\circ} \mathrm{C}$ and in the presence of about $0.2 \mathrm{wt} \%$ water, the conditions prevailing during the genesis of the boninite suites from Site 786. Therefore, it is more likely that amphibole was involved in the genesis of the component or components that metasomatized the mantle source. Here we examine two options: the fractionation of trace elements by chromatographic effects during passage of small melt fractions through amphibole-bearing mantle; and the fractionation of trace elements by residual amphibole during the creation of the subduction component itself.
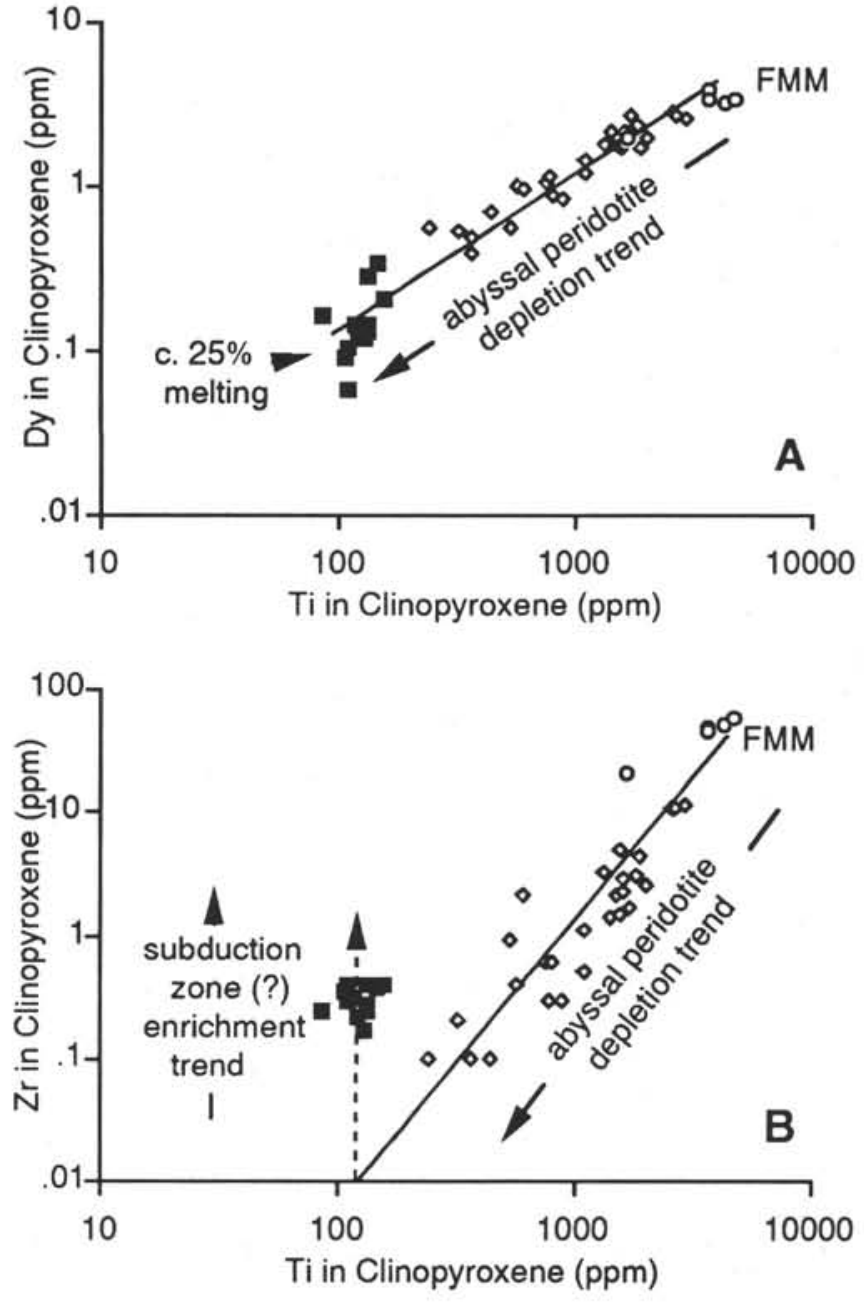

Figure 19. Dy and $\mathrm{Zr}$ plotted against $\mathrm{Ti}$ from pyroxene data from Leg 125 and abyssal peridotites (from Parkinson et al., this volume). Leg 125 data plot as an extension of the abyssal peridotite trend when Dy is plotted against $\mathrm{Ti}$ in $\mathbf{A}$, indicating that neither element is significantly enriched by subduction fluids. $\mathrm{Zr}$ is displaced from the abyssal trend in $\mathbf{B}$, indicating $\mathrm{Zr}$ enrichment. The dispersion of the data indicates that some enrichment may have postdated melting. Abyssal peridotite data (diamonds) are taken from Johnson et al. (1989).

\section{The Role of Chromatographic Fractionation}

Navon and Stolper (1987) propose that chromatography may be important in subduction zone magmatism. In the Navon and Stolper model, fractionation is achieved during two-phase flow within the sub-arc diapir. This is unlikely to be effective in boninite genesis because, as we noted, the amphibole is not a liquidus phase at the temperatures involved. Thus, $\mathrm{Ti}$ and $\mathrm{Sm}$ should not be fractionated from $\mathrm{Zr}$ and $\mathrm{Hf}$. Any fractionation must therefore take place during the metasomatic event.

In any subduction regime, a boundary layer of amphibole-bearing peridotite can form between the subduction zone itself and the zone of melting (Tatsumi, 1989; Davis and Stevenson, in press). Subduction-derived or asthenospheric fluids could pass through this "column," which would then preferentially retain the elements that are most compatible with amphibole, particularly $\mathrm{Ti}$ and the middleheavy REEs. The melt emerging from this column should then have high ratios of $\mathrm{Zr} / \mathrm{Ti}$ and $\mathrm{Zr} / \mathrm{Sm}$. Stern et al. (1991) argue that $\mathrm{Pb}$ 

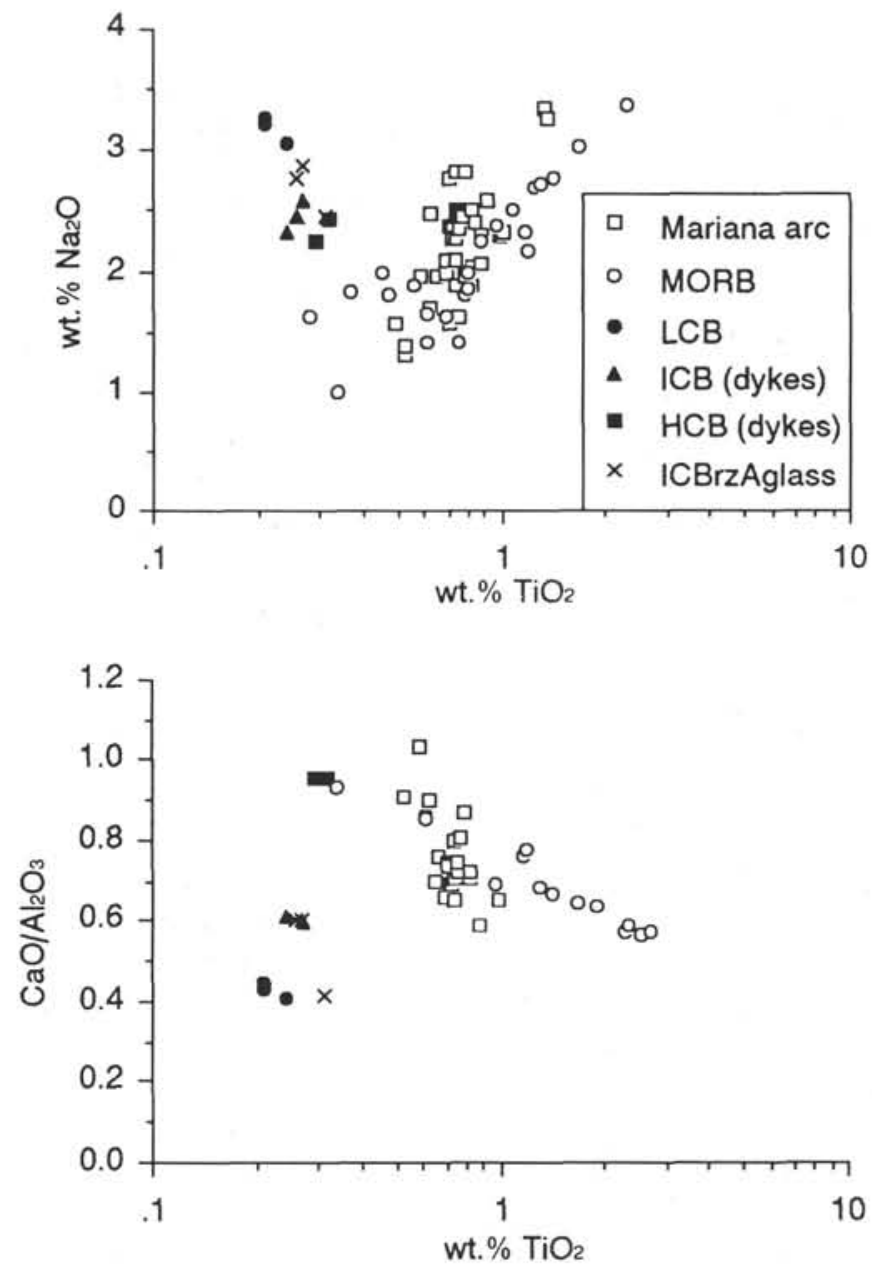

Figure 20. $\mathrm{Na}_{2} \mathrm{O}$ and $\mathrm{CaO} / \mathrm{Al}_{2} \mathrm{O}_{3}$ plotted against $\mathrm{TiO}_{2}$ for primitive boninites from Leg 125 and primitive basalts from the Mariana arc and mid-ocean ridges. The plots indicate enrichment of the boninite sources in $\mathrm{Na}$ and $\mathrm{Al}$ as well as many trace elements. $\mathrm{LCB}=$ low-Ca boninite, $\mathrm{ICB}=$ intermediate-Ca boninite, $\mathrm{HCB}=$ high-Ca boninite, ICBrzA = intermediate-Ca bronzite andesite. Leg 125 data sources are Arculus et al. (this volume) and Newman and van der Laan (this volume).

exchange in a column of this type could explain why most western Pacific boninites show no pelagic sediment signature. Given time and a static mantle, the column would rapidly be used up. If, however, this zone is itself being dragged downward along the subduction zone, it could constantly be replenished by new material. The model of Tatsumi (1989) and others requires that amphibole break down on being dragged to greater depths and that this releases water and other elements for the genesis of island arc magmatism. In this way, the high $\mathrm{Sm} / \mathrm{Zr}$ ratios in arc magmas might be the complement of the high $\mathrm{Zr} / \mathrm{Sm}$ ratios in the forearc.

Despite the elegance of this model, however, it does not explain a number of aspects of composition of Leg 125 boninites, in particular: (1) the coherence of $\mathrm{Pb}$ and Nd isotopes, (2) the enrichment of the source in aluminum as well as trace elements, and (3) the fact that boninite from Chichi-jima does have a pelagic sediment signature. Moreover, thermal modeling shows that the amphibole-bearing boundary layer between the subducted slab and the zone of melting may be very thin in the initial stages of subduction. We therefore prefer to find the explanation in the nature of the subduction component.
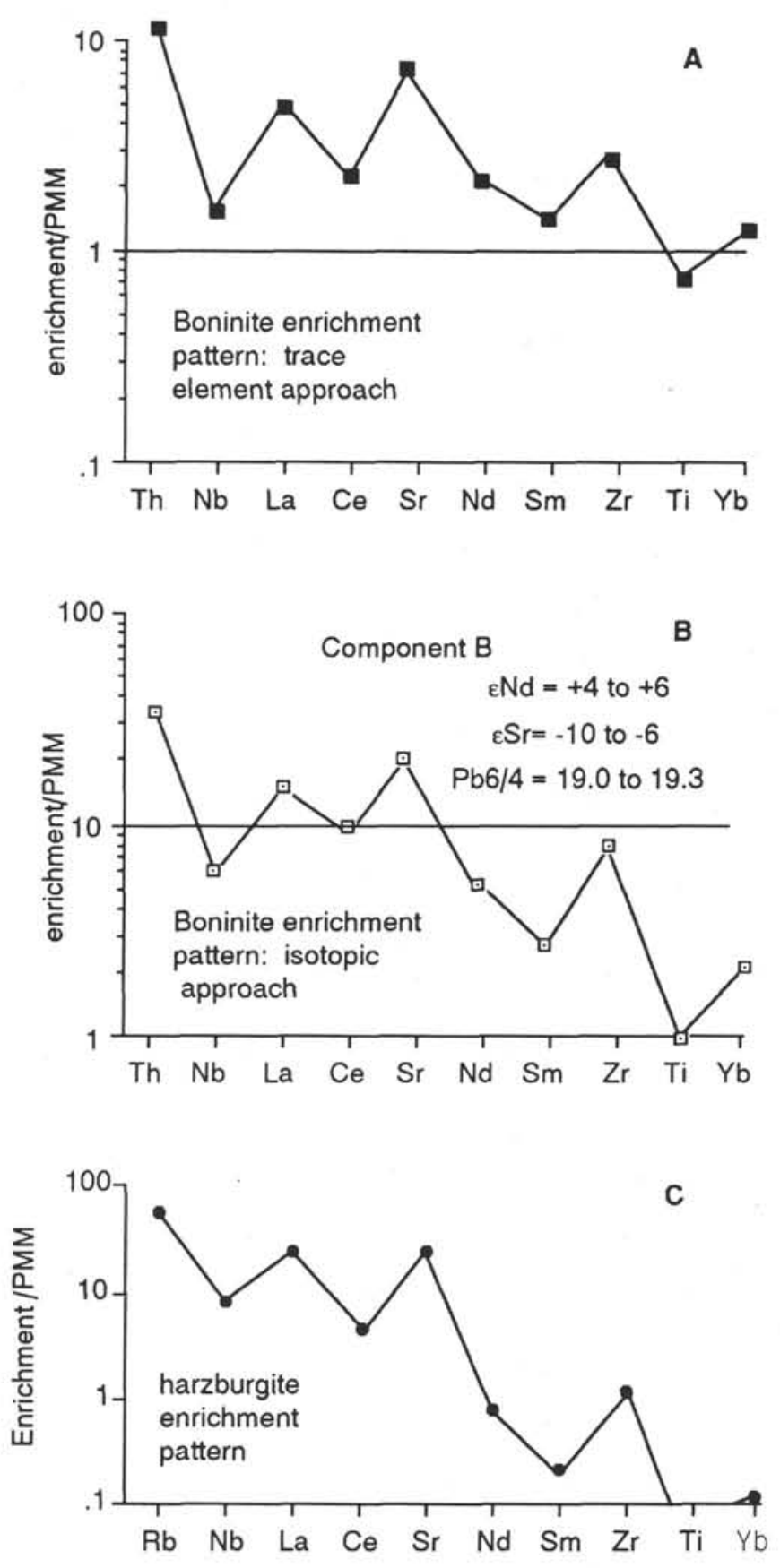

Figure 21. Trace element enrichment patterns in the subduction component in the boninite source, derived independently from trace element patterns (A) (Murton et al., this volume), isotope-trace element covariations in boninites (B) (Pearce et al., this volume), and trace element patterns in harzburgite (C) (Parkinson et al., this volume). PMM = Pacific MORB mantle.

\section{Origin by Melting of Subducted Oceanic Crust in Amphibolite Facies}

Given the lack of suitable published models on slab melting in amphibolite facies, we provide a preliminary investigation in the appendix. Our conclusion is that trondhjemitic melts with high $\mathrm{Zr} / \mathrm{Sm}$ and $\mathrm{Zr} / \mathrm{Ti}$ ratios can be generated by partial fusion of MORB in 


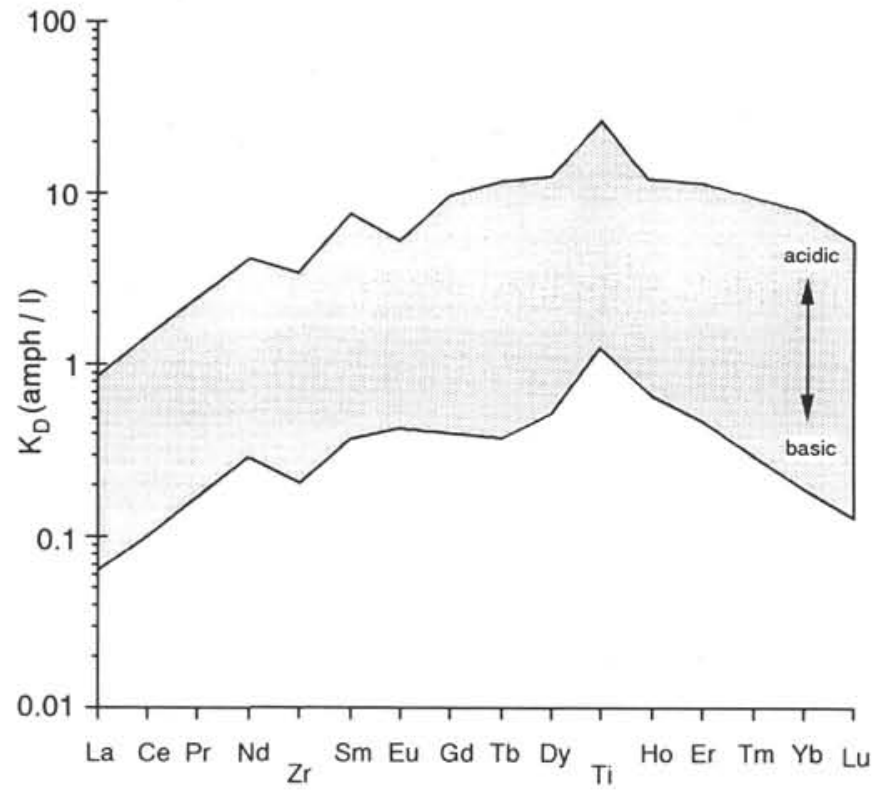

Figure 22. Amphibole-melt partition coefficients for different melt compositions. The patterns are the inverse of patterns in low-Ca and intermediate-Ca boninite, indicating possible involvement in boninite genesis.

amphibolite facies. The precise composition of these melts depends on temperature and availability of water. The greatest fractionation of these trace element ratios, but the lowest absolute abundances of the elements, is achieved at the lowest temperatures. The temperature required to initiate melting is determined by whether melting takes place under water-deficient or water-saturated conditions. To decide this, one must consider the overall fluid flux within the subduction zone. In general, the uppermost part of the slab should contain more water than is necessary to generate amphibolite. This is because the original basalt, and its metamorphic products up to greenschist facies, will contain more water than that needed to convert all mafic phases to amphibole. Because of the inverse metamorphic gradient at the top of the subducted slab, water from breakdown of greenschist facies minerals can penetrate the melt zone from below, while fluids also may flux upward along the mantle-crust interface. Even so, we do not envisage that the fluid flux will be sufficient to saturate any melt generated.

Whatever the details of the melting process, we can conclude that slab melting is capable of generating subduction components containing high $\mathrm{Ti} / \mathrm{Zr}, \mathrm{Zr} / \mathrm{Sm}$, and $\mathrm{La} / \mathrm{Sm}$ ratios. Moreover, in order for the observed subduction component to be related to slab melting, the following conditions must hold: (1) the temperature must be high enough to initiate melting in water-deficient conditions and (2) the temperature must not be sufficiently high for hornblende to melt completely (or the $\mathrm{Zr}$, Hf anomaly will not be present). Temperatures on the order of $800^{\circ} \mathrm{C}$ to $1000^{\circ} \mathrm{C}$ are likely. The principal pressure constraint is that melting must be in amphibolite facies with no residual garnet, otherwise the intermediate and heavy REEs would be fractionated (Brophy and Marsh, 1986). Therefore, the depth should lie below about $60 \mathrm{~km}$.

Note that this concept of slab melting is consistent with the thermal modeling of Peacock $(1987,1990)$. He shows that slab melting is to be expected up to about $30 \mathrm{Ma}$ after subduction of young crust and that melting at shallow depth is the theoretically predicted fate of the earliest crust to be subducted.

\section{CONSTRAINTS ON BONINITE GENESIS 3: THE PARTIAL MELTING PROCESS}

\section{Physical Constraints on the Degree of Partial Melting}

We have inferred that the boninite formed from mantle lithosphere that had already lost a melt fraction during its earlier history at a mid-ocean ridge. The question we address now is the additional melting required to generate the boninitic magmas. Any model of mantle melting has to be consistent with physical constraints. The data accumulated in this volume by van der Laan et al. and Newman and van der Laan et al. constrain the water content, depth, and temperature of the mantle, and this in turn helps to determine how much melting is possible. We estimated the water content of the mantle as $0.15 \pm 0.075$ wt $\%$ from the data of Newman and van der Laan (this volume). The pressure and temperature constraints are discussed by van der Laan et al. (this volume) and are summarized briefly below.

Our main constraints for the P-T conditions for boninite genesis in the western Pacific come from experiments on boninite glass from Chichi-jima in the Bonin Islands (van der Laan, 1987; van der Laan et al., 1989), which has a major element composition similar to that of the Leg 125 low-Ca boninite. van der Laan (1987) demonstrates that the olivine phenocrysts identified in the Leg 125 boninites could only have been a liquidus phase within a narrow window in P-T-X space (Fig. 23). Thus, van der Laan et al. (this volume) propose that the low-Ca boninite magmas segregated and started to crystallize within a narrow range of about $1260^{\circ} \mathrm{C}-1275^{\circ} \mathrm{C}$ and $0.8-1.6 \mathrm{~kb}$. High-Ca boninites are less well constrained, to within 0.5 and $3 \mathrm{~kb}$ and $1230^{\circ} \mathrm{C}-1240^{\circ} \mathrm{C}$, and intermediate-Ca boninites must lie between the ranges of the low-Ca and intermediate-Ca boninites. These temperatures correspond well to geothermometry on the boninite MD94 from Chichi-jima, which gives a temperature on the order of $1260^{\circ} \mathrm{C}$ (Dobson, 1986 ).

The significance of this temperature is emphasized by Figure 23B. The heavy lines in this figure give the solidi for mantle already depleted by loss of $10 \%$ melt from a fertile MORB mantle composition. The dry solidus is taken from McKenzie and Bickle (1988). The shape of the solidus for metasomatized mantle with a water content comparable to that in the boninite source is taken from Green's (1973) experiments on pyrolite. We assume that the solidus depression for depleted mantle is comparable to that of pyrolite, lying at about $100^{\circ} \mathrm{C}$ below that for the dry solidus at shallow depths, increasing to about $150^{\circ} \mathrm{C}$ at $10 \mathrm{~kb}$ and about $200^{\circ} \mathrm{C}$ at $15 \mathrm{~kb}$.

The solidus for the metasomatized mantle indicates that melting of the boninite source should start at or below $1200^{\circ} \mathrm{C}$, well below the estimated temperature of primary low-Ca boninite magma. Furthermore, Green (1973) reports that amphibole disappears very close to the pyrolite solidus. Prograde melting should therefore give a small quantity of water-rich melt at relatively low temperatures, but most melting will take place above the dry solidus.

Essentially, the maximum possible degree of melting is obtained by injecting the water into an ascending diapir of fertile MORB mantle that has not yet undergone melting. Davis and Bickle (in press) use the experiments of Green (1976) to show that $3 \%$ to $8 \%$ of extra melting can be achieved in this way. According to Figure 3 of Green (1973) about $8 \%$ of extra melt can be extracted from a pyrolite melt at shallow depths by addition of $0.2 \mathrm{wt} \%$ water. We do not know the extent to which fractional, rather than equilibrium, melting affects these values, but we assume here that the difference is small. The model for the compositional zonation of oceanic lithosphere of Scott and Stevenson (1989) gives $0 \%$ depletion at about $60 \mathrm{~km}$ and $20 \%$ depletion at the Moho. Thus a rough estimate of the maximum 

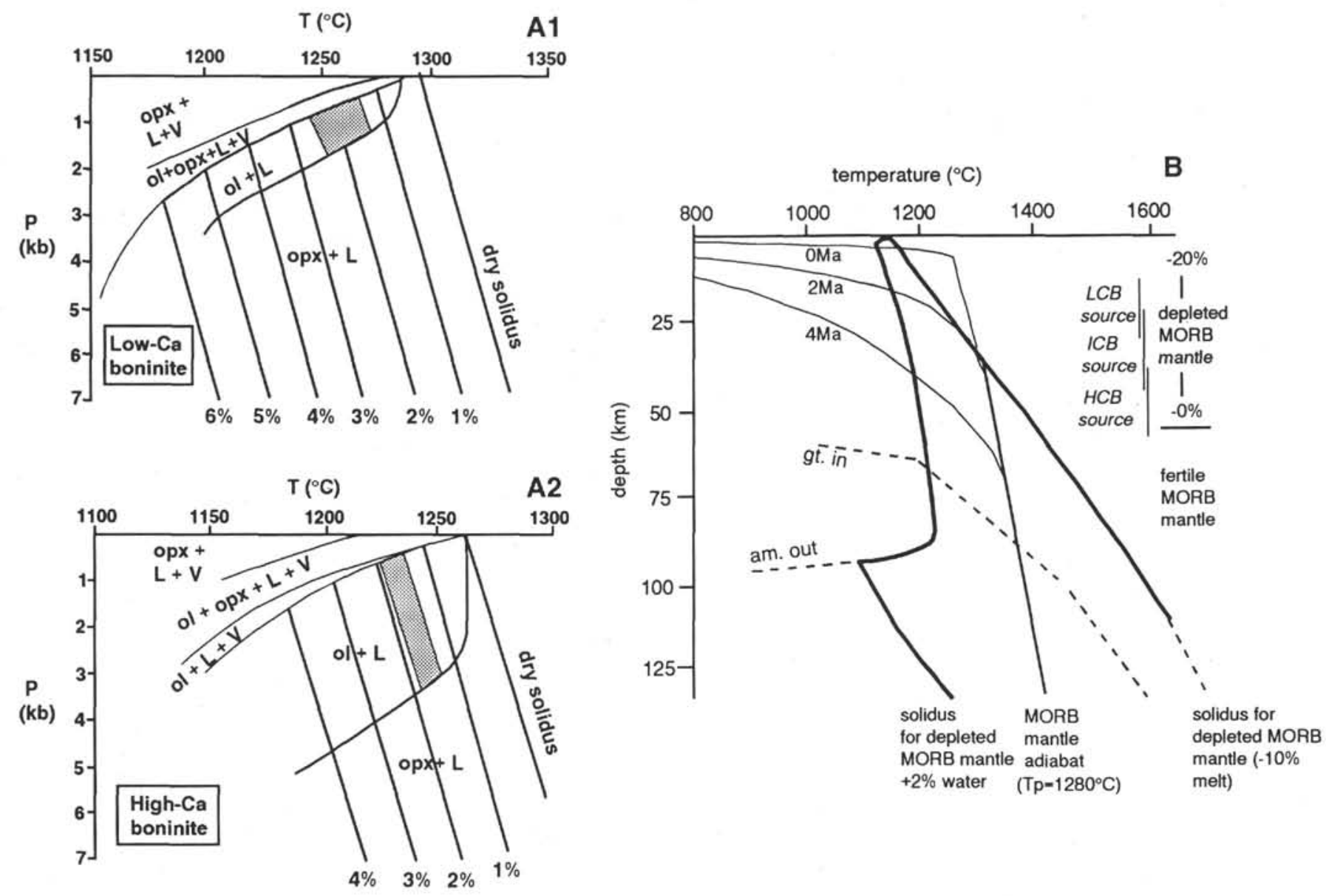

Figure 23. A. Summary of the experimental constraints on the P-T conditions of genesis (shaded) of the boninite compositions encountered at Site 786, as determined by van der Laan et al. (1989). The likely range is constrained by the water content of the boninites, as measured by Newman and van der Laan (this volume), and the early crystallization of olivine in the Leg 125 boninites (van der Laan et al., this volume). B. P-T diagram showing the probable depths of Leg 125 boninite genesis, assuming derivation from the residues of MORB genesis (the percentages give the degrees of depletion). Ages refer to the relaxation of the MORB geothem with time and emphasize the need to generate boninite within a short time of the ridge melting event. See text for full details.

extractable melt from fertile MORB mantle is $28 \%, 8 \%$ caused by addition of water and $20 \%$ by decompression during its rise to the Moho. Mantle already depleted by $10 \%$ melting (a possible average $\mathrm{HCB}$ source) can undergo a maximum of $18 \%$ melting, $8 \%$ caused by addition of water and $10 \%$ by decompression to the Moho. Mantle already depleted by $15 \%$ melting (a possible average LCB source) can undergo a maximum of about $13 \%$ melting, $8 \%$ caused by addition of water and $5 \%$ by decompression to the Moho. The enrichment of the lithosphere in $\mathrm{Na}$ will increase these estimates by an unknown amount. Note that the estimates assume separation of melt and residue at the Moho. The average degree of melting of the pooled melt increments depends on the geometry of the melt régime and is likely to be half the values quoted above, in the range of about $5 \%$ to $10 \%$.

The second constraint is temperature loss. A rough estimate of the effect of temperature on melt generation under dry conditions is that every $10^{\circ} \mathrm{C}$ fall in temperature reduces the degree of melting by $1 \%$. Thus, loss of heat by oceanic lithosphere according to the oceanic cooling curve rapidly reduces the capacity for melt generation such that very little melt can be extracted from the uppermost mantle lithosphere after even $2 \mathrm{Ma}$. The cooling effect is, of course, even greater if the lithosphere is underlain by a subduction zone. Approximate cooling curves for 2 and $4 \mathrm{Ma}$ oceanic lithosphere are shown in Figure 23B, ignoring the subduction effect. It is apparent that, for a given source composition, the boninite eruption temperature will fall after a small time interval, the length of that interval depending on the depth of the source. Even if reheated from below by conduction from a MORB during ridge subduction or rifting, the mantle temperature cannot approach the temperature of the original MORB diapir over the wide region necessary to generate the observed volume of boninite. We therefore cannot escape the conclusion of van der Laan (1987) that boninite genesis takes place by melting of oceanic lithosphere almost immediately after that lithosphere formed. We also infer from the high temperature of boninite genesis that the degrees of melting lie close to the maximum values given above, on the order of $5 \%-10 \%$.

\section{Chemical Estimates of the Degree of Partial Melting}

The best indicator of the degree of melting in the forearc may be the peridotite rather than the boninite. Ishii et al. (this volume) use the approach of Ishiwatari (1985) to assess the total degree of partial melting undergone by the harzburgites. He uses the experimental data of Jaques and Green (1980) and Mysen and Kushiro (1977) on some of the characteristic diagrams for peridotite geochemical variations. The Tinaquillo lherzolite and Hawaiian pyrolite, considered more depleted and more fertile, respectively, than a fertile MORB mantle source, bracket the behavior of the assumed source composition. The extrapolation from the anhydrous experiments to the more hydrous second stage of melting is unlikely greatly to affect the results. Ishii 


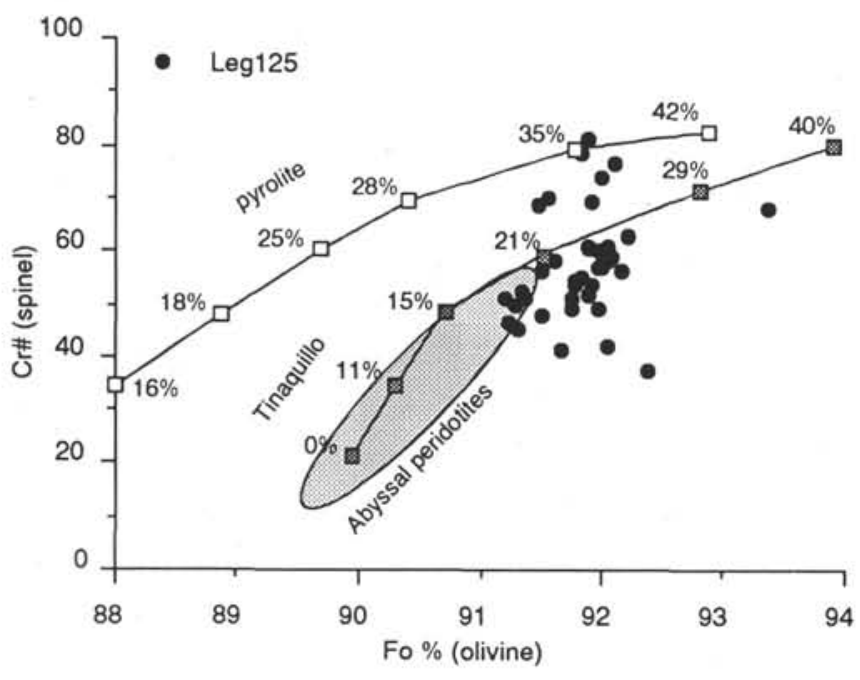

Figure 24. Cr\# in spinel against forsterite content of olivine for the Leg 125 peridotites (Ishii et al., this volume). Equilibrium melting trends for pyrolite and the Tinaquillo lherzolite (Jaques and Green, 1980) have been added (cf. Ishiwatari, 1985).

et al. (this volume) examine the depletion of whole rocks in $\mathrm{CaO}$ and $\mathrm{Al}_{2} \mathrm{O}_{3}$ during partial melting. Both are steadily depleted as the aluminous phase and clinopyroxene are progressively removed. By the time free clinopyroxene is used up at about $25 \%$ melting, the concentrations of both oxides lie well below $1 \%$. The harzburgite from Leg 125 has average values of $\mathrm{CaO}$ and $\mathrm{Al}_{2} \mathrm{O}_{3}$ of about 0.5 wt $\%$ (Fryer, Pearce, Stokking et al., 1990), consistent with their being residues from $25 \%$ to $35 \%$ equilibrium melting (cf. Fig. 12B). Note, however, that the more rapid depletion of $\mathrm{Al}$ during fractional melting may mean that these estimates are too high, although this effect may be balanced by the possible enrichment of the mantle in $\mathrm{Al}$ by subduction-derived fluids.

Because of these complications, we use instead the plot of Fo content of olivine against $\mathrm{Cr} \#$ in spinel (Fig. 24), calibrated in the same way. On this diagram, the Fo content of olivine gave degrees of melting of about $20 \%-25 \%$ using the Tinaquillo lherzolite data and $32 \%-37 \%$ using the pyrolite data. The Tinaquillo lherzolite is closest in composition to the boninite source but has already lost about $5 \%$ of melt compared with FMM (Fig. 16). Adding this 5\% to the Tinaquillo-based values gives a range of $25 \%-30 \%$ melting. The spinel Cr\#s give lower estimates but, as discussed, these may be affected by aluminum metasomatism.

We also then have to take into account the difference made by fractional rather than equilibrium melting. Figure 16 shows that a pooled fractional melt has a lower $\mathrm{Mg} \#$ than an equilibrium melt for an equivalent degree of melting. The residue for equilibrium melting will therefore have a lower $\mathrm{Mg} \#$ for a given degree of melting. The values given here are therefore maxima. Correcting for this effect we find the percentage melting falls by several percent, to an average of about $25 \%$. This result is consistent with the mineralogy. The proportion of residual clinopyroxene not formed by exsolution from orthopyroxene lies below $2 \%$, indicating a degree of melting just below $25 \%$.

If the arguments used in the last section are correct, this value of about $25 \%$ represents the residue for the maximum melt that can be extracted from a fertile MORB mantle in the presence of $0.2 \mathrm{wt} \%$ water and without any significant cooling. It does not, however, represent the residue for average degree of melting of the pooled boninite melt.

\section{A Diapiric Melting Model for Leg 125 Boninite Genesis}

Three basic types of melting have been invoked to explain the recovery of a spectrum of rock types drilled from low-Ca boninite to intermediate-Ca boninite, high-Ca boninite and tholeiites: (1) in situ melting triggered by input of fluids into mantle lithosphere (e.g., Taylor and Nesbitt, 1988; Taylor et al., in press); (2) in situ melting triggered by an input of heat into mantle lithosphere (e.g., Crawford et al., 1986); and (3) decompression melting triggered by adiabatic upwelling of depleted mantle in an extensional environment (e.g., Duncan and Green, 1987). We illustrate these options in Figure 25, together with the model of "normal" arc volcanism for comparison (Fig. 25A).

Taylor and Nesbitt (1988) use volatile-induced melting to explain spatial variations in the forearc. According to their model, the different rock types represent melting at different depths during subduction beneath zoned oceanic lithosphere (Fig. 25B). The low-Ca boninite is derived from the uppermost part of the lithosphere nearest to the trench, the high-Ca boninite and tholeiite from the deepest part of the lithosphere furthest from the trench. The second model also requires melting at different depths, but in this case the mantle is first metasomatized by a subducted slab, before heat transfer from asthenosphere in a "slab-free window" triggers melting (Fig. 25C). A comparable scenario (not shown) is heat transfer from an asthenospheric diapir during rifting. The third type of model involves adiabatic upwelling of zoned, depleted mantle (Fig. 25D), analogous to that proposed for MORB generation from asthenosphere by lithospheric extension (McKenzie and Bickle, 1988). In the third model, metasomatism takes place while the subduction angle is shallow and the rigid lithosphere is extended upon roll-back.

Whereas all three mechanisms may contribute to some extent to the genesis of Leg 125 boninite, most lines of evidence indicate that adiabatic upwelling rather than in situ melting was of greatest importance:

(1) The harzburgite represents the maximum degree of melting for boninite genesis, but not the average degree of melting, indicating that it is the most depleted residue from decompression melting and not the average residue from in situ melting (Fig. 23B).

(2) There is strong evidence for extension, especially in the dike swarm at the base of Hole 786B (Fig. 7).

(3) Experimental data point to shallow depths of melt segregation for all boninite magma types (Fig. 23A).

(4) The compositions fit pooled melts from variably depleted sources but not instantaneous melts (Fig. 16).

The type of model that fits these criteria may resemble that shown in Figure 25D. Unlike the MORB diapir of McKenzie and Bickle (1988), the boninite diapir is zoned before melting. The part of the depleted mantle that is still able to advect melts on decompression. The uppermost part generates least melt from the most depleted lithosphere, and the lowermost part generates most melt from the least depleted lithosphere. In a single diapir, the first melt comprises pooled fractions from the most depleted mantle (low-Ca boninite), and the later melts comprise pooled fractions from the least depleted mantle (tholeiite). The upwelling process may be episodic so that the pooled melts are polymodal rather than of continuous composition. Note that the precise details of such a model depend on several factors, particularly the nature of the oceanic lithosphere involved and whether convection in the mantle wedge can disturb the simple zonation depicted in Figure 25D. Moreover, we do not know whether the subduction-derived fluids invade the mantle as extension proceeds or whether the lithosphere composition is modified by incipient vola- 

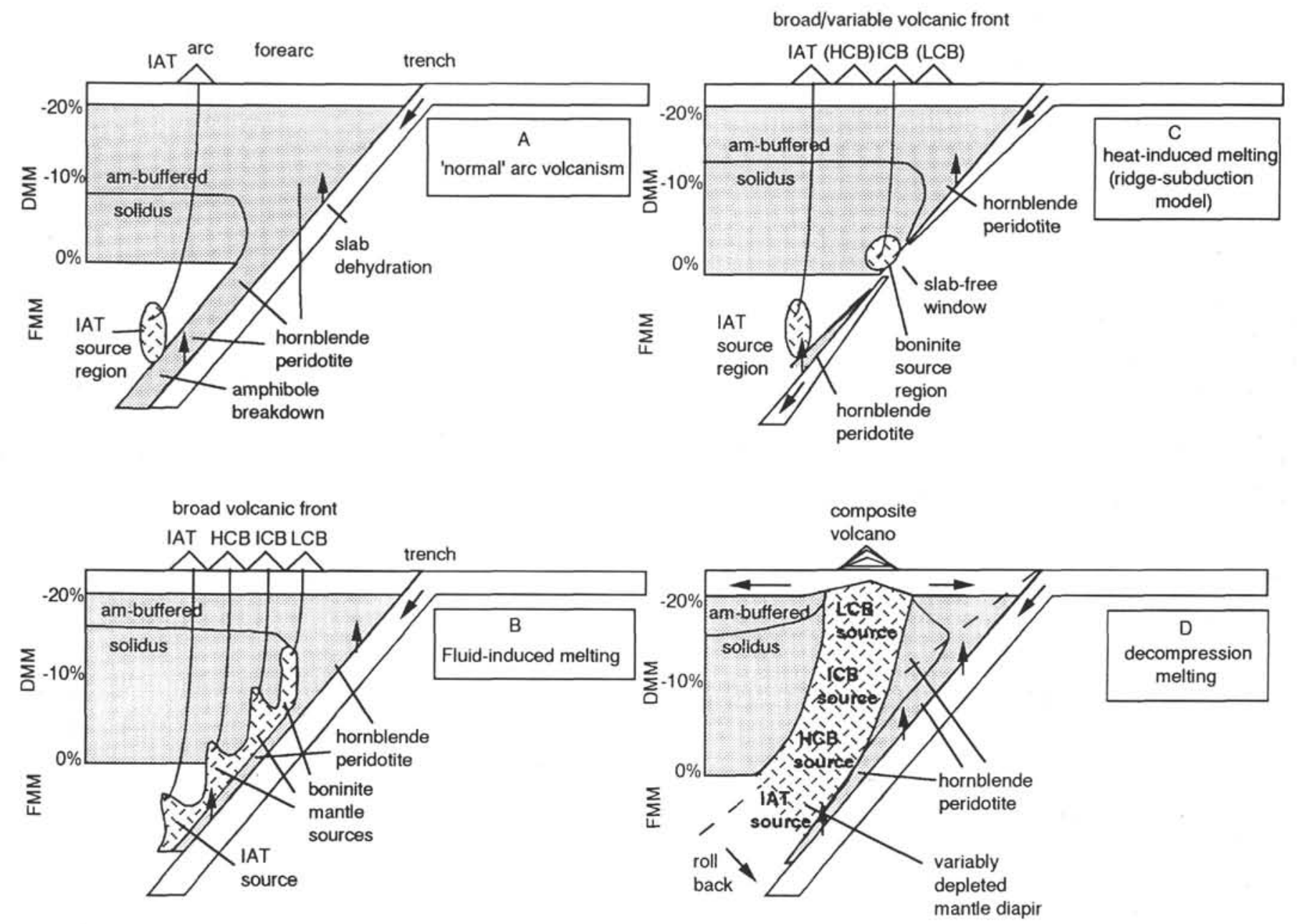

Figure 25. End-member models for boninite genesis by fluid-induced $(\mathbf{B})$, heat-induced $(\mathbf{C})$, and decompression-induced $(\mathbf{D})$ melting of the shallow mantle wedge. A shows "normal" arc genesis for comparison.

tile-induced melting before extension. These aspects are the subject of continuing investigations.

\section{THERMAL CONSTRAINTS ON MODELS OF THE GENESIS OF LEG 125 BONINITE AT THE INITIATION OF SUBDUCTION}

Our aim is now to examine the extent to which the proposed types of tectonic models for genesis of Leg 125 boninite (listed in the Introduction) are consistent with the petrogenetic constraints inferred above. Many thermal models of subduction based on the $2 \mathrm{D}$ finite difference method exist in the literature. None precisely model the initiation of subduction at a ridge-transform intersection. However, Hsui and Toksöz (1979) modeled the initiation of subduction in cold oceanic lithosphere with and without viscous shear heating. In their model, slab melting cannot initiate at shallower depths than the amphibolite-eclogite transition, and thus this is not a viable model of the genesis of Leg 125 boninite. To explain shallow melting of the subducted slab, one must consider subduction beneath hot lithosphere, subduction of hot lithosphere, or advection of hot asthenosphere into the forearc (e.g., Peacock, 1990).

In Figure 26, we present a thermal model for the transition from transform to subduction tectonics. We take two sections across the transform zone just after subduction has started, one where ridge subduction is taking place, the other where subduction beneath a ridge is taking place. The location of these sections is shown in Figure 6. The basic method of modeling is that of Peacock (1990) for a slab dip angle of $45^{\circ}$. We do not aim at this stage to examine the full complexities of the process. Thus, no account is taken of shear heating along the subduction interface, the heats of dehydration and fusion, or advection within the mantle wedge.

\section{Subduction Beneath Hot Oceanic Lithosphere of an Active Ridge}

Figure 26A shows the thermal structure that might be expected after subduction of oceanic lithosphere beneath an active ridge crest or very young oceanic lithosphere according to the model of Casey and Dewey (1984). In this model, fluids and/or melt from subducted lithosphere interact with the still-hot suboceanic lithosphere of the overlying mantle wedge to trigger melting. As illustrated in the P-T section in Figure 23B, melting can take place if the overlying lithosphere is young enough that it still exceeds the temperature of the water-undersaturated mantle solidus. An end-member of this process is subduction beneath an active ridge, in which the melt residue is enriched from the subducted slab and remelted immediately after becoming the residue from melting at the ridge axis. Figure $26 \mathrm{~A}$ shows that this setting provides sufficient heat to explain both slab melting in amphibolite facies and melting of residual MORB mantle at depths below $50 \mathrm{~km}$. Moreover, a large volume of mantle in the 

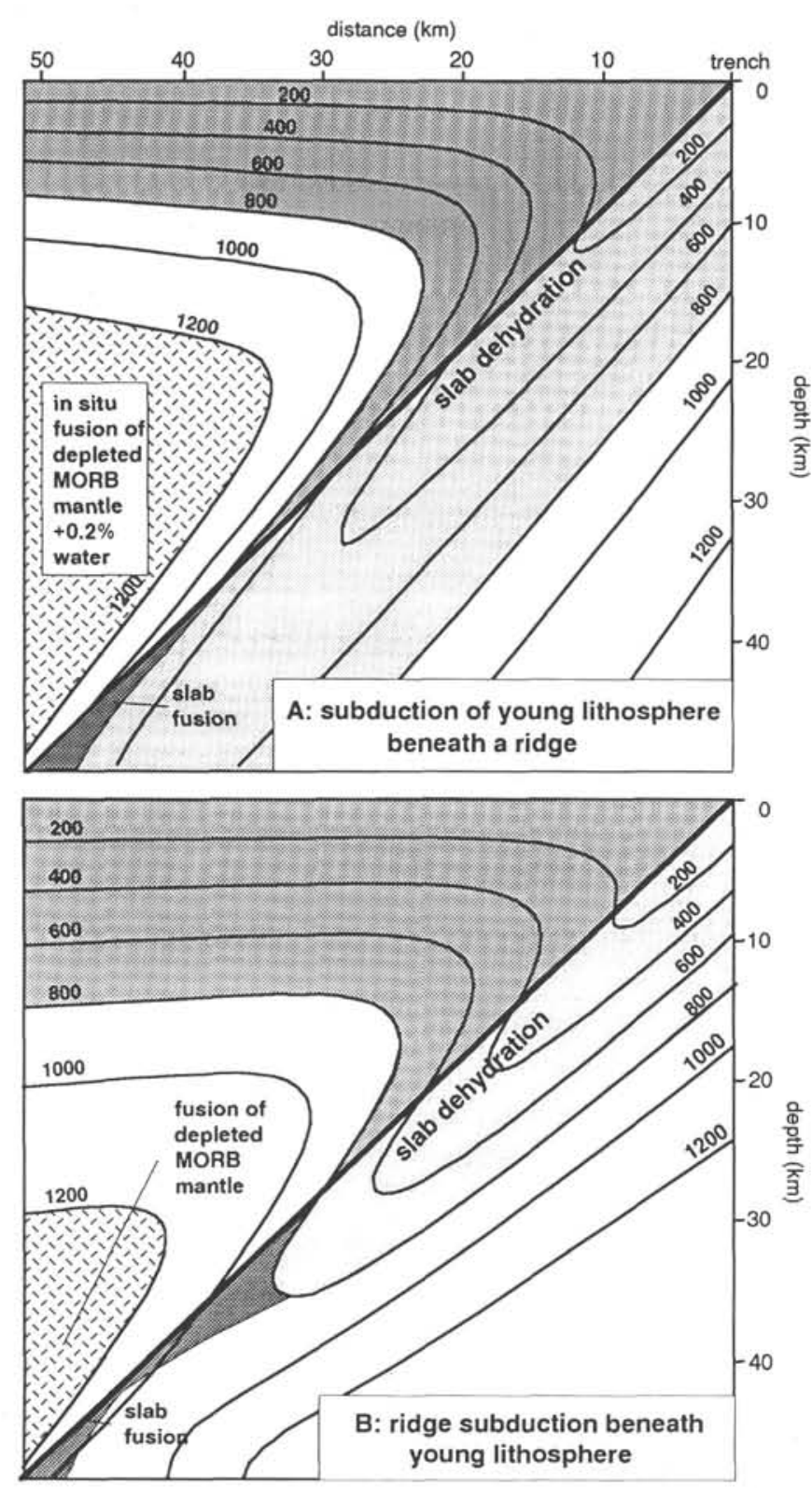

Figure 26. Finite-difference thermal models for the genesis of boninites by subduction beneath a ridge and subduction of a ridge. Modeling simulates a ridge-transform system that has been placed in compression, along lines $\mathrm{A}$ and $\mathrm{B}$ in Figure 6D. The methodology is broadly similar to that described by Peacock (1990). The subduction rate is $5 \mathrm{~mm} / \mathrm{Ma}$, and spreading half-rates are $1 \mathrm{~mm} / \mathrm{Ma}$. The model spans a time period of $2 \mathrm{Ma}$. Shaded parts of the subducted lithosphere and overriding plates below $800^{\circ} \mathrm{C}$ approximate to mechanical lithosphere.

mantle wedge is potentially fusible under these conditions (fluidinduced melting). We envisage that diapiric upwelling is induced by the combination of the gravitational instability of this partially molten mantle, the weakness and thinness of the overlying mechanical boundary layer, and the extension associated with "trench pull." As noted earlier, this setting also provides the simplest explanation for the high temperatures of boninite genesis (van der Laan, 1987).

There are a number of possible extant examples of this process where backarc spreading axes intersect a subduction zone or a zone of transpression, such as the southern part of the Mariana Trough, the northern Lau Basin, or the northern Scotia Sea (Casey and Dewey, 1984). Boninite is erupted in these settings, though high-Ca boninite is the dominant magma type. In these areas, the subducted lithosphere is significantly older than that modeled in Figure 26. This must cool the mantle wedge and perhaps inhibit shallow melting. In the Mariana region, we argue, the maximum temperatures in both the mantle wedge and the subducted slab are reached at the initiation of subduction, after which the subduction process cools the overlying lithosphere.

\section{Ridge Subduction and Subduction of Hot Lithosphere}

We present a model for the ridge subduction aspect of the Western Pacific plate reorganization in Figure 26B. De Long et al. (1979) were among the first to examine the thermal and petrogenetic consequences of ridge subduction, beneath thermally mature (rather than immature as here) oceanic lithosphere. They conclude that this process may be a cause of "anomalous near-trench magmatism." In their model, dehydration of subducted lithosphere metasomatizes the overlying mantle, which then is melted as the ridge is subducted and hot asthenosphere rises close to the base of the mantle wedge. A time lag exists between ridge subduction and the maximum temperature reached in the mantle wedge because of the slow rate of conductive heat transfer.

For Leg 125 boninite, the difficulty with the model as published by DeLong et al. (1979) is that the temperature of the mantle wedge is too low to generate melt at shallow depths, because the wedge is cooled by subduction of the slab before the subduction of the ridge. This is true even in the modeled case of subduction beneath young (10-20 Ma) lithosphere. Contact melting of metasomatized lithosphere by heat from the asthenosphere in the slab-free window can generate a small amount of melt at the amphibole-controlled solidus some $100^{\circ} \mathrm{C}$ or more below the likely boninite liquidus temperature. The latent heat of melting and the progressive removal of the heat source as subduction proceeds may, however, inhibit the generation of much magma from highly residual mantle. Thus, whereas boninites may be generated by ridge subduction, they are only likely to be high-Ca boninite and, if not, may lie considerably below the melting temperature required for Leg 125 boninites. For example, the highmagnesium andesite from New Georgia emplaced above the subducting spreading center of the Woodlark Basin gives temperatures of $1100^{\circ} \mathrm{C}$ (groundmass quenching) and $1140^{\circ} \mathrm{C}$ (pyroxene phenocryst geothermometry) (Johnson et al., 1987).

Therefore, we tentatively conclude that ridge subduction can aid boninite genesis but is likely to have been instrumental in the genesis of Leg 125 boninites only if ridge subduction had taken place beneath young, hot lithosphere and if ridge subduction were not pre-dated by subduction of a lengthy slab of old lithosphere.

A further relevant consequence of ridge subduction is the greatly enhanced capacity for melting of the subducted slab. DeLong et al. (1979) consider this possibility, which was investigated more extensively by Defant and Drummond (1990) and Drummond and Defant (in press) (see appendix). They argue that the most fertile zone of melting lies at 23 to $26 \mathrm{~kb}$ and $770^{\circ} \mathrm{C}$ to $775^{\circ} \mathrm{C}$, where dehydration and wet partial melting of the slab can occur together. They also note that dacitic arc magmas with the right composition to have been derived directly from slab melting are associated with subduction of young $(<30 \mathrm{Ma})$ and hence hot lithosphere. All the acid rocks recovered during Leg 125 are derived by fractionation of more basic parents and not by slab fusion. Thus, although acid magmas are likely to be derived from the subducted slab, we require that these magmas hybridize with the overlying mantle rather than erupt directly at the surface. It is then the hybridized mantle that melts to give parental boninite magma. This difference in behavior may be attributed to the temperature of the mantle wedge. Acidic magmas derived from the slab may originate at greater depths and erupt to the surface if the mantle wedge is cool (as in Central America and Alaska), but they originate at shallow depths and cause mantle melting when the wedge is hot.

Thus, we conclude that the most effective setting for generating the low-Ca and intermediate-Ca boninites is the activation of subduction at or near an active ridge-transform intersection. In such a setting, 
subduction of young lithosphere can combine with subduction beneath young lithosphere. Such a model explains in particular (1) the absence of any obvious subducted sediment component, as the subducted lithosphere would be young and sediment cover small; (2) the melting of depleted mantle at high temperatures; and (3) the coincidence of boninite generation and the change in Pacific Plate motion.

\section{LEG 125 PETROGENESIS IN A REGIONAL CONTEXT}

Arculus et al., van der Laan et al., Murton et al., and Pearce et al. (this volume) all note significant differences in composition between the various boninite suites so far studied from the Western Pacific "proto-arc" terrane (Figs. 1 and 4). Here we summarize some of these differences in terms of a subset of the plots used earlier to investigate the genesis of Leg 125 boninites: the rare earth and trace element patterns; the $\mathrm{Pb}$ isotope plot; the $\mathrm{Ti} / \mathrm{Zr}-\varepsilon \mathrm{Nd}$ diagram; the $\mathrm{TiO}_{2}-\mathrm{Mg} \#$ diagram; and the $\mathrm{Hf} / \mathrm{Sm}-\mathrm{La} / \mathrm{Sm}$ diagram. The data (summarized in Table 6) are taken from:

1. The West Philippine Basin (Meijer, 1975)

2. Chichi-jima (Hickey and Frey, 1982; Cameron et al., 1983; Dobson and Tilton, 1989)

3. Guam (Meijer, 1976; Hickey-Vargas and Reagan, 1987)

4. Saipan (Meijer, 1983)

5. DSDP Leg 60 (Mariana forearc) (Hickey-Vargas, 1989)

6. The Mariana inner trench wall (Stern et al., 1991)

7. Zambales ophiolite (Yumul, 1990)

8. Palau (J.A.P., unpubl. data)

REE patterns (Fig. 27A) and trace element patterns (Fig. 27B) highlight the nature of mantle enrichment. Both vary widely between the Western Pacific boninite localities. Of the REE patterns, the Zambales ophiolite forms one end of the spectrum, with strongly LREE-depleted patterns indicative of an absence of any LREE-bearing subduction component. The Site 458 boninite also has LREEdepleted patterns. At the other end of the spectrum, dredge site D28 has a strongly LREE-enriched pattern. Flat to slightly U-shaped patterns are characteristic of boninite from Chichi-jima, Guam, and dredge site D50, as well as Leg 125.

Of the trace element patterns, all exhibit enrichment of the most mobile elements, $\mathrm{Sr}, \mathrm{K}, \mathrm{Rb}, \mathrm{Ba}$, and (to a lesser extent) Th relative to the high field-strength (HFS) elements. The conventional explanation of this enrichment is that it results in part from aqueous fluid fluxing from subducted oceanic lithosphere. For the Leg 125 samples, it is equivalent to component $\mathrm{C}$ of Pearce et al. (this volume). The Zambales sample contains only this component, as do some samples from Palau, not shown in this plot. Most other samples exhibit the additional enrichment in LREE and many HFS elements that gives rise to the high $\mathrm{Zr} / \mathrm{Sm}$ and $\mathrm{Zr} / \mathrm{Ti}$ ratios. For the Leg 125 samples, this is equivalent to component B of Pearce et al. (this volume), which we interpret in this paper as the product of slab fusion. Dredge site D28 exhibits the greatest enrichment in this component, DSDP Site 458 the least.

The $\mathrm{Pb}$ isotope diagram (Hickey-Vargas, 1989; Dobson and Tilton, 1989; Stern et al., 1991; Pearce et al., this volume) (Fig. 28A) highlights the magnitude of any pelagic sediment component in the mantle source. It shows that most boninite series plot on or close to the Northern Hemisphere Reference Line (NHRL). The principal exception is the Chichi-jima boninite and, possibly, the Guam Alutom series, suggesting that only the latter may have had a pelagic sediment component in their source (Dobson and Tilton, 1989). The Ti/Zr- $\varepsilon \mathrm{Nd}$ diagram (Fig. 28B) shows a similar feature. Most of the boninite suites can be explained by mixing of two components, one similar to PMM (component $\mathrm{A}$ ), the other with low $\mathrm{Ti} / \mathrm{Zr}$ ratio and $\varepsilon \mathrm{Nd}$ on the order of 5-8 (component $\mathrm{B}$ ). Chichi-jima, by contrast, displays a trend toward the low $\varepsilon \mathrm{Nd}$, pelagic sediment, component (D). These variations thus reinforce the interpretations made from the trace element patterns. Note that the aqueous subduction component, component $\mathrm{C}$, appears only in projections involving $\mathrm{Sr}$ isotopes and mobile elements.

The $\mathrm{TiO}_{2}-\mathrm{Mg} \#$ diagram (Fig. 29A) defines the variability in degree of depletion of the mantle source. In particular, Chichi-jima and dredge site 28 in the Mariana inner trench wall have low Ti contents and are best explained by derivation from the most depleted sources. Boninites from dredge site 1403 and drill site DSDP 458 have Ti contents comparable to the low-Ca and intermediate-Ca boninite from Site 786. Boninites from the Facpi group from Guam have Ti contents comparable to the high-Ca boninite from Site 786. The Acoje Block of the Zambales ophiolite has variable Ti values indicative of derivation from variably depleted sources. The Site 458 tholeiites, like the Leg 125 tholeiites, have high Ti contents indicative of derivation from sources closer to fertile MORB mantle.

The Hf/Sm-La/Sm diagram (Fig. 29B) highlights the variability in the subduction component. This diagram discriminates between two types of subduction vector. The first is directed toward both high $\mathrm{Zr} / \mathrm{Sm}$ and high $\mathrm{La} / \mathrm{Sm}$ ratios, which we model in this chapter as the product of partial fusion of oceanic crust in amphibolite facies. The second is directed toward high $\mathrm{La} / \mathrm{Sm}$ ratios and slightly lower $\mathrm{Zr} / \mathrm{Sm}$ ratios and is followed by lavas from the active Mariana arc. In keeping with detailed interpretations of the chemistry of this arc (e.g., Woodhead, 1989), we interpret this vector in terms of derivation from dehydration and partial fusion of subducted sediment.

As the trace element patterns in Figure 27 also show, the Acoje block of the Zambales ophiolite contains Eocene boninites derived from mantle containing no REE-bearing component. Boninite from Palau and Saipan and (for some samples) Guam, together with tholeiites from Site 458, form a trend in the direction of the second vector. Boninite from the Mariana trench, Site 458, Chichi-jima, and Leg 125 plot in the direction of the first vector. Surprisingly, the Chichi-jima boninite does not follow the Mariana vector, despite its lead isotope pelagic sediment signature. Mixing calculations, not carried out to date, may resolve this "anomaly."

The diagrams in Figures 27-29 emphasize the wide variability in almost all aspects of petrogenesis for the Eocene and early Oligocene boninites from the Western Pacific: degree of melting, degree of source depletion, pre-subduction mantle composition, and subduction component. The Eocene boninite samples collected during Leg 125 represent in many respects an average petrogenetic history.

At this stage in our understanding, perhaps because of the small number of localities, it is difficult to identify many systematic spatial variations in petrogenesis. Note, however, that it is the most southerly localities (Zambales and Palau) that contain no obvious (inferred) slab fusion component. The reconstruction in Figure 4 places these southern localities alongside the active spreading center in the West Philippine Basin. By contrast, Chichi-jima and the Leg 125 boninite sites are located alongside the Oki-Daito-Amami province, adjacent to Cretaceous or Paleocene lithosphere at Site 786. If this is correct, the Leg 125 boninites should, according to the discussion presented earlier, have lower temperatures and a more enriched pre-subduction mantle. As the mantle wedge will be cooler, they should also have a smaller "slab-fusion" component. The fact that none of these features are observed indicates that this model is too simplistic and that simple juxtaposition of the West Philippine Basin and the "proto-arc" may not give the complete story.

We can also recognize temporal variations. Most enigmatic is the fact that the Chichi-jima boninite is the only Eocene rock type to be displaced from the NHRL on a $\mathrm{Pb}$ isotope diagram. Advocates of an origin for Chichi-jima before plate reorganization argue that Chichijima boninite differs from Leg 125 boninite because it is older and had a different tectonic setting. As we noted in an earlier section, however, there may be other explanations. It is also apparent that the early Oligocene boninite and tholeiite series volcanic rocks lie closer to MORB in their isotope and trace element characteristics than the Eocene boninites and have compositions that suggest melting of less residual mantle and, hence, a deeper source. This circumstance could 
Table 6. Representative analyses of boninite samples from Leg 125 and other parts of the Western Pacific Eocene-Oligocene province. ${ }^{a}$

\begin{tabular}{|c|c|c|c|c|c|c|c|c|c|c|c|c|}
\hline Region & $\begin{array}{l}\text { Leg } \\
125\end{array}$ & $\begin{array}{l}\text { Leg } \\
125\end{array}$ & $\begin{array}{l}\text { Leg } \\
125\end{array}$ & $\begin{array}{l}\text { Leg } \\
125\end{array}$ & $\begin{array}{l}\text { Chichi- } \\
\text { jima }\end{array}$ & $\begin{array}{c}\text { Mariana } \\
\text { Trench }\end{array}$ & $\begin{array}{c}\text { Mariana } \\
\text { Trench }\end{array}$ & $\begin{array}{c}\text { Mariana } \\
\text { Trench }\end{array}$ & Guam & $\begin{array}{c}\text { ODP } \\
\text { Leg } 60\end{array}$ & $\begin{array}{l}\text { Palau } \\
\text { Is. }\end{array}$ & $\begin{array}{l}\text { Zambales } \\
\text { Ophiolite }\end{array}$ \\
\hline Unit & $786 \mathrm{~B}$ & $768 \mathrm{~B}$ & $786 \mathrm{~B}$ & $786 \mathrm{~B}$ & Marubewan & Site 28 & Site 50 & Site 1403 & Facpi & Site 458 & Babelthaup & Acoje \\
\hline Sample & $62 \mathrm{R}-3$ & $11 \mathrm{R}-1$ & $67 R-1$ & $40 \mathrm{R}-2$ & $\mathrm{X} 108$ & $28-1$ & 50.17 & 44 & $89-1$ & $40-1$ & Pa86-14 & $\mathrm{Z} 298$ \\
\hline Rock type & LCB & ICB & ICB & $\mathrm{HCB}$ & ICB & LCB & ICB & LCB & ICB & ICB & HCB & HCB \\
\hline $\mathrm{SiO}_{2}$ & 55.40 & 56.43 & 55.11 & 50.51 & 58.01 & 60.75 & 57.11 & 58.68 & 55.07 & 54.23 & 53.65 & 052.99 \\
\hline $\mathrm{TiO}_{2}$ & 0.21 & 0.23 & 0.26 & 0.33 & 0.14 & 0.16 & 0.18 & 0.23 & 0.49 & 0.34 & 0.47 & 0.34 \\
\hline $\mathrm{Al}_{2} \mathrm{O}_{3}$ & 12.48 & 13.56 & 12.95 & 12.90 & 11.64 & 11.40 & 10.74 & 9.86 & 13.95 & 15.95 & 12.01 & 16.18 \\
\hline $\mathrm{Fe}_{2} \mathrm{O}_{3}$ & 8.78 & 8.02 & 7.84 & 8.61 & 10.21 & 8.03 & 8.78 & 10.10 & 8.54 & 10.28 & 8.12 & 8.80 \\
\hline $\mathrm{MnO}$ & 0.13 & 0.15 & 0.15 & 0.15 & 0.15 & 0.13 & 0.14 & 0.14 & 0.14 & 0.11 & 0.16 & 0.18 \\
\hline $\mathrm{MgO}$ & 13.51 & 11.45 & 13.60 & 12.19 & 9.94 & 11.51 & 14.55 & 12.15 & 10.02 & 8.25 & 11.95 & 10.64 \\
\hline $\mathrm{CaO}$ & 5.46 & 6.84 & 6.97 & 12.73 & 6.82 & 5.08 & 7.08 & 6.35 & 7.85 & 7.53 & 12.50 & 9.26 \\
\hline $\mathrm{Na}_{2} \mathrm{O}$ & 3.30 & 2.87 & 2.87 & 2.27 & 2.42 & 2.24 & 0.62 & 1.86 & 2.86 & 2.12 & 0.89 & 0.89 \\
\hline $\mathrm{K}_{2} \mathrm{O}$ & 0.69 & 0.44 & 0.22 & 0.28 & 0.66 & 0.65 & 0.74 & 0.55 & 1.02 & 1.15 & 0.05 & 0.70 \\
\hline $\mathrm{P}_{2} \mathrm{O}_{5}$ & 0.03 & 0.01 & 0.04 & 0.04 & 0.01 & 0.04 & 0.05 & 0.08 & 0.04 & 0.04 & 0.21 & 0.02 \\
\hline LOI & 4.33 & 2.8 & 2.56 & 5.46 & 4.43 & 2.96 & 2.96 & 3.6 & 3.16 & & 4.01 & \\
\hline $\mathrm{Sc}$ & 29.0 & 29.2 & 33.7 & 27.1 & 30.3 & 22.8 & & 25.0 & 29.0 & & & 37.9 \\
\hline $\mathrm{Cr}$ & 1036 & 543 & 786 & 762 & 481 & 722 & 1136 & 1404 & 566 & 276 & 659 & 416 \\
\hline V & 166 & 171 & 202 & 193 & 176 & 126 & 144 & 111 & 212 & 199 & 256 & 265 \\
\hline $\mathrm{Ni}$ & 306 & 157 & 296 & 374 & 103 & 234 & 337 & 669 & 186 & 71 & 205 & 113 \\
\hline Co & 45.0 & 36.3 & 38.5 & 44.6 & 35.0 & & & 85.0 & & 39.0 & & 19.1 \\
\hline $\mathrm{Cu}$ & 60 & 40 & 56 & 27 & 89 & 39 & 65 & 42 & 57 & 45 & 157 & \\
\hline $\mathrm{Zn}$ & 63 & 71 & 58 & 57 & 66 & 39 & 66 & 42 & 65 & 86 & 54 & 134 \\
\hline $\mathrm{Rb}$ & 6.4 & 5.7 & 3.1 & 7.6 & 13.0 & 9.9 & 9.7 & 13.8 & 9.1 & 14.9 & 1.0 & 2.2 \\
\hline $\mathrm{Sr}$ & 107 & 165 & 136 & 139 & 86 & 154 & 72 & 46 & 97 & 101 & 133 & 58 \\
\hline $\mathrm{Y}$ & 7.2 & 5.1 & 6.5 & 8.2 & 4.0 & 4.0 & 5.3 & 4.2 & 14.3 & 5.6 & 15.7 & 10.6 \\
\hline $\mathrm{Zr}$ & 35 & 40 & 27 & 26 & 27 & 41 & 30 & 22 & 47 & 37 & 20 & 12 \\
\hline $\mathrm{Nb}$ & 0.53 & 0.62 & 0.44 & 0.53 & 0.66 & 0.49 & 0.50 & 0.41 & 2.36 & 2.20 & 0.23 & 0.11 \\
\hline $\mathrm{Ba}$ & 47 & 19 & 7.6 & 15 & 35 & 36.02 & 17.7 & 12.4 & 70.1 & 16 & 13.2 & 7.1 \\
\hline $\mathrm{La}$ & 1.81 & 1.31 & 1.15 & 1.50 & 0.86 & & 1.27 & 0.54 & 3.22 & 0.52 & 0.99 & 0.38 \\
\hline $\mathrm{Ce}$ & 3.86 & 3.37 & 2.57 & 3.05 & 1.80 & 4.14 & 2.98 & 1.87 & 7.36 & 2.00 & 2.18 & 0.89 \\
\hline Pr & 0.59 & 0.48 & 0.37 & 0.50 & 0.24 & 0.54 & 0.40 & 0.27 & 1.05 & 0.40 & 0.16 & \\
\hline $\mathrm{Nd}$ & 2.84 & 2.32 & 1.97 & 2.61 & 1.24 & 2.30 & 1.72 & 1.46 & 5.00 & 1.54 & 2.46 & 0.94 \\
\hline $\mathrm{Sm}$ & 0.81 & 0.61 & 0.61 & 0.80 & 0.47 & 0.64 & 0.58 & 0.43 & 1.36 & 0.53 & 0.99 & 0.53 \\
\hline $\mathrm{Eu}$ & 0.27 & 0.24 & 0.22 & 0.31 & 0.14 & 0.21 & 0.18 & 0.12 & 0.46 & 0.20 & 0.37 & 0.24 \\
\hline Gd & 0.97 & 0.78 & 0.81 & 1.06 & 0.46 & 0.59 & 0.62 & 0.48 & 1.60 & 1.35 & 0.87 & \\
\hline $\mathrm{Tb}$ & 0.16 & 0.14 & 0.15 & 0.20 & 0.08 & 0.15 & 0.14 & 0.10 & 0.36 & 0.14 & 0.26 & 0.19 \\
\hline Dy & 1.05 & 0.84 & 1.00 & 1.30 & 0.62 & 0.71 & 0.84 & 0.62 & 2.39 & 1.62 & 1.40 & \\
\hline Ho & 0.23 & 0.17 & 0.21 & 0.30 & 0.13 & 0.13 & 0.20 & 0.13 & 0.54 & 0.37 & 0.33 & \\
\hline $\mathrm{Er}$ & 0.69 & 0.56 & 0.72 & 0.84 & 0.48 & 0.43 & 0.51 & 0.40 & 1.53 & 0.99 & 1.07 & \\
\hline $\mathrm{Tm}$ & 0.11 & 0.10 & 0.12 & 0.14 & 0.07 & 0.07 & 0.10 & 0.06 & 0.25 & 0.23 & 0.17 & \\
\hline $\mathrm{Yb}$ & 0.80 & 0.70 & 0.75 & 0.87 & 0.68 & 0.49 & 0.69 & 0.46 & 1.60 & 0.68 & 1.14 & 1.22 \\
\hline $\mathrm{Lu}$ & 0.14 & 0.11 & 0.11 & 0.13 & 0.12 & 0.11 & 0.09 & 0.08 & 0.27 & 0.11 & 0.19 & 0.17 \\
\hline $\mathrm{Hf}$ & 0.90 & 1.02 & 0.70 & 0.70 & 0.75 & 1.12 & 0.63 & 0.61 & 1.45 & 0.80 & 0.60 & 1.29 \\
\hline $\mathrm{Ta}$ & 0.03 & 0.03 & 0.03 & 0.02 & 0.06 & 0.05 & 0.09 & 0.03 & 0.16 & 0.06 & 0.01 & 0.04 \\
\hline $\mathrm{Pb}$ & 1.50 & 2.37 & 0.72 & 0.84 & 1.51 & 1.99 & 1.22 & 0.67 & 1.82 & 1.79 & & \\
\hline Th & 0.27 & 0.34 & 0.17 & 0.18 & 0.16 & 0.23 & 0.08 & 0.12 & 0.68 & 0.13 & & 0.46 \\
\hline $\mathrm{U}$ & 0.18 & 0.13 & 0.12 & 0.14 & 0.13 & 0.21 & 0.09 & 0.18 & 0.38 & 0.16 & & 0.19 \\
\hline \multicolumn{13}{|c|}{ Chondrite normalized } \\
\hline $\mathrm{La}$ & 5.84 & 4.23 & 3.71 & 4.84 & 2.77 & 4.10 & 1.74 & 10.39 & 1.68 & 3.19 & 1.23 & \\
\hline $\mathrm{Ce}$ & 4.78 & 4.17 & 3.18 & 3.77 & 2.23 & 5.12 & 3.69 & 2.31 & 9.11 & 2.48 & 2.70 & 1.10 \\
\hline $\mathrm{Pr}$ & 4.84 & 3.93 & 3.03 & 4.10 & 1.97 & 4.43 & 3.28 & 2.21 & 8.61 & 3.28 & 1.31 & \\
\hline $\mathrm{Nd}$ & 4.73 & 3.87 & 3.28 & 4.35 & 2.07 & 3.83 & 2.87 & 2.43 & 8.33 & 2.57 & 4.10 & 1.57 \\
\hline $\mathrm{Sm}$ & 4.15 & 3.13 & 3.13 & 4.10 & 2.41 & 3.28 & 2.97 & 2.21 & 6.97 & 2.72 & 5.08 & 2.72 \\
\hline $\mathrm{Eu}$ & 3.67 & 3.27 & 2.99 & 4.22 & 1.90 & 2.86 & 2.45 & 1.63 & 6.26 & 2.72 & 5.03 & 3.27 \\
\hline Gd & 3.75 & 3.01 & 3.13 & 4.09 & 1.78 & 2.28 & 2.39 & 1.85 & 6.18 & 5.21 & 3.36 & \\
\hline $\mathrm{Tb}$ & 3.38 & 2.95 & 3.16 & 4.22 & 1.69 & 3.16 & 2.95 & 2.11 & 7.59 & 2.95 & 5.49 & 4.01 \\
\hline Dy & 3.26 & 2.61 & 3.11 & 4.04 & 1.93 & 2.20 & 2.61 & 1.93 & 7.42 & 5.03 & 4.35 & \\
\hline Ho & 3.20 & 2.37 & 2.92 & 4.18 & 1.81 & 1.81 & 2.79 & 1.81 & 7.52 & 5.15 & 4.60 & \\
\hline $\mathrm{Er}$ & 3.29 & 2.67 & 3.43 & 4.00 & 2.29 & 2.05 & 2.43 & 1.90 & 7.29 & 4.71 & 5.10 & \\
\hline $\mathrm{Tm}$ & 3.40 & 3.09 & 3.70 & 4.32 & 2.16 & 2.16 & 3.09 & 1.85 & 7.72 & 7.10 & 5.25 & \\
\hline $\mathrm{Yb}$ & 3.83 & 3.35 & 3.59 & 4.16 & 3.25 & 2.34 & 3.30 & 2.20 & 7.66 & 3.25 & 5.45 & 5.84 \\
\hline Lu & 4.35 & 3.42 & 3.42 & 4.04 & 3.73 & 3.42 & 2.80 & 2.48 & 8.39 & 3.42 & 5.90 & 5.28 \\
\hline
\end{tabular}

${ }^{2}$ Data are from publications cited in the text, augmented by unpublished XRF major and trace element data (analyzed by R.J.A. at UNE) and ICP-MS trace element data (analyzed by J.A.P. and D.W.P. at Durham). 

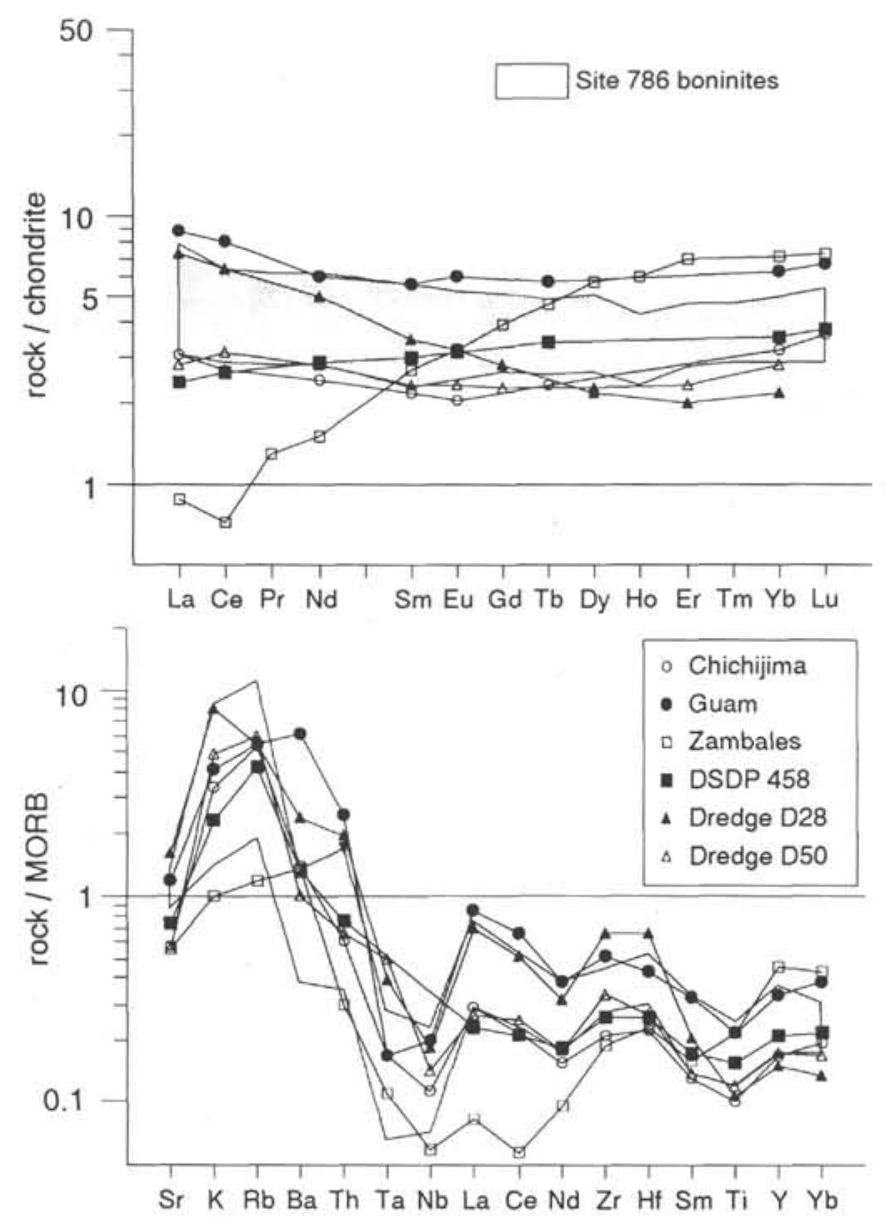

Figure 27. REE and trace element patterns for boninite and tholeiite samples from other parts of the Western Pacific Eocene province showing the comparison with Leg 125 data.

be explained by cooling of the mantle wedge after the initiation of subduction so that the shallowest levels are no longer fusible by the early Oligocene.

In summary, the change from a transform to compressional plate margin may provide a wide range of settings for boninite genesis and, hence, a wide range of petrogenetic histories. Ridge subduction, subduction beneath active ridges, and subduction of young lithosphere beneath young lithosphere are all likely processes and will, in detail, give different boninite types. Further work, and further drilling, are, however, needed to deduce the precise geometrical relationships between the boninite provinces.

\section{CONCLUSIONS}

1. During Leg 125, scientists sampled the Izu-Bonin and Mariana forearc basement at a number of sites. Site 786 penetrated an Eocene boninitic edifice cut by dikes and sills mainly of early Oligocene ages. Site 782 penetrated early Oligocene tholeiitic andesite and dacite. Sites 778-780 and 783-784 penetrated residual peridotites.

2. The boninitic edifice at Site 786 is made up of a basement of low-Ca bronzite andesite dikes and low-Ca boninite pillow lavas and hyaloclastite overlain by lavas and breccia, and cut by dikes, of intermediate-Ca bronzite andesite, andesite, dacite and rhyolite. These rocks are all slightly radiogenic (in $\mathrm{Pb}$ and $\mathrm{Sr}$ ) relative to MORB mantle and are all characterized by high $\mathrm{Zr} / \mathrm{Sm}$ and $\mathrm{Zr} / \mathrm{Ti}$ ratios relative to MORB, volcanic arc or ocean island basalt.
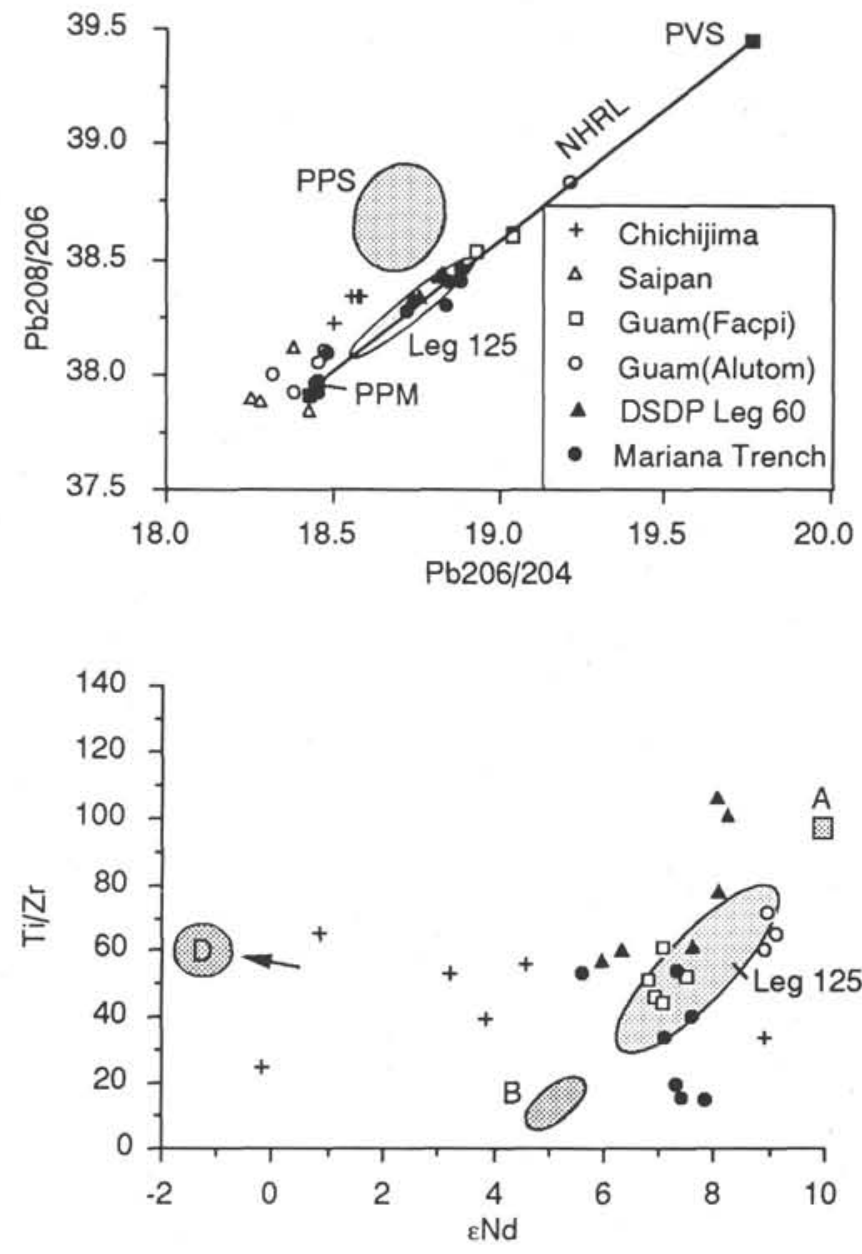

Figure 28. Lead isotope and $\mathrm{Ti} / \mathrm{Zr}-\varepsilon \mathrm{Nd}$ diagrams for boninite and tholeiite samples from other parts of the Western Pacific Eocene province showing the comparison with Leg 125 data.

3. Experimental data indicate that the primary boninite magma originated at high temperatures (on the order of $1250^{\circ} \mathrm{C}$ ) and segregated at very low pressures. The volatile studies of Newman and Van der Laan (this volume) constrain the water content of the boninite mantle source to values on the order of $0.15 \pm 0.075 \mathrm{wt} \%$.

4. The mantle source prior to subduction can be inferred from $\mathrm{TiO}_{2}-\mathrm{Mg} \#$ covariations, to be the depleted mantle of clinopyroxenepoor lherzolite composition that had lost up to nearly $20 \%$ melt compared with a fertile MORB mantle composition. The depletion of the source increases from tholeiite through high-Ca boninite to intermediate-Ca boninite to low-Ca boninite. This mantle source has the composition of MORB lithosphere unenriched by asthenospheric fluids.

5. Isotope data indicate two distinct subduction components. One (component C) contains only the most mobile elements (such as $\mathrm{Sr}$ ) of the type that is conventionally interpreted as an aqueous subduction fluid. The other (component B) contains both LIL and HFS elements and has not previously been defined in detail.

6. Subduction component B contains most elements except Ti, Y the middle-heavy REEs and compatible elements such as $\mathrm{Ni}, \mathrm{Cr}$, and $\mathrm{Sc}$. Water, alkali elements including $\mathrm{Na}$, alkaline earth elements, $\mathrm{Al}$ and $\mathrm{Pb}$, light-middle REEs, $\mathrm{Th}, \mathrm{Nb}, \mathrm{Ta}, \mathrm{Zr}$, and $\mathrm{Hf}$ all are enriched. Like subduction components from the active Izu-Bonin and Mariana arcs, they exhibit LIL element enrichment and negative anomalies of $\mathrm{Nb}$ and $\mathrm{Ta}$ relative to $\mathrm{Th}$ and La. Unlike these components, they exhibit high $\mathrm{Zr} / \mathrm{Sm}$ and $\mathrm{Zr} / \mathrm{Ti}$ ratios. Lead isotope data indicate that pelagic sediments were not the source of this component. Petrogenetic 

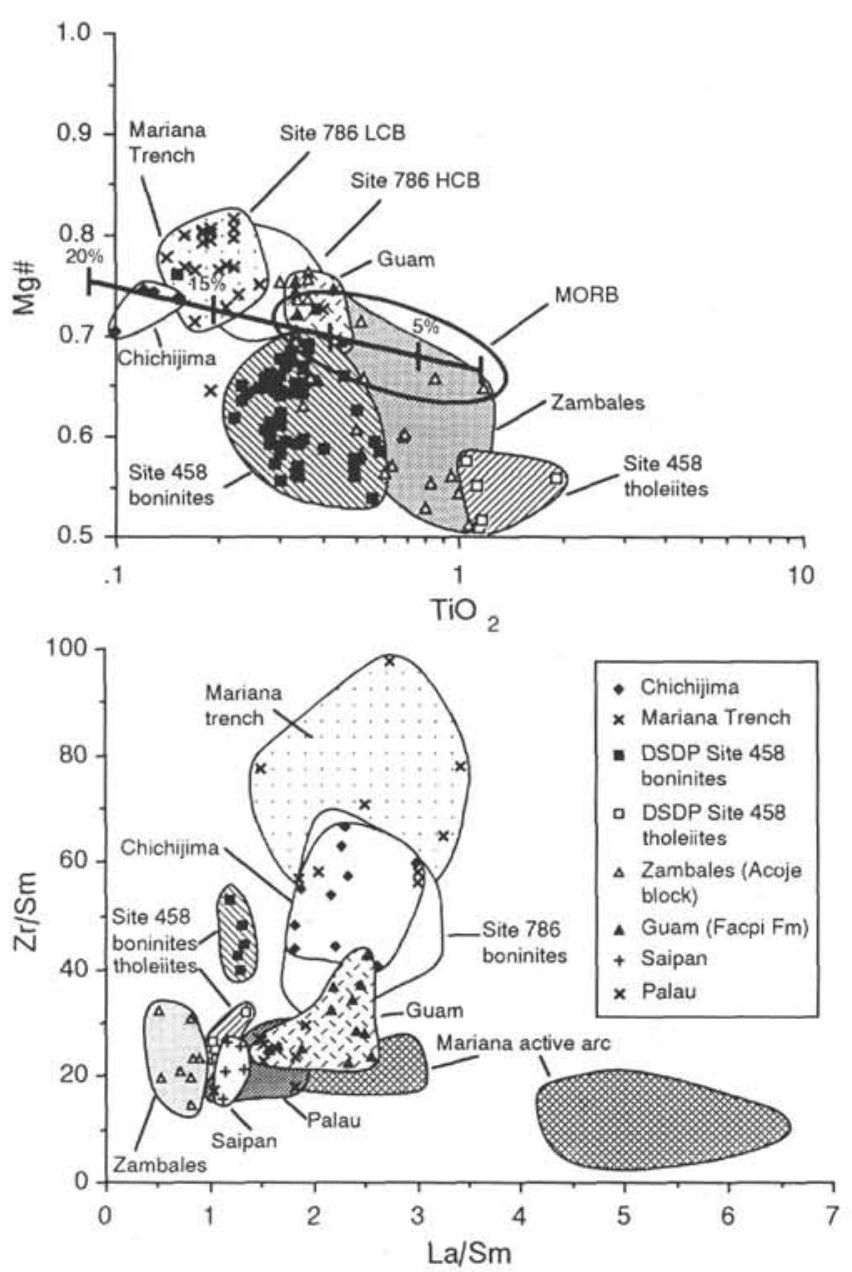

Figure 29. $\mathrm{Mg \# -TiO}$ and $\mathrm{Zr} / \mathrm{Sm}-\mathrm{La} / \mathrm{Sm}$ diagrams for boninite and tholeiite samples from other parts of the Western Pacific Eocene province showing the comparison with Leg 125 data. The annotated line in the upper diagram is the trend for pooled melts from variably depleted residues as defined in Figure 16.

modeling indicates that it may derive from trondhjemitic melt derived by partial fusion of subducted oceanic crust (MORB-OIB amphibolite). The isotopic composition of this component indicates an origin from Pacific, and not Indian or West Philippine Basin, oceanic crust, and/or seamounts and volcanogenic sediments.

7. The harzburgite has a similar enrichment pattern, but greater magnitude of enrichment, to the boninite, indicating that this subduction component continued to be added in the subsolidus state to the mantle residue from boninite genesis.

8. Most indicators (low modal clinopyroxene, Fo content of olivine between $91 \%$ and $92.5 \%$ ) point to a degree of melting on the order of $25 \%$ for the Leg 125 harzburgite. Experimental data and thermal constraints indicate that the average degree of melting required to form the boninite is on the order of $5 \%-10 \%$. The degree of partial melting is likely to have been smallest in the genesis of the low-Ca boninites, greatest in the genesis of the high-Ca boninite series. We infer that the low-Ca boninite formed by about $5 \%$ melting of fertile MORB mantle already depleted by the loss of about $15 \%$ of melt. The harzburgite could be the most depleted residue from this melting event, whereas the boninite is the pooled melt from a slightly more enriched average source.

9. Experimental data indicate that the harzburgite has lost almost the maximum amount of melt possible for an upwelling fertile MORB mantle diapir containing $0.2 \mathrm{wt} \%$ of water. Given the evidence that the melting took place in two stages, the second of which produced boninites, we consider it probable that the two stages were separated by a small time interval, so that the second stage of melting occurred before substantial cooling of the melt residue had taken place. The high temperatures of the boninite magma also indicate little cooling. Subduction beneath, or very close to, an active ridge best satisfies this criterion. Thermal modeling indicates that ridge subduction may be important but is unlikely to be the sole cause of boninite genesis. Nonetheless, the absence of a subducted sediment component in the boninite and the evidence for slab melting indicate that the subducted crust also was young. Subduction of young lithosphere into young mantle is met during the transition from an active ridge-transform to subduction system, as proposed by Casey and Dewey (1984).

10. The Leg 125 boninite and harzburgite are typical of the Eocene western Pacific province. In detail, however, there are significant differences in space and time within the province that still require a tectonic explanation.

\section{ACKNOWLEDGMENTS}

J.A.P., B.J.M., and D.W.P. are grateful to the Natural Environment Research Council (U.K.) for an Ocean Drilling Special Topics research grant (GR3/416), and I.J.P. for a research studentship. R.J.A. and S.v.d.L. thank USAAC for logistic and analytical funds. We are all grateful to Patty Fryer, Laura Stokking, and the other shipboard scientists, the marine technicians and the captain and crew of the JOIDES Resolution for their help and company during Leg 125 . We also thank the collaborators on the papers from which we synthesized part of this work, including Matthew Thirlwall, John Mitchell, Gerry Ingram, Sally Newman, and Yves Lagabrielle. Bob Jackson (UDIRL, Durham) provided assistance with the ICP-MS, and the University of Durham Research Committee provided financial assistance with sample-dissolution apparatus. J.A.P. thanks Paul Browning and Martin Bott for help and advice on the computer modeling and Huw Davis, Mike Bickle, Bob Stern, Rex Taylor, Bob Nesbitt, Lynn Johnson, Brian Taylor, and Michael Wolf for preprints and discussion of their work. Roger Haston, Shige Maruyama, Jun Yumul, and Sorena Sorenson (from the Smithsonian Collection) provided samples for regional comparison. We thank Dave Scholl and Bob Stern for their constructive reviews of the chapter.

\section{REFERENCES}

Allen, J. C., and Boettcher, A. L., 1978. Amphiboles in andesite and basalt: II. Stability as a function of P-T- $\mathrm{f}_{\mathrm{H} 2} \mathrm{O}-\mathrm{f}_{\mathrm{O} 2}$. Am. Mineral., 63: 1074-1087.

Aoki, H., and Ishikawa, M., 1985. On the igneous rocks dredged in the Daito Ridge Group and the Kyushu-Palau Ridge in the GDP cruises. In Shiki, T. (Ed.), Geology of the Northern Philippine Sea: Tokyo (Tokai University Press), 42-49.

Arth, J. G., and Hanson, G. N., 1975. Geochemistry and origin of the early Precambrian crust of northeastern Minnesota. Geochim. Cosmochim. Acta, $39: 325-362$.

Beard, J. S., and Lofgren, G. G., 1991. Dehydration melting and water-saturated melting of basaltic and andesitic greenstones and amphibolites at 1 , 3 and 6.9 kb. J. Petrol., 32:365-401.

Beccaluva, L., and Serri, G., 1988. Boninitic and low-Ti subduction-related lavas from intraoceanic arc-basin systems and low-Ti ophiolites: a reappraisal of their petrogenesis and original tectonic setting. Tectonophysics, 146:291-315.

Beccaluva, L., Macciotta, G., Savelli, C., Serri, G., and Zeda, O., 1980. Geochemistry and K/Ar ages of volcanics dredged in the Philippine Sea (Mariana, Yap and Palau Trenches and Parece Vela Basin). In Hayes, D. E. (Ed.), The Tectonic and Geologic Evolution of Southeast Asian Seas and Islands. AGU Geophysical Monograph 23: Washington (American Geophysical Union), 247-268.

Bloomer, S., 1983. Distribution and origin of igneous rocks from the landward slopes of the Mariana Trench: implications for its structure and evolution. J. Geophys. Res., 88:7411-7428. 
Bloomer, S., and Hawkins, J. W., 1983. Gabbroic and ultramafic rocks from the landward slopes of the Mariana Trench: implications for its structure and evolution. In Hayes, D. E. (Ed.), The Tectonic and Geologic Evolution of Southeast Asian Seas and Islands. AGU Geophysical Monograph 23: Washington (American Geophysical Union), 294-317.

Bloomer, S., and Hawkins, J. W., 1987. Petrology and geochemistry of boninite series volcanic rocks from the Mariana Trench. Contrib. Mineral. Petrol., 97:361-377.

Bogdanov, N., and the R/V Dmitry Mendeleev Scientific Staff, 1977. Initial reports of the geological study of oceanic crust of the Philippine sea floor. Ofioliti, 2:137-168.

Bonatti, E., and Michael, P. J., 1989. Mantle peridotites from continental rifts to ocean basins to subduction zones. Earth Planet. Sci. Lett., 91:297-311.

Brophy, J. G., and Marsh, B. D., 1986. On the origin of high-alumina basalt and the mechanics of melt extraction. J. Petrol., 27:763-789.

Cameron, W. E., McCulloch, M. T., and Walker, D. A., 1983. Boninite petrogenesis: chemical and $\mathrm{Nd}-\mathrm{Sr}$ isotopic constraints. Earth Planet. Sci. Lett., 65:75-89.

Cann, J. R., 1979. Metamorphism in the oceanic crust. Deep Drilling Results in the Atlantic Ocean: Ocean Crust. Maurice Ewing Series 2: Washington (American Geophysical Union), 230-238.

Casey, J. F., and Dewey, J. F., 1984. Initiation of subduction zones along transform and accreting plate boundaries, triple-junction evolution and forearc spreading centres-implications for ophiolitic geology and obduction. Geol. Soc. Lond. Spec. Publ., 13:269-290.

Clague, D. A., and Dalrymple, G. B., 1987. The Hawaiian-Emperor volcanic chain. Part I. Geologic evolution. In Decker, R. W., Wright, T. L., and Stauffer, P. H. (Eds.), Volcanism in Hawaii (Vol. 1): U.S. Geol. Surv. Prof. Pap., 1350, 5-54.

Cloud,P. E., Jr., Schmidt, R. G., and Burke, H. W., 1956. Geology of Saipan, Mariana Islands. U.S. Geol. Surv. Prof. Pap., 280-A, 126 pp.

Crawford, A. J. (Ed.), 1989. Boninites and Related Rocks: London (Unwin Hyman), $465 \mathrm{p}$

Crawford, A. J., Beccaluva, L., Serri, G., and Dostal, J., 1986. Petrology, geochemistry and tectonic implications of volcanics dredged from the intersection of the Yap and Mariana trenches, Earth Planet. Sci. Lett., $80: 265-280$.

Crawford, A. J., Falloon, T. J., and Green, D. H., 1989. Classification, petrogenesis and tectonic setting of boninites. In Crawford, A. J. (Ed.), Boninites and Related Rocks: London (Unwin Hyman), 1-49.

Davis, J. H., and Bickle, M. J., in press. A physical model for the volume and composition of melt produced by hydrous fluxing above subduction zones. Phil. Trans. R. Soc. Lond.

Davis, J. H., and Stevenson, D. J., in press. Physical model of source region of subduction zone volcanics. J. Geophys. Res.

Defant, M. J., and Drummond, M. S., 1990. Derivation of some modern arc magmas by melting of young subducted lithosphere. Nature, 347:662-665.

Delaney, J. M., and Helgeson, H. C., 1978. Calculation of the thermodynamic consequences of dehydration in subducting oceanic crust to $100 \mathrm{~kb}$ and $>800^{\circ} \mathrm{C}$. Am. J. Sci., 278:638-686.

DeLong, S. E., Schwarz, W. M., and Anderson, R. N., 1979. Thermal effects of ridge subduction. Earth Planet. Sci. Lett., 44:239-246.

De Wit, M. J., Armstrong, R., Hart, R. J., and Wilson, A. H., 1987. Felsic igneous rocks within the $3.3-$ to $3.5-\mathrm{Ga}$ Barberton greenstone belt: high crustal level equivalents of the surrounding tonalite-trondhjemite terrane emplaced during thrusting. Tectonics, 6:529-549.

Dick, H.J.B., 1989. Abyssal peridotites, very slow spreading ridges and ocean ridge magmatism. Geol. Soc. Lond. Spec. Publ., 42:71-105.

Dick, H.J.B., and Bullen, T., 1984. Chromian spinel as a petrogenetic indicator in abyssal and alpine-type peridotites and spatially associated lavas. Contrib. Mineral. Petrol., 86:54-76.

Dietrich, V. R., Emmermann, J., Keller, J., and Puchelt, H., 1977. Geochemistry of basaltic and gabbroic rocks from the West Mariana Basin and the Mariana Trench. Earth Planet. Sci. Lett., 39:127-144.

Dobson, P. F., 1986. The petrogenesis of boninite: a field, petrologic and geochemical study of the volcanic rocks of Chichi-jima, Bonin Islands, Japan. [Ph.D. dissert.]. Stanford University.

Dobson, P. F., and O'Neill, J. R., 1987. Stable isotope compositions and water contents of boninite series volcanic rocks from Chichi-Jima, Bonini Islands, Japan. Earth Planet. Sci. Lett., 82:75-86.

Dobson, P. F., and Tilton, G. R., 1989. Stable isotope compositions and water contents of boninite series volcanic rocks from Chichi-Jima, Bonin Islands,
Japan. In Crawford, A. J. (Ed.) Boninites and Related Rocks : London (Unwin Hyman), 369-415.

Dostal, J., Dupuy, C., Carron, J. P., Le Guen de Kerneizon, M., and Maury, R. C., 1983. Partition coefficients of trace elements: application to volcanic rocks of St. Vincent, West Indies. Geochim. Cosmochim. Acta, 47:525-533.

Drummond, M. S., and Defant, M. J., in press. A model for trondhjemitetonalite-dacite genesis and crustal growth via slab melting: Archaean to modern comparisons. J. Geophys. Res.

Duncan, R. A., and Green, D. H., 1980. Role of multi-stage melting in the formation of oceanic crust. Geology, 8:22-36.

1987. The genesis of refractory melts in the formation of oceanic crust. Contrib. Mineral. Petrol., 96:326-342.

Engebretson, D. C., Cox, A., and Gordon, R. G., 1985. Relative motions between oceanic and continental plates in the Pacific basin. Geol. Soc. Am. Spec. Paper, 206:59 p.

Falloon, T. J., Green, D. H., Hatton, C. J., and Harris, K. L., 1988. Anhydrous partial melting of a fertile and depleted peridotite from 2 to $30 \mathrm{~kb}$ and application to basalt petrogenesis. J. Petrol., 29:1257-1282.

Falloon, T. J., Green, D. H., and McCulloch, M. T., 1989. Petrogenesis of high-Mg and associated lavas from the north Tonga Trench. In Crawford, A. J. (Ed.), Boninites and Related Rocks: London(Unwin Hyman), 357-395.

Fox, P. J., Pitman, W. C., II, and Shepard, F., 1969. Crustal plates in the Central Atlantic: evidence for at least two poles of rotation. Science, 165:487-489.

Frey, F. A., Suen, C. J., and Stockman, H. W., 1985. The Ronda high temperature peridotite: geochemistry and petrogenesis. Geochim. Cosmochim. Acta, 49:2469-2491.

Fryer, P., Ambros, E. L., and Hussong, D. M., 1985. Origin and emplacement of Mariana forearc seamounts. Geology, 13:774-777.

Fryer, P., Pearce, J. A., Stokking, L. B., et al., 1990. Proc. ODP, Init. Repts., 125: College Station, TX (Ocean Drilling Program).

Fujii, T., and Scarfe, C. M., 1985. Composition of liquids coexisting with spinel lherzolite at $10 \mathrm{kbar}$ and the genesis of MORBs. Contrib. Mineral. Petrol., 90:18-28.

Fuller, M., Haston, R., and Almasco, J., 1989. Paleomagnetism of the Zambales ophiolite, Luzon, northern Philippines. Tectonophysics, 168:171-203.

Geary, E. E., Kay, R. W., Reynolds, J. C., and Kay, S. M., 1989. Geochemistry of mafic rocks from the Coto Block, Zambales ophiolite, Philippines: trace element evidence for two stages of crustal growth. Tectonophysics, 168:43-63.

Green, D. H., 1970. The origin of basaltic and nephelinitic magmas. Trans. Leics. Lit. Phil. Soc., 64:28-54.

1973. Experimental melting studies on a model upper mantle composition at high pressure under water-saturated and water-undersaturated conditions. Earth Planet. Sci. Lett., 19:37-53.

1976. Experimental testing of "equilibrium" partial melting of peridotite under water-saturated, high pressure conditions. Canad. Mineral., 14:255-268.

Hart, S. R., 1984. A large-scale isotope anomaly in the Southern hemisphere mantle. Nature, 309:753-757.

Hawkins, J. W., and Evans, C. A., 1983. Geology of the Zambales Range, Luzon, Philippine Islands: ophiolite derived from an island arc-back-arc basin pair. In Hayes, D. E. (Ed.), The Tectonic and Geologic Evolution of Southeast Asian Seas and Islands, Part II. AGU Geophysical Monograph 27: Washington (American Geophysical Union), 95-123.

Hawkins, J. W., Bloomer, S. H., Evans, C. A., and Melchior, J. T., 1984. Evolution of intra-oceanic, arc-trench systems. Tectonophysics, 102:175-205.

Helz, R. T., 1973. Phase relations of basalts in their melting ranges at $\mathrm{p}_{\mathrm{H}_{2} \mathrm{O}}=$ $5 \mathrm{~kb}$ as a function of oxygen fugacity. Part I. Mafic phases. J. Petrol., $14: 249-302$

, 1976. Phase relations of basalts in their melting ranges at $\mathrm{p}_{\mathrm{H}_{2} \mathrm{O}}=$ 5 kb. Part II. Melt compositions. J. Petrol., 17:139-193.

Hickey, R. L., and Frey, F. A., 1982. Rare-earth element geochemistry of Mariana forearc volcanics: Deep Sea Drilling Project Site 458 and Hole 459B. In Hussong, D. M., Uyeda, S., et al., Init. Repts. DSDP, 60: Washington (U.S. Govt. Printing Office), 735-742.

Hickey-Vargas, R., 1989. Boninites and tholeiites from DSDP Site 458, Mariana forearc. In Crawford, A. J. (Ed.), Boninites and Related Rocks: London (Unwin Hyman), 339-356.

Hickey-Vargas, R. L., and Reagan, M. K., 1987. Temporal variations of isotope and rare earth element abundances from Guam: implications for the evolution of the Mariana arc. Contrib. Mineral. Petrol., 97:497-508.

Hilde, T., Uyeda, S., and Kroenke, L., 1977. Evolution of the western Pacific and its margin. Tectonophysics, 38:145-165. 
Hilde, T.W.C., and Lee, C.-S., 1984. Origin and evolution of the West Philippine Basin: a new interpretation. Tectonophysics, 102:85-104.

Holloway, J. R., and Burnham, C. W., 1972. Melting relations of basalt with equilibrium water pressure less than total pressure. J. Petrol., 13:1-29.

Honza, E., and Tamaki, K., 1985. Bonin arc. In Nairn, A.E.M. and Uyeda, S. (Eds.), The Ocean Basins and Margins (Vol. 7,) The Pacific Ocean: New York (Plenum Press), 459-499.

Honza, E., 1991. The Tertiary arc chain in the western Pacific. Tectonophysics, 187:285-303.

Hsui, A. T., and Toksöz, M. N., 1979. The evolution of thermal structures beneath a subduction zone. Tectonophysics, 60:43-60.

Hussong, D. M., and Uyeda, S., 1981. Tectonic processes and the history of the Mariana arc: a synthesis of the results of Deep Sea Drilling Project Leg 60. In Hussong, D. M., Uyeda, S., et al., Init. Repts. DSDP, 60: Washington (U.S. Govt. Printing Office), 909-929.

Irving, A. J., 1978. A review of experimental studies of crystal/liquid trace element partitioning. Geochim. Cosmochim. Acta, 42:743-770.

Irving, A. J., and Frey, F. A., 1984. Trace element abundances in megacrysts and their host basalt: constraints on partition coefficients and megacryst genesis. Geochim. Cosmochim. Acta, 48:1201-1221.

Ishii, T., 1985. Dredged samples from the Ogasawara fore-arc seamount or "Ogasawara Paleoland" fore-arc ophiolite. In Nasu, N. (Ed.), Formation of active ocean margins: Tokyo (TERRAPUB), 307-342.

Ishii, T., Konishi, K., Naka, J., Futakuchi, K., and Ohara, H., 1983. Description of samples from Ogasawara forearc seamount or "Ogasawara Paleoland." In Kobayashi, K. (Ed.), Preliminary Report of the Hakuho Maru cruise KH80-3: Tokyo (Ocean Research Institute), 173-186.

Ishii, T., Konishi, K., and Omura, A., 1981. Description of samples. In Kobayashi, K. (Ed.), Preliminary Report of the Hakuho Maru cruise KH82-4: Tokyo (Ocean Research Institute), 105-165.

Ishiwatari, A., 1985. Igneous petrogenesis of the Yakuno ophiolite (Japan) in the context of the diversity of ophiolites. Contrib. Mineral. Petrol., 89:155-167.

Jaques, A. L., and Green, D. H., 1980. Anhydrous melting of peridotite at 0-15 $\mathrm{kb}$ pressure and the genesis of tholeiitic basalts. Contrib. Mineral. Petrol. 73:287-310.

Johnson, K.T.M., and Nakamura, Y., 1985. Major, trace and rare earth element abundances in boninitic lavas from dredge 7. In Kobayashi, K. (Ed.), Preliminary Report of the Hakuho Maru cruise KH82-4: Tokyo (Ocean Research Institute), 202-214.

Johnson, K.T.M., Dick, H.J.B., and Schimizu, N., 1989. Melting in the oceanic upper mantle: an ion microprobe study of diopside in abyssal peridotites. J. Geophys. Res., 95: 2661-2678.

Johnson, L. E., and Fryer, P., 1990. The first evidence for MORB-like lavas from the outer Mariana forearc: geochemistry, petrography and tectonic implications. Earth Planet. Sci. Lett., 100:304-316.

Johnson, L. E., Fryer, P., Taylor, B., Solk, M., Jones, D. L., Sliter, W. V., Itaya, T., and Ishii, T., 1991. New evidence for crustal accretion in the outer Mariana forearc: Cretaceous radiolarian cherts and mid-ocean ridge basalt-like lavas. Geology, 19:811-814.

Johnson, R. W., Jaques, A. L., Langmuir, C. H., Perfit, M. R., Staudigel, H., Dunkley, P. N., Chappell, B. W., Taylor, S. R. and Baekisapa, M., 1987. Ridge subduction and forearc volcanism: petrology and geochemistry of rocks dredged from the Western Solomon arc and Woodlark Basin. In Taylor, B., and Exon, N. F. (Eds.), Circum-Pacific Council for Energy and Mineral Resources Earth Science Series 7: Houston (Circum-Pacific Council for Energy and Mineral Resources), 155-226.

Karig, D. E., Anderson, R. N., and Bibee, L. D., 1978. Characteristics of back-arc spreading in the Mariana Trough. J. Geophys. Res., 83:1213-1226.

Karig, D. E., 1982. Initiation of subduction zones: implications for arc evolution and ophiolite development. Geol. Soc. Lond. Spec. Publ., 10:563-576.

Kay, R. W., 1978. Aleutian magnesian andesites: melts from subducted Pacific ocean crust. J. Volcanol. Geotherm. Res., 4: 117-132.

Kobayashi, K., and Nakada, M., 1979. Magnetic anomalies and tectonic evolution of the Shikoku inter-arc basin. In Uyeda, S., et al. (Eds.), Advances in Earth and Planetary Sci., 6:391-402.

Kodama, K., Keating, B. H., and Helsley, C. E., 1983. Paleomagnetism of the Bonin Islands and its tectonic significance. Tectonophysics, 95:25-42.

Lee, C. S., and Hilde, T.W.C., 1982. Entrapment and back-arc spreading origin of the West Philippine Basin. Eos, 63:45.

Lewis, S. D., Mrozowski, C. L. and Hayes, D. E., 1982. The origin of the West Philippine Basin by inter-arc spreading. In Brace, G. R., and
Zanoria, A. S. (Eds.), Geology and tectonics of the of the Luzon-Marianas Region. Proc SEATAR Workshop on the Luzon Marianas transect, 1981. Manila.

Lin, P. N., Stern, R. J., and Bloomer, S. H., 1989. Shoshonitic volcanism in the northern Mariana arc, 2. Large-ion lithophile and rare earth element abundances: evidence for the source of incompatible element enrichments in intraoceanic arcs. J. Geophys. Res., 94:4497-4514.

Liou, J. G., Kuniyoshi, S., and Ito, K., 1974. Experimental studies of the phase relations between greenschist and amphibolite in a basaltic system. Am. J. Sci., 613-632.

Louden, K. E., 1976. Magnetic anomalies in the West Philippines basin. AGU Monogr., 19: Washington, D.C. (Int. Woollard Symp.), 253-267.

, 1977. Paleomagnetism of DSDP sediments, phase shifting of magnetic anomalies, and rotation of the West Philippine Basin. J. Geophys. Res., 82:2989-3002.

Maruyama, S., and Kuramoto, T., 1981. Geology of Oto-jima, Ani-jima and Chichi-jima. Bull. Volc. Soc. Japan Ann. Mtg. (in Japanese), 26:146.

Mason, A.C.,Corwin,G., Rodgers, C.L.,Elmquist, O., Vessel, A. J., and McCracken, R. J., 1956. Military geology of the Palau Islands, Caroline Islands, report, Intelligence Div., Office of Eng. Headquarters, U.S. Army Forces Far East and Eighth U.S. Army (rear). Washington, D.C. (U.S. Geol. Survey).

McCabe, R., and Uyeda, S., 1983. Hypothetical model for the bending of the Mariana arc. In Hayes, D. E. (Ed.), The Tectonic and Geologic Evolution of Southeast Asian Seas and Islands: Part II. AGU Geophysical Monograph 27: Washington (American Geophysical Union), 281-293.

McKee, E. H., 1975. K-Ar ages of deep-sea basalts, Benham Rise, West Philippine Basin, Leg 31, Deep Sea Drilling Project. In Karig, D. E., and Ingle, J. C., Jr., et al., Init. Repts. DSDP, 31: Washington (U.S. Govt. Printing Office), 909-929.

McKenzie, D. P., 1984. The generation and compaction of partially molten rock. J. Petrol., 25:713-765.

McKenzie, D. P., and Bickle, M. J., 1988. The volume and composition of melt generated by extension of the lithosphere. J. Petrol., 29:625-679.

Meijer, A., 1975. $\mathrm{Pb}$ and $\mathrm{Sr}$ isotopic studies of igneous rocks cored during leg 31 of the Deep Sea Drilling Project. In Karig, D. E., and Ingle, J. C., Jr., et al., Init. Repts. DSDP, 31: Washington (U.S. Govt. Printing Office), 601-605.

, 1976. $\mathrm{Pb}$ and $\mathrm{Sr}$ isotopic data bearing on the origin of volcanic rocks from the Mariana island-arc system. Geol. Soc. Am. Bull., 87:358-369.

1980. Primitive arc volcanism and a boninitic series: examples from Western Pacific island arcs. In Hayes, D. E. (Ed.), The tectonic and geologic evolution of Southeast Asian Seas and Islands. AGU Geophysical Monograph 23: Washington (American Geophysical Union), 269-282.

1983. The origin of low-K rhyolites from the Mariana frontal arc. Contrib. Mineral. Petrol., 83:45-51.

Meijer, A., Reagan, M., Ellis, H., Shafiqullah, M., Sutter, J., Damon, P., and Kling, S., 1983. Chronology of volcanic events in the Eastern Philippine Sea. In Hayes, D. E. (Ed.), The Tectonic and Geologic Evolution of Southeast Asian Seas and Islands, Part II. AGU Geophysical Monograph 27: Washington (American Geophysical Union), 349-359.

Mysen, B. O., and Kushiro, I., 1977. Compositional variation of coexisting phases with degree of melting of peridotite in the upper mantle. Am. Miner., 62:843-865.

Natland, J. H., 1989. Partial melting of a lithologically heterogeneous mantle: inferences from crystallization histories of magnesian abyssal tholeiites from the Siqueiros Fracture Zone. Geol. Soc. Lond. Spec. Publ., 42:41-70.

Natland, J. H., and Tarney, J., 1981. Petrological evolution of the Mariana arc and back-arc basin system-a synthesis of drilling results in the South Philippine Sea. In Hussong, D. M., Uyeda, S., et al., Init. Repts. DSDP, 60: Washington (U.S. Govt. Printing Office), 877-908.

Navon, O., and Stolper,E., 1987. Geochemical consequences of melt percolation: the upper mantle as a chromatographic column. J. Geol., 95:285-307.

Ogawa, Y., and Naka, J., 1984. Emplacement of ophiolitic rocks in forearc areas: examples from Central Japan and Izu-Mariana-Yap system. Geol Soc. Lond. Spec. Publ., 13: 291-301.

Ogawa, Y., Naka, J., and Taniguchi, H., 1985. Ophiolite-based forearcs: a particular type of plate boundary. In Nasu, N. (Ed.), Formation of Active Ocean Margins: Tokyo (TERRAPUB), 719-746.

Ozima, M., Kaneoka, I., and Ujiie, H., 1977. ${ }^{40} \mathrm{Ar}-{ }^{39} \mathrm{Ar}$ age of rocks, and the development mode of the Philippine Sea. Nature, 267:816-818.

Peacock, S. M., 1987. Creation and preservation of subduction-related inverted metamorphic gradients. J. Geophys. Res., 92: 12763-12781. 
1990. Fluid processes in subduction zones. Science, 248:329-337.

Pearce, J. A., 1980. Geochemical evidence for the genesis and eruptive setting of lavas from Tethyan ophiolites. In Panayiotou, A. (Ed.), Proc. Int. Ophiolite Symp. Cyprus: Nicosia (Cyprus Geological Survey), 261-272.

, 1983. Role of the sub-continental lithosphere in magma genesis at active continental margins. In Hawkesworth, C. J., and Norry, M. J. (Eds.), Continental basalts and mantle xenoliths: Nantwich (Shiva), 230-249.

Pearce, J. A., Lippard, S. J., and Roberts, S., 1984. Characteristics and tectonic significance of supra-subduction zone ophiolites. Geol. Soc. Lond. Spec. Publ., 16:77-94.

Pearce, J. A., and Norry, M. J., 1979. Petrogenetic implications of Ti, Zr, Y and $\mathrm{Nb}$ variations in volcanic rocks. Contrib. Mineral. Petrol., 69:33-47.

Pedersen, R. B., and Malpas, J., 1984. The origin of oceanic plagiogranites from the Karmøy ophiolite, Western Norway. Contrib. Mineral. Petrol., $88: 36-52$.

Reagan, M., and Meijer, A., 1984. Geology and geochemistry of early arc volcanic rocks from Guam. Geol. Soc. Am. Bull., 95:701-713.

Rossman, D. L., Castañada, G. C., and Bacuta, G. C., 1989. Geology of the Zambales ophiolite, Luzon, Philippines. Tectonophysics, 168:1-22.

Schmidt, R. G., 1957. Petrology of the volcanic rocks. In Geology of Saipan, Mariana Islands, Part 2: U.S. Geol. Surv., 127-175.

Scott, D. R., and Stevenson, D. J., 1989. A self-consistent model of melting, magma migration and buoyancy-driven circulation beneath mid-ocean ridges. J. Geophys. Res., 94:2973-2988.

Scott, R., and Kroenke, L., 1980. Evolution of back-arc spreading and arc volcanism in the Philippine Sea: interpretation of Leg 59 DSDP results. In Hayes, D. E. (Ed.), The Tectonic and Geologic Evolution of Southeast Asian Seas and Islands. AGU Geophysical Monograph 27: Washington (American Geophysical Union), 283-291

Seno, T., and Maruyama, S., 1984. Paleogeographic reconstruction and origin of the Philippine Sea. Tectonophysics, 102:53-84.

Sharaki, K., Kuroda, N., Maruyama, S., and Urano, H., 1978. Evolution of the Tertiary volcanic rocks in the Izu-Mariana arc. Bull. Volcanol., 41: 548-562.

Shiki, T., Mizuno, A., and Kobayashi, K., 1985. Data listing of the bottom materials dredged and cored from the Northern Philippine Sea. In Shiki, T. (Ed.), Geology of the Northern Philippine Sea: Tokyo (Tokai University Press), 23-41.

Sorensen, S. S., 1988. Petrology of amphibolite-facies mafic and ultramafic rocks from the Catalina schist, southern California: metasomatism and migmatization in a subduction zone metamorphic setting. J. Metamorphic Geol., 6:405-435.

Sorensen, S. S., and Barton, M. D., 1987. Metasomatism and partial melting in a subduction complex: Catalina schist, southern California. Geology, 15:115-118.

Sorensen, S.S., and Grossman, J. N., 1989. Enrichment of trace elements in garnet amphibolites from a paleo-subduction zone: Catalina schist, southern California. Geochim. Cosmochim. Acta, 53:3155-3177.

Stern, R. J., Morris, J., Bloomer, S. H., and Hawkins, J. W., 1991. The source of the subduction component in convergent margin magmas: trace element and radiogenic isotope evidence from Eocene boninites, Mariana forearc. Geochim. Cosmochim. Acta, 55:1467-1481.

Sun, S.-S., and Nesbitt, R. W., 1978. Geochemical regularities and genetic significance of ophiolitic basalts. Geology, 6:689-693.

Tatsumi, Y., 1982. Origin of high-magnesian andesites in the Setouchi volcanic belt, southwest Japan, II, Melting phase relations at high pressures. Earth Planet. Sci. Lett., 60: 305-317.

, 1989. Migration of fluid phases and genesis of basalt magmas in subduction zones. J. Geophys. Res., 94:4697-4707.

Tatsumi, Y., and Maruyama, S., 1989. Boninites and high-Mg andesites: tectonics and petrogenesis. In Crawford, A. J. (Ed.), Boninites and Related Rocks: London (Unwin Hyman), 112-147.

Taylor, R. N., and Nesbitt, R. W., 1988. Light rare-earth enrichment of supra-subduction zone mantle: evidence from the Troodos ophiolite, $\mathrm{Cy}$ prus. Geology, 16:448-451.

Taylor, R. N., Lapierre, H., Vidal, P., Nesbitt, R. W., and Croudace, I. W., in press. Igneous geochemistry and petrogenesis of the Izu-Bonin forearc basin. In Taylor, B., Fujioka, K., et al., Proc. ODP Init. Repts., 126: College Station, TX (Ocean Drilling Program).

Taylor, B., Fujioka, K., Janecek, T., et al., 1990. Proc. ODP Init. Repts., 126: College Station, TX (Ocean Drilling Program).
Tokuyama, H., 1985. Dredged igneous rocks from the Amami Plateau. In Shiki, T. (Ed.), Geology of the Northern Philippine Sea: Tokyo (Tokai University Press), 50-56.

Tracey, J. L., Schlanger, S. O., Stark, J. T., and Doan, D. B., 1964. General geology of Guam. U.S. Geol. Surv. Prof. Pap., 403-A: 104 p.

Umino, S., 1985. Volcanic geology of Chichijima, the Bonin Islands (Ogasawara Islands). J. Geol. Soc. Japan, 91:505-523.

Uyeda, S., and Ben-Avraham, Z., 1972. Origin and development of the Philippine Sea. Nature, 240:176-178.

van der Laan, S. R., 1987. An experimental study of boninite genesis. [PhD dissert.] (University of Illinois at Chicago). 103 p.

van der Laan, S. R., Flower, M.F.J., and van Groos, A.F.K., 1989. Experimental evidence for the origin of boninites: near-liquidus phase relations to 7.5 kbar. In Crawford, A. J. (Ed.), Boninites and Related Rocks: London (Unwin Hyman), 112-147.

Watson, E. B., and Harrison, T. M., 1984. Accessory minerals and the geochemical evolution of crustal magmatic systems: a summary and prospectus of experimental approaches. Phys. Earth Planet. Interiors, 35:19-30.

Watts, A. B., Weissel, J. R., and Larson, R. L., 1976. Sea-floor spreading in marginal basins of the western Pacific. Tectonophysics, 37:169-181.

Wolf, M. B., and Wyllie, P. J., in press. Dehydration-melting of solid amphibolite at $10 \mathrm{kbar}$ : textural development, liquid interconnectivity and applications to the segregation of magmas. Contrib. Mineral. Petrol.

Woodhead, J. D., 1989. Geochemistry of the Mariana arc (western Pacific): source composition and processes. Chem. Geol., 76:1-24.

Wyllie, P. J., 1977. Crustal anatexis: an experimental review. Tectonophysics, 43:41-71.

Yumul, G. P., Jr., 1990. Multi-stage melting, evolving mantle sources and ophiolite generation: constraints from the Zambales ophiolite complex, Philippines. [Ph.D. dissert.] Geological Institute, University of Tokyo.

\section{Date of initial receipt: 22 February 1991 \\ Date of acceptance: 18 November 1991 \\ Ms 125B-172}

\section{APPENDIX: TRACE ELEMENT BEHAVIOR DURING PARTIAL FUSION OF THE SUBDUCTED SLAB}

\section{Composition of the Subducted Slab}

The metamorphic structure of oceanic lithosphere prior to subduction is well known from ophiolite studies and deep drilling of the oceanic lithosphere as comprising, for metabasalts, brownstone facies, followed by zeolite facies, greenschist facies and amphibolite facies, meta-ultrabasic rocks being serpentinized up to lower amphibolite facies (Cann, 1979).

The net effect is that altered oceanic crust contains significantly more water, carbon dioxide, sulfur, and alkali and alkaline earth elements than average fresh MORB. The precise degree of enrichment of these elements will depend on, among other things, the age of the crust. There have been various estimates of the distribution of water within the crust. Peacock (1990), in one of the most recent reviews, estimated $2 \%$ water in the basalts and $1 \%$ in the gabbros.

Much of this water may be expelled from the crust during subduction and before melting. Delaney and Helgeson (1978) examined the thermodynamics of many of the possible dehydration reactions in sediment and serpentinite associated with subduction. They did not, however, consider the most important reactions for the dehydration of oceanic crust, which involves chlorite breakdown and hornblende formation. Hydrothermal experiments at the quartz-fayalite-magnetite (QFM) buffer by Liou et al. (1974) show that the transformation from greenschist to amphibolite facies is transitional. At $475^{\circ} \mathrm{C}$, chlorite begins to disappear, but total disappearance of chlorite and formation of a hornblende-plagioclase assemblage is not complete until $550^{\circ} \mathrm{C}$ at $2 \mathrm{~kb}$ and $575^{\circ} \mathrm{C}$ at $5 \mathrm{~kb}$. A generalized reaction for the chlorite-decreasing curve is: 
albite + epidote + chlorite + quartz $=$ oligoclase + tschermakite + magnetite $+\mathrm{H}_{2} \mathrm{O}$,

and for the chlorite-out boundary at $2 \mathrm{~kb}$ :

$$
\begin{gathered}
\text { chlorite }+ \text { sphene }+ \text { quartz }=\text { aluminous amphibole }+ \\
\text { ilmenite }+\mathrm{H}_{2} \mathrm{O}
\end{gathered}
$$

In terms of trace elements, the latter reaction should cause the high field strength (HFS) and large-ion lithophile (LIL) elements to be retained in the slab, as they are more compatible with the products of the reaction. Many highly mobile elements must, however, be released in the formation of greenschist facies from zeolite facies assemblages. We assume here that the upper oceanic crust is of altered MORB composition and that metamorphism up to amphibolite facies has not affected the elements of interest, particularly $\mathrm{La}, \mathrm{Sm}, \mathrm{Zr}$, and $\mathrm{Hf}$.

\section{Parameterization of Slab Melting}

Three end-member options have to be considered, each of which gives a distinctly different melting history:

$$
\begin{aligned}
& \mathrm{p}_{\mathrm{tot}}=\mathrm{p}_{\mathrm{vol}}=\mathrm{p}_{\mathrm{H}_{2} \mathrm{O}} \\
& \mathrm{p}_{\mathrm{tot}}=\mathrm{p}_{\mathrm{vol}}>\mathrm{p}_{\mathrm{H}_{2} \mathrm{O}} \\
& \mathrm{p}_{\mathrm{tot}} \mathrm{p}_{\mathrm{vol}}=>\mathrm{p}_{\mathrm{H}_{2} \mathrm{O}}
\end{aligned}
$$

Here, we parameterize the first option $\left(\mathrm{p}_{\mathrm{tot}}=\mathrm{p}_{\mathrm{vol}}=\mathrm{p}_{\mathrm{H}, \mathrm{O}}\right)$, using the experiments of Helz $(1973,1976)$. The tholeiites used by Helz in her experiments (a Picture Gorge tholeiite and the 1921 Kilauea olivine tholeiite) are close in composition to an evolved and primitive altered Pacific MORB, respectively. The pressure of $5 \mathrm{~kb}$ is within the range postulated for boninite genesis, although the oxygen fugacity, on the QFM buffer, may be slightly high. The principal results, summarized in Figure A1, show that melting starts in the region of $700^{\circ} \mathrm{C}$ and that feldspar and quartz make the dominant contribution to the melt up to the disappearance of plagioclase and start of incongruent melting of hornblende at $850^{\circ} \mathrm{C}-875^{\circ} \mathrm{C}$. They also reveal that the silica content of the melt decreases steadily with increasing temperature.

We parameterize the second option $\left(\mathrm{p}_{\mathrm{tot}}=\mathrm{p}_{\mathrm{vol}}>\mathrm{p}_{\mathrm{HO}}\right)$ on the basis of the experiments of Holloway and Burnham (1972), who used mixed vapor phases $\left(\mathrm{H}_{2} \mathrm{O}\right.$ and $\left.\mathrm{CO}_{2}\right)$ to control equilibrium water pressures. Holloway and Burnham also used the 1921 Kilauea olivine tholeiite for their experiments, and both NNO and QFM buffers, and at total pressures of 5 and $8 \mathrm{~kb}$, again within the likely range for boninite genesis. The principal results, also summarized in Figure A1, are that both the solidus and the upper stability limit of plagioclase are raised relative to the pure water experiments performed by Helz. Allen and Boettcher (1978) extended the work on the Kilauea tholeiite to higher pressure $(13 \mathrm{~kb})$ and variable $\mathrm{X}_{\mathrm{H}_{0}}$ values, though for a different (HM) buffer.

Parameterization of the third option $\left(\mathrm{p}_{\mathrm{tot}} \mathrm{p}_{\mathrm{vol}}=>\mathrm{p}_{\mathrm{H}, \mathrm{O}}\right.$ is more difficult because of a lack of controlled experiments for which the composition and proportion of the melt had been measured for a given temperature. ${ }^{7}$ The phase diagram used here is the schematic diagram of Wyllie (1977) for an amphibolite containing $0.5 \%$ to $1 \% \mathrm{H}_{2} \mathrm{O}$, the exact amount of water required to produce an amphibole-plagioclase assemblage (i.e., just enough to hydrate the rock). In this case, melting begins when the amphibole begins to break down, at a temperature

${ }^{7}$ Several articles have been published or made available to the authors since this chapter was prepared (e.g., Beard and Lofgren, 1991; Wolf and Wyllie, in press). These will improve the models presented here but do not negate the main conclusions.
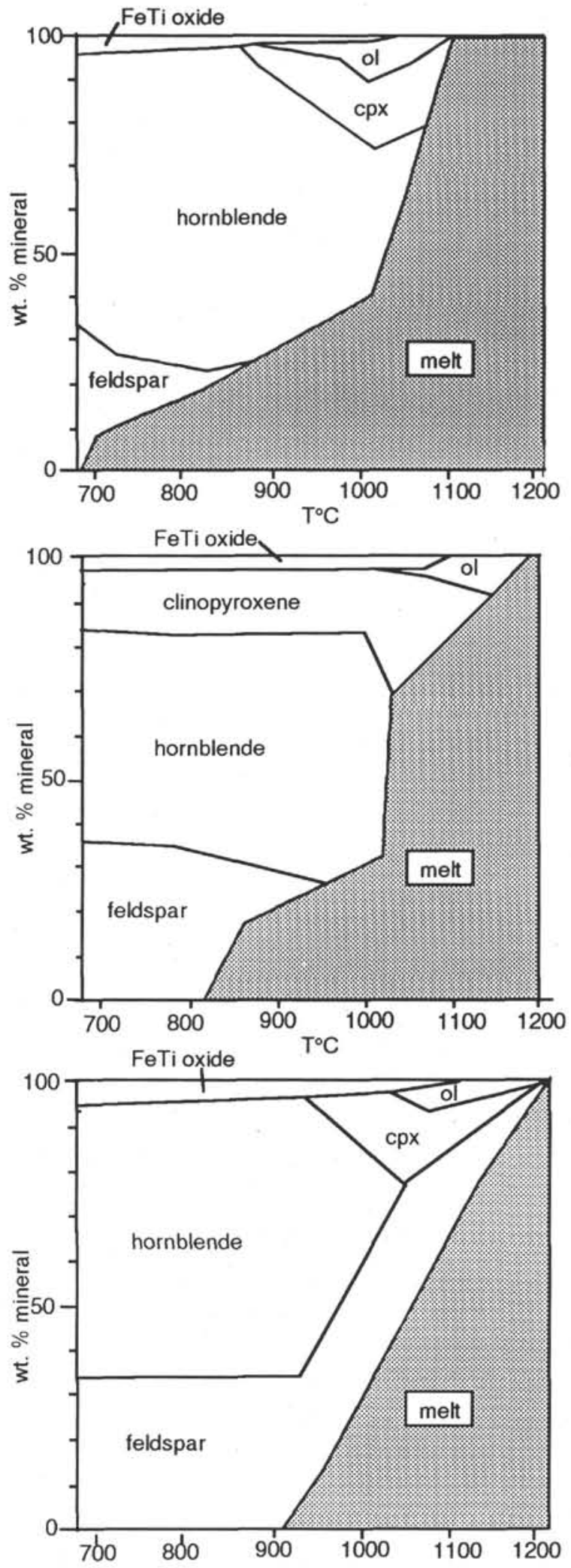

$\mathrm{T}^{\circ} \mathrm{C}$

Figure A1. Phase proportions used in the parameterization of the melting of subducted oceanic crust in amphilobolite 


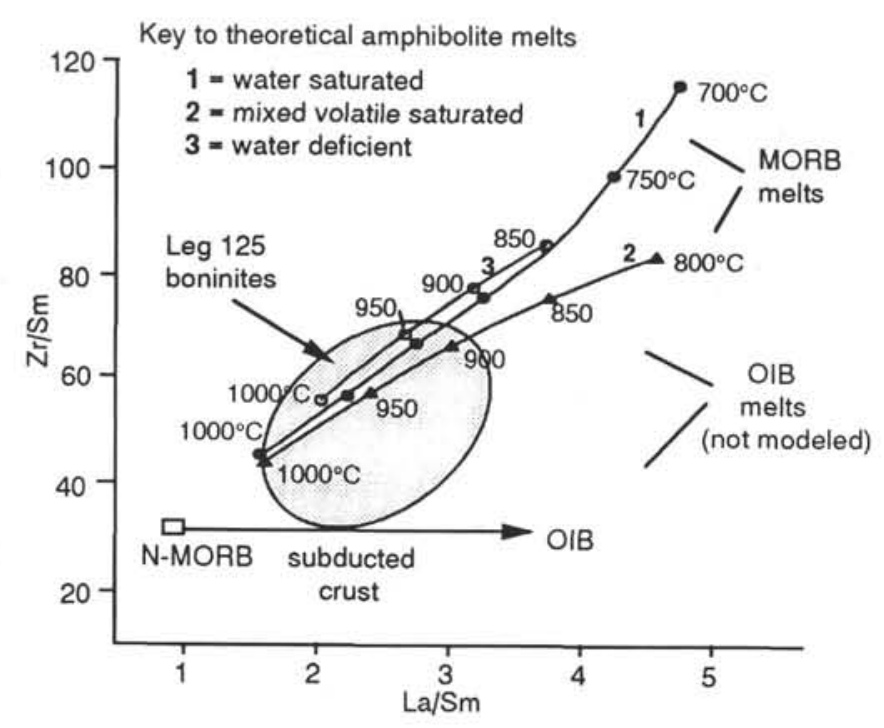

Figure A2. Results of modeling of MORB melting in amphibolite facies.

of over $900^{\circ} \mathrm{C}$ at $5 \mathrm{~kb}$ pressure. In contrast to the first two options, plagioclase remains in the residue up to high degrees of melting, and the early melts are less acid than in the other experiments. However, any quartz and potassium feldspar will combine with some plagioclase feldspar and contribute to the early melt fraction. In evaluating the melting of amphibolite of this composition, we assume that the degree of melting is linear with temperature and that each mole of hornblende will generate a mole of melt. While neither assumption is likely to hold, the aim at this stage is simply to get a broad understanding for the composition involved.

\section{Theoretical Amphibolite Melt Compositions}

Critical to the understanding of the composition of melts derived from the subducted slab under different P,T,X conditions are the partition coefficients between plagioclase, amphibole and the slab melt, and the role of minor phases. Because of the strong temperature-composition dependence of partition coefficients, and the general absence of experimental data, any values must be approximate. To simplify the discussion, we concentrate on the three elements, $\mathrm{La}$, $\mathrm{Sm}$, and $\mathrm{Zr}$ (assumed similar to $\mathrm{Hf}$ ). We also focus on intermediate to acid melts, as the degree of melting is unlikely to be high enough to generate basic melts. From the limited data available, it is not possible to determine the variation of partition coefficients in $\mathrm{P}-\mathrm{T}-\mathrm{X}$ space. The following regression lines are used to relate partition coefficient $(\mathrm{K})$ for a given element between amphibole and melt to absolute temperature (T) using compilations of Arth and Hanson (1975), Pearce and Norry (1979), and Irving (1978) and additional values from Dostal et al. (1983) and Irving and Frey (1984):

$$
\begin{array}{ll}
\text { For La: } \ln \mathrm{K} & =-6.43+6647 / \mathrm{T} \\
\text { For Sm: } \ln \mathrm{K} & =-4.85+6818 / \mathrm{T} \\
\text { For Zr: } \operatorname{lnK} & =-4.25+4879 / \mathrm{T}
\end{array}
$$

Errors on these values are high but do not affect the principal conclusions. Comparable equations for magnetite, clinopyroxene and plagioclase are also used, but these have little effect on the $\mathrm{La} / \mathrm{Sm}$ and $\mathrm{Zr} / \mathrm{Sm}$ ratios when modeling amphibolite melting.

The bulk distribution coefficient can, however, depend critically on the behavior of minor phases, particularly zircon, which accommodates $\mathrm{Zr}$ and $\mathrm{Hf}$ and monazite (or allanite), which accommodates the light REE. These are modeled by examining the relationships (from Watson and Harrison, 1984).

For zircon: $\ln \mathrm{C}_{\mathrm{Zr}}=17.18-12900 / \mathrm{T}$

For monazite: $\ln C_{\mathrm{LREE}}=18.50-14160 / \mathrm{T}$

where $\mathrm{C}$ refers to the saturation concentration of the subscripted element.

We model the concentrations of the three elements of interest from the mineral and melt proportions at different temperatures as determined from the melt parameterization described above. The modeling is based on the batch equilibrium melting equation assuming that the resulting composition will approximate that of pooled fractional melts. The source is taken to be an average N-MORB. Significantly, neither Zr or LREE is saturated in the melt generated from partial melting, essentially because the residual amphibole retains enough of these elements to inhibit saturation even at low temperatures and water-saturated melting.

Figure A2 summarizes the resulting $\mathrm{La} / \mathrm{Sm}$ and $\mathrm{Zr} / \mathrm{Sm}$ ratios for the three types of melting. It is apparent that amphibolite melting can explain the high $\mathrm{La} / \mathrm{Sm}$ and $\mathrm{Zr} / \mathrm{Sm}$ ratios observed in some boninites, although it need not, of course be the only explanation. The predicted melts occupy a band of variable enrichment in both $\mathrm{La} / \mathrm{Sm}$ and $\mathrm{Zr} / \mathrm{Sm}$, the highest ratios being the product of low-temperature melting. The water content does not have a major effect on either ratio, although the effect of water on partition coefficients has not been taken into account. Note, however, that the nature of the amphibolite protolith is important. Melts derived from ocean island basalt (IOB) protoliths will be displaced to the right on the diagram.

\section{Possible Observed Amphibolite Melt Compositions}

An alternative approach is to study the amphibolites themselves in paleo-subduction zones. The most comprehensive studies to date come from the Catalina schist within a blueschist-bearing subduction complex in Southern California (Sorensen and Barton, 1987; Sorensen, 1988; Sorensen and Grossman, 1989). The conditions of melting and metamorphism in the Catalina schist $\left(8-11 \mathrm{~kb}\right.$ and $640^{\circ} \mathrm{C}-$ $750^{\circ} \mathrm{C}$ ) are probably at higher pressure and lower temperature than we envisage at the initiation of subduction, and the presence of both metabasalts and metasediments in the Catalina schists is a complicating factor. However, many aspects of the studies of Sorensen and co-workers can be applied to the Pacific setting.

Of particular interest is the difference between their migmatitic and non-migmatitic amphibolites. The migmatites are significantly enriched in certain trace elements (e.g., Th, Ta, Hf, P, and the LREE) relative to the nonmigmatitic blocks. Sorensen and Grossmann (1989) interpret this enrichment in terms of infiltration metasomatism. Many trace elements are incorporated in the minor phases sphene, rutile, allanite, zircon, and apatite. Alternatively, the migmatites may represent metabasalt that experienced partial melting and lost a small melt fraction, thus concentrating some elements in these minerals in the residue (restite). The composition closest to our perception of a partial melt of amphibolite is trondhjemitic pegmatite. This rock type typically has large positive Eu anomalies and low REE contents with LREE enrichment and very high $\mathrm{Sr}$ contents. $\mathrm{Zr} / \mathrm{Sm}$ ratios can be high, but this is not always the case. At this stage, therefore, we do not fully understand the significance of this data set.

Pedersen and Malpas (1984) propose that the East-Karmøy plagiogranite of the Karmøy ophiolite may be a good example of wet basalt partial melt in amphibolite facies. Being highly sodic, this rock resembles ophiolitic plagiogranite derived by fractional crystallization, but it differs markedly in its trace element character. REE patterns in this rock type are steep; large positive $\mathrm{Eu}$ anomalies and $\mathrm{Zr} / \mathrm{Y}$ and $\mathrm{Zr} / \mathrm{Sm}$ ratios are both extremely high. In contrast to the trondhjemitic pegmatites from the Catalina schist, $\mathrm{Sr}$ is in surprisingly low abun- 
dance. Pedersen and Malpas (1984) suggest that the melting took place within a high-temperature shear zone.

Defant and Drummond (1990) and Drummond and Defant (in press) consider the generation of some trondhjemite, tonalite and dacite (TTD) associations in volcanic arcs by slab melting. They argue that the most fertile zone of melting is at $23-26 \mathrm{~kb}$ and $770^{\circ} \mathrm{C}-775^{\circ} \mathrm{C}$ where dehydration and wet partial melting of the slab can occur together. They require that these slab melts are generated in arcs where relatively young $(<30 \mathrm{Ma})$ and hot lithosphere is being subducted. These conditions are consistent with the theoretical thermal criteria for slab melting proposed by Peacock (1990). They term these rocks "adakites" after Adak Island (Alaska), where they were first documented by Kay (1978). In addition to this type example, they cite parts of Central and South America, where similar rocks erupt above young subducted lithosphere. They identify the principal characteristics of this rock type as silica $>=56 \%, \mathrm{Al}_{2} \mathrm{O}_{3}=15 \%, \mathrm{MgO}$ usually $<=3 \%$, high $\mathrm{Sr}$ (usually $>400 \mathrm{ppm}$ ), low HFS element abundances, and ${ }^{87} \mathrm{Sr} /{ }^{86} \mathrm{Sr}$ usually $<0.7040$. The Archaean TTD group is characterized by similar compositions (e.g., de Wit et al., 1987).

The "adakite" and TTD slab-melting components have $\mathrm{La} / \mathrm{Sm}$ and $\mathrm{Zr} / \mathrm{Y}$ ratios that are sufficiently high for the Leg 125 boninite sources. However, the $S \mathrm{~m} / \mathrm{Yb}$ ratios are too high, probably reflecting the presence of garnet in the residue, and $\mathrm{Zr} / \mathrm{Sm}$ ratios are too low, probably because the adakites are melts of eclogite rather than amphibolíte. Overall, therefore, the theoretical models may give the best representation of the slab component at the start of subduction. 